Prepared in cooperation with the U.S. ENVIRONMENTAL PROTECTION AGENCY

\title{
A Reconnaissance for Selected Herbicides, Metabolites, and Nutrients in Streams of Nine Midwestern States, 1994-95
}

By ELISABETH A. SCRIBNER, DONALD A. GOOLSBY, E. MICHAEL THURMAN, and WILLIAM A. BATTAGLIN

Open-File Report 98-181

Lawrence, Kansas 1998 


\section{U.S. Department of the Interior}

\section{Bruce Babbitt, Secretary}

\section{U.S. Geological Survey}

Thomas J. Casadevall, Acting Director

The use of firm, trade, and brand names in this report is for identification purposes only and does not constitute endorsement by the U.S. Geological Survey.

For additional information write to:

District Chief

U.S. Geological Survey

4821 Quail Crest Place

Lawrence, KS 66049-3839
Copies of this report can be purchased from:

U.S. Geological Survey

Information Services

Box 25286

Federal Center

Denver, CO 80225-0826 


\section{CONTENTS}

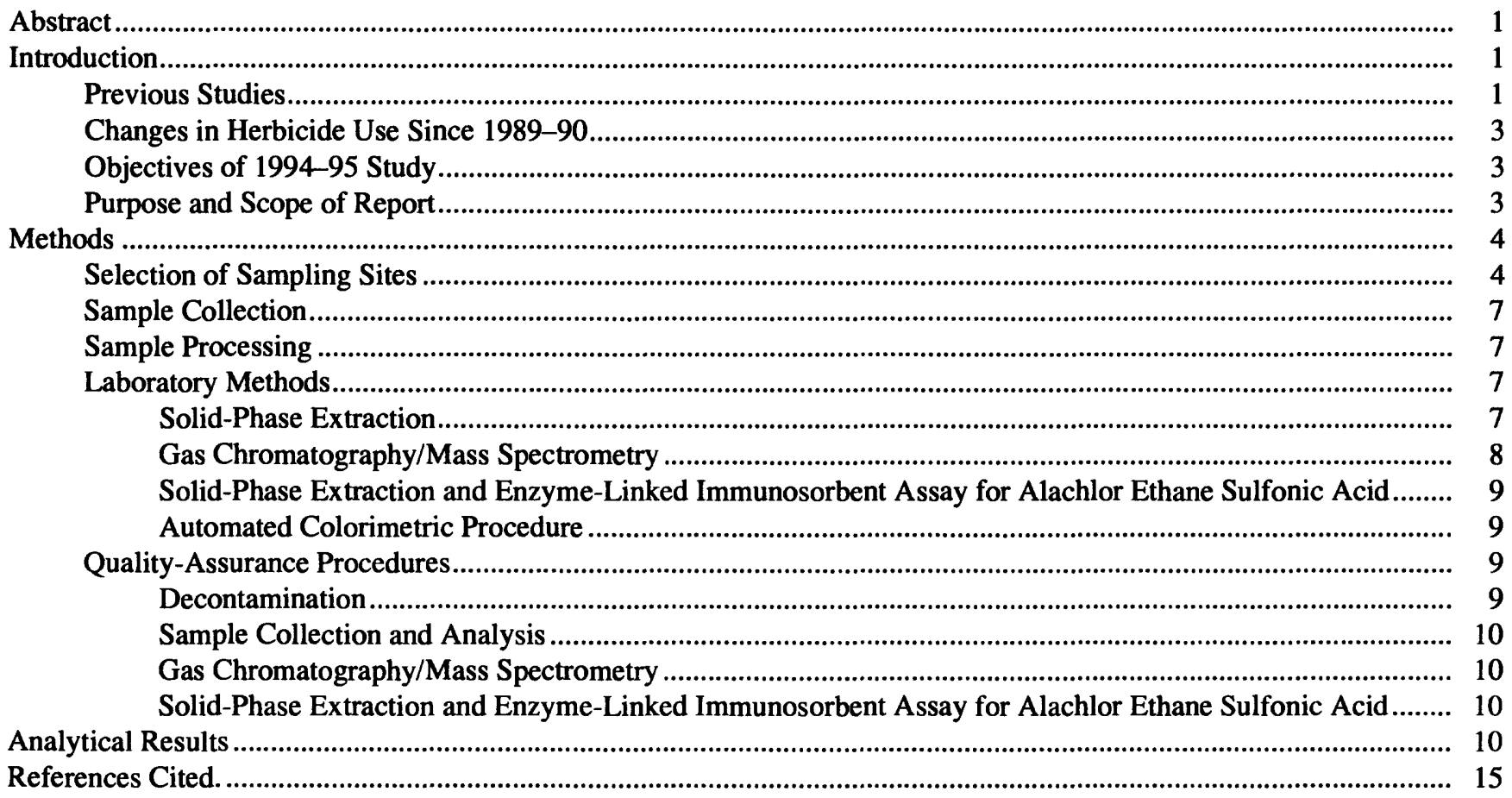

\section{FIGURES}

1. Map showing location of study area, stream sites, and associated contributing drainage areas sampled during 1994-95 in Midwestern United States

2-5. Graphs showing:

2. Herbicide use in Midwestern United States, 1963-95

3. Distribution of concentrations of detected herbicides and metabolites in water from 53 stream sites sampled during 1994 and 51 stream sites sampled during 1995 post-application sampling periods 16

4. Post-application distributions of acetochlor and alachlor in samples from 53 Midwestern streams, 1989-90 and 1994-95

5. Post-application distributions of atrazine and cyanazine in samples from 53 Midwestern streams, 1989-90 and 1994-95

\section{TABLES}

1. Sampling-site names, locations, and contributing drainage areas.

2. Method of determination or analysis and reporting limits for physical properties and chemical compounds in water samples from 53 streams in nine Midwestern States, 1994-95.

3. Concentrations of selected herbicides and three metabolites in quality-assurance samples from 53 streams in nine Midwestern States, 1994-95

4. Statistical summary of 1994 post-application herbicide and metabolite concentrations in water samples from 53 streams in nine Midwestern States

5. Statistical summary of 1995 post-application herbicide and metabolite concentrations in water samples from 51 streams in nine Midwestern States. 


\section{TABLES-Continued}

6. Analytical results for selected herbicides and six metabolites in water samples from 53 streams in nine Midwestern States, 1994-95

7. Streamflow, physical properties, and analytical results for dissolved nutrients in water samples from

53 streams in nine Midwestern States, 1994-95

CONVERSION FACTORS, MISCELLANEOUS

ABBREVIATIONS, AND ABBREVIATED WATER-

QUALITY UNITS

\begin{tabular}{rcl}
\hline Multiply & By & To obtain \\
\hline & & \\
cubic foot per second $\left(\mathrm{ft}^{3} / \mathrm{s}\right)$ & 0.02832 & cubic meter per second \\
mile $(\mathrm{mi})$ & 1.609 & kilometer \\
pound $(\mathrm{lb})$ & 453.6 & gram \\
pound per acre (lb/acre) & 1.121 & kilogram per hectare \\
square mile $\left(\mathrm{mi}^{2}\right)$ & 2.590 & square kilometer \\
\hline
\end{tabular}

Temperataure can be converted to degrees Celsius $\left({ }^{\circ} \mathrm{C}\right)$ or degrees Fahrenheit $\left({ }^{\circ} \mathrm{F}\right)$ by the equations:

$$
\begin{gathered}
{ }^{\circ} \mathrm{C}=5 / 9\left({ }^{\circ} \mathrm{F}-32\right) \\
{ }^{\circ} \mathrm{F}=9 / 5\left({ }^{\circ} \mathrm{C}\right)+32 .
\end{gathered}
$$

\section{Miscellaneous Abbreviations}

inside diameter (i.d.)

mass to charge $(\mathrm{m} / \mathrm{z})$

meter $(\mathrm{m})$

milliseconds per ion (ms/ion)

\section{Abbreviated Water-Quality Units}

kilopascal ( $\mathrm{kPa})$

microgram per liter $(\mu \mathrm{g} / \mathrm{L})$

microliter $(\mu \mathrm{L})$

micrometer $(\mu \mathrm{m})$

microsiemens per centimeter at 25 degrees Celsius $(\mu \mathrm{S} / \mathrm{cm})$

milligram per liter $(\mathrm{mg} / \mathrm{L})$

milliliter $(\mathrm{mL})$

milliliter per minute $(\mathrm{mL} / \mathrm{min})$

millimeter (mm)

nanogram (ng)

nanogram per microliter $(\mathrm{ng} / \mu \mathrm{L})$ 


\title{
A Reconnaissance For Selected Herbicides, Metabolites, and Nutrients in Streams of Nine Midwestern States, 1994-95
}

\author{
By Elisabeth A. Scribner, Donald A. Goolsby, E. Michael Thurman, and William A. Battaglin
}

\section{Abstract}

Water-quality data were collected from 53 Midwestern streams during 1994-95 as part of a study to determine if changes in herbicide use resulted in an overall decrease in herbicide concentrations since a previous reconnaissance study in 1989-90. This report includes a description of sampling-site selection, sample-collection and processing methods, laboratory methods, quality-assurance procedures, and a compilation of data on herbicide and nutrient concentrations. Sites were sampled in 1994 prior to application of herbicides in March or early April and during the first runoff period after application of herbicides. In 1995, sites were sampled during the first runoff period after the application of herbicides. Samples were analyzed for 13 herbicides, two atrazine metabolites, three cyanazine metabolites, and one alachlor metabolite. Samples also were analyzed for dissolved nutrients. These data have been useful in determining trends in herbicide concentrations in Midwestern streams and in determining the geographic distribution of alachlor, atrazine, and cyanazine metabolites.

\section{INTRODUCTION}

This is the sixth in a series of water-quality reports intended to present the analytical results from studies of herbicides and nutrients in water resources of the Midwestern United States. This report presents the analytical results from a study of 13 preemergent herbicides, two atrazine metabolites, three cyanazine metabolites, one alachlor metabolite, and dissolved nutrients in surface water of nine Midwestern States-Illinois, Indiana, Iowa, Kansas, Minnesota, Missouri, Nebraska, Ohio, and Wisconsin (fig. 1) during 1994-95. Previous reports have presented analytical results from regional studies of selected herbicides and dissolved nutrients in ground water (Kolpin and others, 1993), surface water (Scribner and others, 1993), storm runoff (Scribner and others, 1994), precipitation (Goolsby and others, 1995), and reservoirs (Scribner and others, 1996). This study was conducted by the U.S. Geological Survey (USGS) as part of the Toxic Substances Hydrology Program and in cooperation with the U.S. Environmental Protection Agency (USEPA).

\section{Previous Studies}

During 1989, the U.S. Geological Survey (USGS) conducted a reconnaissance study of 147 streams in 10 Midwestern States (those shown in fig. 1 plus South Dakota) to determine the geographic and seasonal distribution of herbicides and nutrients (Scribner and others, 1993). The streams were sampled before application of herbicides, during the first major runoff period after application of herbicides, and during a low-flow period in the fall when most of the streamflow was derived from ground water. Results from the 1989 study showed that large amounts of alachlor, atrazine, cyanazine, and metolachlor were flushed into streams during the first post-application runoff (Thurman and others, 1991, 1992; Battaglin and others, 1993; 


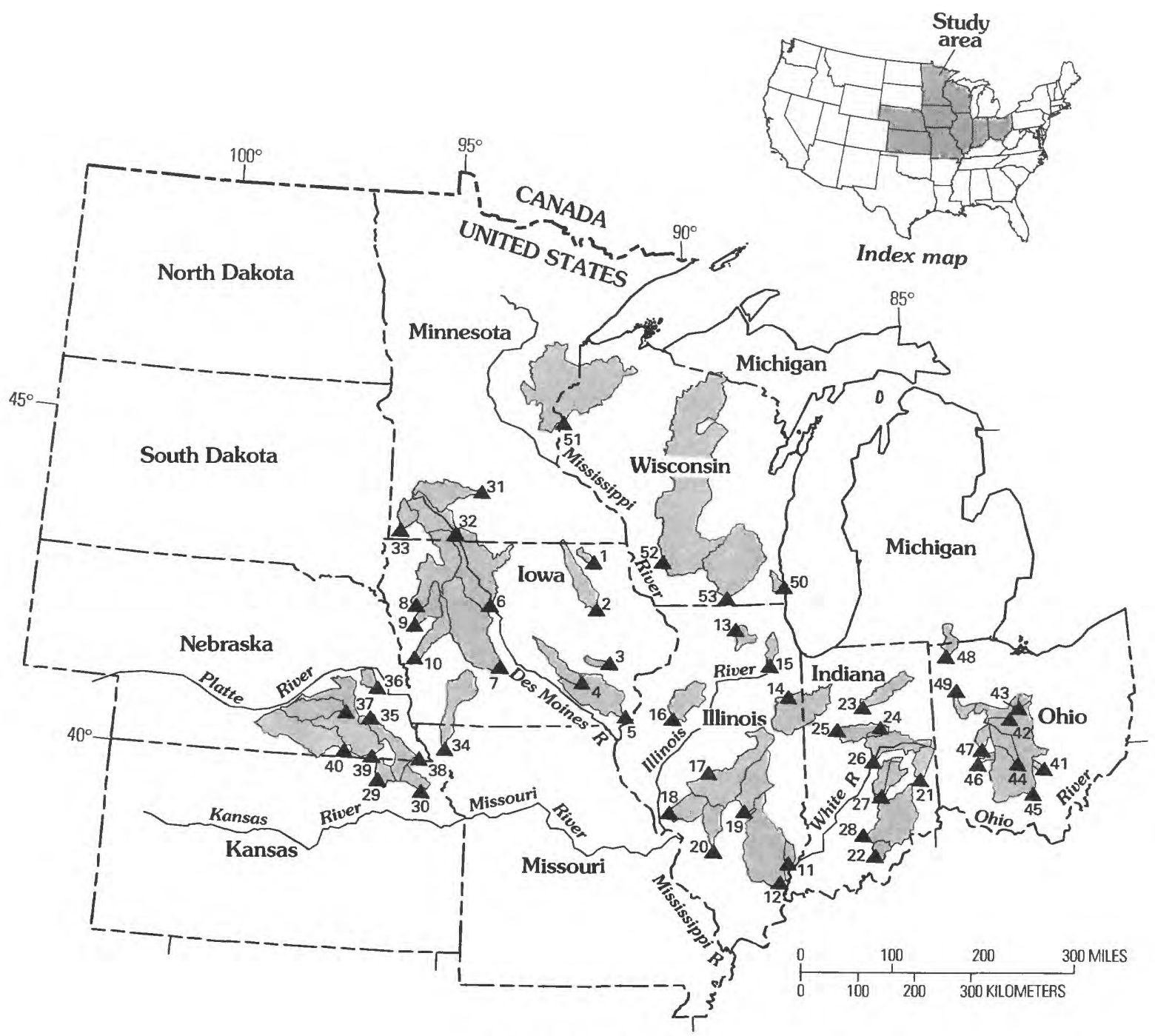

EXPLANATION

Sampling site and associated contributing drainage

basin-Number corresponds to map number used in tables

Figure 1. Location of study area, stream sites, and associated contributing drainage areas sampled during 1994-95 in Midwestern United States.

Goolsby and Battaglin, 1993; Goolsby and others, 1993). The maximum concentrations of alachlor, atrazine, and cyanazine exceeded $50 \mu \mathrm{g} / \mathrm{L}$, and the maximum concentration of metolachlor exceeded $39 \mu \mathrm{g} / \mathrm{L}$ during the post-application period. Maximum herbicide concentrations were less than $5 \mu \mathrm{g} / \mathrm{L}$, and most concentrations were less than $1 \mu \mathrm{g} / \mathrm{L}$ during the pre-application and fall low-flow sampling periods; however, more than one-half of the streams had detect- able concentrations during all three sampling periods. Both atrazine and cyanazine concentrations temporarily exceeded drinking-water regulations in about one-half of the streams (Thurman and others, 1991, 1992; Goolsby and others, 1994). The atrazine Maximum Contaminant Level (MCL) for drinking water established by USEPA is $3 \mu \mathrm{g} / \mathrm{L}$, and the cyanazine health advisory (HA) is $1 \mu \mathrm{g} / \mathrm{L}$ (U.S. Environmental Protection Agency, 1992). It should be 
noted, however, that there is no violation of the Safe Drinking Water Act unless the annual average concentration exceeds the MCL, or unless an individual concentration exceeds four times the MCL.

The 1989 reconnaissance study documented the geographic and seasonal distribution of herbicides in streams at a regional scale. A follow-up study was conducted by USGS in 1990 because of increased concern about the findings of high post-application concentrations of herbicides. The distributions of the concentrations of the major herbicides detected in 50 streams were essentially the same for both years for the pre- and post-application periods (Goolsby and others, 1991). These results and those of other studies (Wauchope, 1978; Frank and others, 1982; Leonard, 1988; Snow and Spalding, 1988; Baker and Richards, 1989) further indicated that the flush of herbicides following application is an annual occurrence. Additional studies by USGS in 1990 and 1991 using automatic samplers (Thurman and others, 1992; Goolsby and Battaglin, 1993; Scribner and others, 1994) showed that the herbicide flush lasts for several weeks to several months following application. By late summer, herbicide concentrations generally decrease to low concentrations (less than $0.50 \mu \mathrm{g} / \mathrm{L}$ ) and remain low until the process is repeated the following year.

\section{Changes in Herbicide Use Since 1989-90}

Since the 1989-90 regional-scale studies were conducted, two decreases have occurred in the maximum application rate of atrazine recommended on the manufacturers' labels. In 1990, the manufacturers of atrazine voluntarily reduced the maximum recommended application rate for atrazine to $3 \mathrm{lb}$ active ingredient per acre per year for corn and sorghum (USEPA, written commun., Jan. 23, 1990). Prior to this, the recommended maximum application rate was $4 \mathrm{lb}$ active ingredient per acre per year. The 1990 label change also restricted noncropland uses of atrazine to a maximum of $10 \mathrm{lb}$ active ingredient per acre per year. This label change occurred because of concern about ground-water contamination and applied to all products released for shipment after September 1, 1990.

In 1992, the manufacturers of atrazine further voluntarily reduced the maximum recommended application rate of atrazine on corn and sorghum to a range of 1.6 to $2.5 \mathrm{lb}$ active ingredient per acre per year depending on soil organic residue and erosion potential. As much as $0.50 \mathrm{lb}$ active ingredient per acre per year can be used in subsequent applications (USEPA, written commun., March 8, 1993). The total of all applications cannot exceed $2.5 \mathrm{lb}$ active ingredient per acre per year. A maximum of $1.6 \mathrm{lb}$ active ingredient per acre per year is recommended on soil with less than 30-percent plant residue remaining on the surface. Most noncropland uses of atrazine are no longer recommended on manufacturers' labels. This label change applied to all products shipped for use after August 1, 1992.

As a result of the two voluntary label changes, the maximum recommended application rate for atrazine on corn and sorghum essentially has been reduced by 50 percent since the 1989-90 studies were conducted. However, atrazine typically has not been applied at the maximum recommended rate. The actual application rate for atrazine decreased about 10 percent from an average of $1.22 \mathrm{lb} /$ acre in 1990 to 1.07 to $1.1 \mathrm{lb} /$ acre in 1994-95 (U.S. Department of Agriculture, 1991, 1994, 1995). The total use of atrazine decreased about 10 percent between 1989-90 and 1994-95.

The long-term use history, from 1963 through 1995 , of atrazine and four other major herbicides is shown in figure 2. The use of alachlor decreased from about 50 million lb in 1989-90 to 27 million lb in 1994 and to 12.6 million $\mathrm{lb}$ in 1995 . A new herbicide, acetochlor, was introduced in 1994. About 7 million $\mathrm{lb}$ of acetochlor were used in 1994. In 1995, acetochlor use had increased to about 23 million $\mathrm{lb}$. The overall use of cyanazine increased slightly between 1989-90 and 1994-95. The use of metolachlor changed very little between 1989-90 and 1994-95 (fig. 2).

\section{Objectives of 1994-95 Study}

The principal objective of the 1994-95 study was to determine if changes in the application rate recommended by the manufacturers of atrazine have resulted in an overall decrease in atrazine concentrations in Midwestern streams since 1989-90. Other objectives were to determine the geographic distribution of selected herbicide and metabolite concentrations in these streams.

\section{Purpose and Scope of Report}

The purpose of this report is to present results of analyses of 13 herbicides (acetochlor, alachlor, ametryn, atrazine, cyanazine, metolachlor, metribuzin, prometon, prometryn, propachlor, propazine, simazine, 


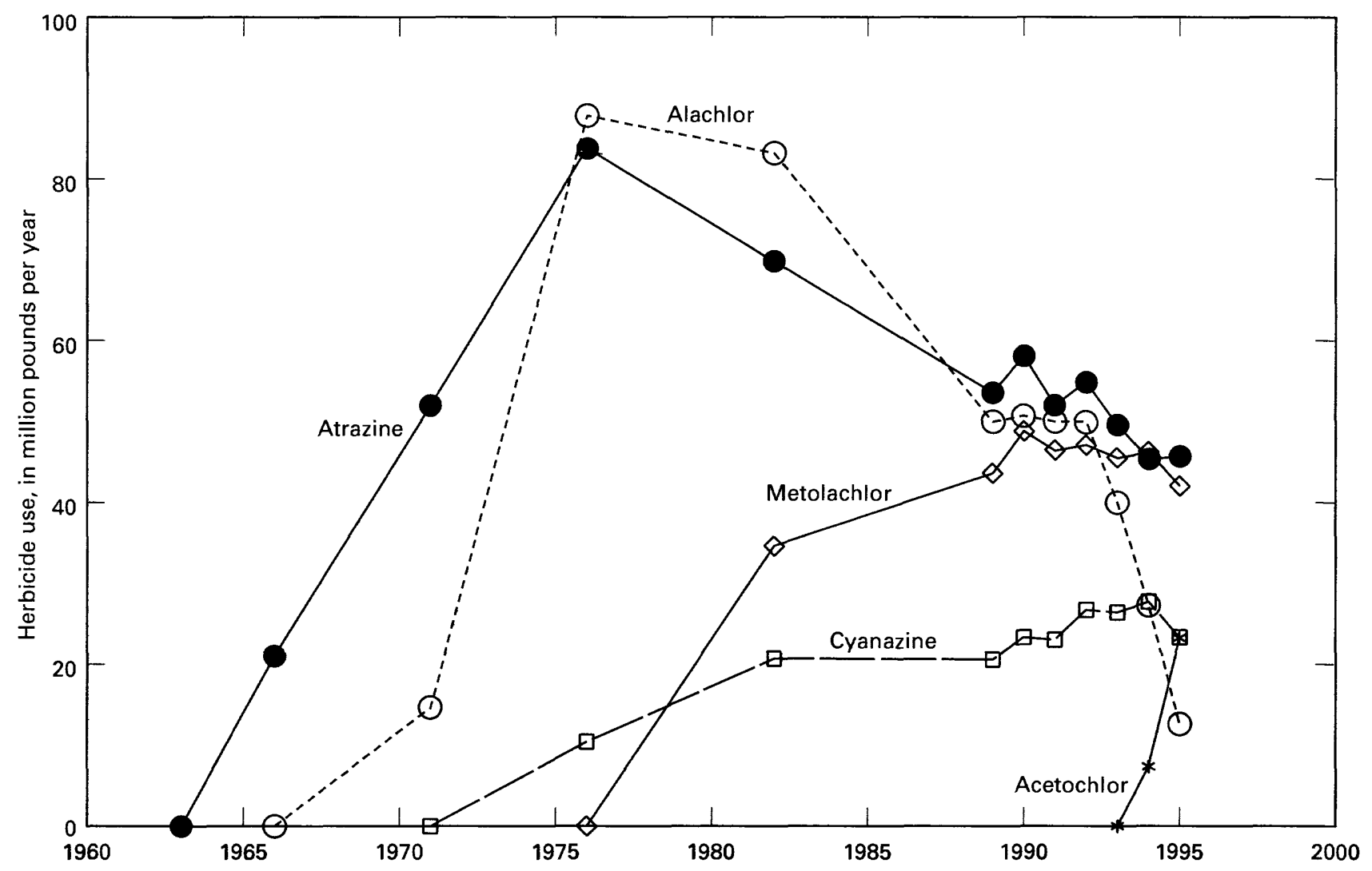

Figure 2. Herbicide use in Midwestern United States, 1963-95 (sources of data: 1964, Lin and others, 1995; 1966-89, Gianessi, 1992; 1990-95, U.S. Department of Agriculture, 1991, 1992, 1993, 1994, 1995).

and terbutryn), two atrazine metabolites (deethylatrazine and deisopropylatrazine), three cyanazine metabolites (cyanazine amide, deethylcyanazine, and deethylcyanazine amide), one alachlor metabolite (ethane sulfonic acid), and nutrients (nitrite as nitrogen, nitrite plus nitrate as nitrogen, ammonia as nitrogen, and orthophosphate as phosphorus) in water samples from 53 streams in nine Midwestern States during 1994-95. The study area includes all or parts of the following Midwestern States: Iowa, Illinois, Indiana, Kansas, Minnesota, Missouri, Nebraska, Ohio, and Wisconsin. This report also describes the selection of sampling sites, sample-collection and processing methods, laboratory methods, quality-assurance procedures, and gives a brief comparison of 1994-95 study results with 1989-90 results.

\section{METHODS}

\section{Selection of Sampling Sites}

Fifty-three stream sites were sampled during this study. Sampling-site names and locations are given in table 1, and the corresponding map locations are shown in figure 1. Also, included in table 1 is the contributing drainage area for each sampling site.

Fifty of the 53 sites were sampled in both 1989 and 1990. These 50 sites were selected by a statistical process from the 147 sites sampled during the post-planting period in 1989. This process included ranking the 147 sites from highest to lowest on the basis of total herbicide concentrations and dividing them into three equal strata. From the strata containing the highest concentrations, 25 sites were randomly selected. Similarly, 13 sites were randomly selected from the middle-concentration strata, and 12 sites were randomly selected from the low-concentration strata. This selection process ensured both geographic distribution of sampling sites and ensured that sites with low and high herbicide concentrations would be selected on the basis 
Table 1. Sampling-site names, locations, and contributing drainage areas

\begin{tabular}{|c|c|c|c|c|c|}
\hline $\begin{array}{l}\text { Map no. } \\
\text { (fig. 1) }\end{array}$ & $\begin{array}{c}\text { Site } \\
\text { identifica- } \\
\text { tion no. }\end{array}$ & Site name & $\begin{array}{l}\text { Latitude } \\
\text { (degrees, } \\
\text { minutes, } \\
\text { seconds) }\end{array}$ & $\begin{array}{l}\text { Longitude } \\
\text { (degrees, } \\
\text { minutes, } \\
\text { seconds) }\end{array}$ & $\begin{array}{l}\text { Contributing } \\
\text { drainage area } \\
\text { (square miles) }\end{array}$ \\
\hline \multicolumn{6}{|c|}{ Iowa } \\
\hline 1 & 05411600 & Turkey River at Spillville & $43^{\circ} 12^{\prime} 28^{\prime \prime}$ & $91^{\circ} 56^{\prime} 56^{\prime \prime}$ & 177 \\
\hline 2 & 05421000 & Wapsipinicon River at Independence & $42^{\circ} 27^{\prime} 49^{\prime \prime}$ & $91^{\circ} 53^{\prime} 42^{\prime \prime}$ & 1,048 \\
\hline 3 & 05455100 & Old Mans Creek near Iowa City & $41^{\circ} 36^{\prime} 25^{\prime \prime}$ & $91^{\circ} 36^{\prime} 40^{\prime \prime}$ & 201 \\
\hline 4 & 05472500 & North Skunk River near Sigourney & $41^{\circ} 18^{\prime} 03^{\prime \prime}$ & $92^{\circ} 12^{\prime} 16^{\prime \prime}$ & 730 \\
\hline 5 & 05474000 & Skunk River at Augusta & $40^{\circ} 45^{\prime} 13^{\prime \prime}$ & $91^{\circ} 16^{\prime} 40^{\prime \prime}$ & 4,303 \\
\hline 6 & 05480500 & Des Moines River at Fort Dodge & $42^{\circ} 30^{\prime} 22^{\prime \prime}$ & $94^{\circ} 12^{\prime} 04^{\prime \prime}$ & 4,190 \\
\hline 7 & 05484500 & Raccoon River at Van Meter & $41^{\circ} 32^{\prime} 02^{\prime \prime}$ & $93^{\circ} 56^{\prime} 59^{\prime \prime}$ & 3,441 \\
\hline 8 & 06606600 & Little Sioux River at Correctionville & $42^{\circ} 28^{\prime} 20^{\prime \prime}$ & $95^{\circ} 47^{\prime} 49^{\prime \prime}$ & 2,500 \\
\hline 9 & 06607200 & Maple River at Mapleton & $42^{\circ} 09^{\prime} 28^{\prime \prime}$ & $95^{\circ} 48^{\prime} 27^{\prime \prime}$ & 669 \\
\hline 10 & 06609500 & Boyer River at Logan & $41^{\circ} 38^{\prime} 33^{\prime \prime}$ & $95^{\circ} 46^{\prime} 57^{\prime \prime}$ & 871 \\
\hline \multicolumn{6}{|c|}{ Illinois } \\
\hline 11 & 03378000 & Bonpas Creek at Browns & $38^{\circ} 23^{\prime} 11^{\prime \prime}$ & $87^{0} 58^{\prime} 32^{\prime \prime}$ & 228 \\
\hline 12 & 03381495 & Little Wabash River at Carmi & $38^{\circ} 05^{\prime} 32^{\prime \prime}$ & $88^{\circ} 09^{\prime} 22^{\prime \prime}$ & 3,088 \\
\hline 13 & 05439500 & $\begin{array}{l}\text { South Branch Kishwaukee River at } \\
\text { Fairdale }\end{array}$ & $42^{\circ} 06^{\prime} 40^{\prime \prime}$ & $88^{\circ} 54^{\prime} 00^{\prime \prime}$ & 387 \\
\hline 14 & 05526000 & Iroquois River near Chebanese & $41^{\circ} 00^{\prime} 32^{\prime \prime}$ & $87^{\circ} 49^{\prime} 27^{\prime \prime}$ & 2,091 \\
\hline 15 & 05540500 & Dupage River near Shorwood & $41^{\circ} 31^{\prime} 20^{\prime \prime}$ & $88^{\circ} 11^{\prime} 35^{\prime \prime}$ & 324 \\
\hline 16 & 05569500 & Spoon River at London Mills & $40^{\circ} 42^{\prime} 32^{\prime \prime}$ & $90^{\circ} 16 ' 53^{\prime \prime}$ & 1,072 \\
\hline 17 & 05576500 & Sangamon River at Riverton & $39^{\circ} 50^{\prime} 34^{\prime \prime}$ & $89^{\circ} 32^{\prime} 52^{\prime \prime}$ & 2,618 \\
\hline 18 & 05587000 & Macoupin Creek near Kane & $39^{\circ} 14^{\prime} 03^{\prime \prime}$ & $90^{\circ} 23^{\prime} 40^{\prime \prime}$ & 868 \\
\hline 19 & 05592100 & Kaskaskia River near Cowden & $39^{\circ} 13^{\prime} 50^{\prime \prime}$ & $88^{\circ} 50^{\prime} 33^{\prime \prime}$ & 1,330 \\
\hline 20 & 05594000 & Shoal Creek near Breese & $38^{\circ} 36^{\prime} 35^{\prime \prime}$ & $89^{\circ} 29^{\prime} 40^{\prime \prime}$ & 735 \\
\hline \multicolumn{6}{|c|}{ Indiana } \\
\hline 21 & 03275000 & Whitewater River near.Alpine & $39^{\circ} 34^{\prime} 46^{\prime \prime}$ & $85^{\circ} 09^{\prime} 29^{\prime \prime}$ & 522 \\
\hline 22 & 03302800 & Blue River at Fredricksburg & $38^{\circ} 26^{\prime} 02^{\prime \prime}$ & $85^{\circ} 11^{\prime} 31^{\prime \prime}$ & 283 \\
\hline 23 & 03328500 & Eel River near Logansport & $40^{\circ} 46^{\prime} 55^{\prime \prime}$ & $86^{\circ} 15^{\prime} 50^{\prime \prime}$ & 789 \\
\hline 24 & 03333450 & Wildcat Creek near Jerome & $40^{\circ} 26^{\prime} 29^{\prime \prime}$ & $85^{\circ} 55^{\prime} 08^{\prime \prime}$ & 146 \\
\hline 25 & 03335000 & Wildcat Creek near Lafayette & $40^{\circ} 26^{\prime} 26^{\prime \prime}$ & $86^{\circ} 49^{\prime} 45^{\prime \prime}$ & 794 \\
\hline 26 & 03351000 & White River near Nora & $39^{\circ} 54^{\prime} 35^{\prime \prime}$ & $86^{\circ} 06^{\prime} 20^{\prime \prime}$ & 1,219 \\
\hline 27 & 03362500 & Sugar Creek near Edinburgh & $39^{\circ} 21^{\prime} 39^{\prime \prime}$ & $85^{\circ} 59^{\prime} 51^{\prime \prime}$ & 474 \\
\hline 28 & 03371500 & East Fork White River near Bedford & $38^{\circ} 46^{\prime} 10^{\prime \prime}$ & $86^{\circ} 24^{\prime} 30^{\prime \prime}$ & 3,861 \\
\hline
\end{tabular}


Table 1. Sampling-site names, locations, and contributing drainage areas-Continued

\begin{tabular}{|c|c|c|c|c|c|}
\hline $\begin{array}{l}\text { Map no. } \\
\text { (fig. 1) }\end{array}$ & $\begin{array}{c}\text { Site } \\
\text { identifica- } \\
\text { tion no. }\end{array}$ & Site name & $\begin{array}{l}\text { Latitude } \\
\text { (degrees, } \\
\text { minutes, } \\
\text { seconds) }\end{array}$ & $\begin{array}{l}\text { Longitude } \\
\text { (degrees, } \\
\text { minutes, } \\
\text { seconds) }\end{array}$ & $\begin{array}{l}\text { Contributing } \\
\text { drainage area } \\
\text { (square miles) }\end{array}$ \\
\hline \multicolumn{6}{|c|}{ Kansas } \\
\hline 29 & 06885500 & Black Vermillion River near Frankfort & $39^{\circ} 41^{\prime} 03^{\prime \prime}$ & $96^{\circ} 26^{\prime} 15^{\prime \prime}$ & 410 \\
\hline 30 & 06890100 & Delaware River near Muscotah & $39^{\circ} 31^{\prime} 17^{\prime \prime}$ & $95^{\circ} 31^{\prime} 57^{\prime \prime}$ & 431 \\
\hline \multicolumn{6}{|c|}{ Minnesota } \\
\hline 31 & 05317000 & Cottonwood River near New Ulm & $44^{\circ} 17^{\prime} 29^{\prime \prime}$ & $94^{\circ} 26^{\prime} 24^{\prime \prime}$ & 1,280 \\
\hline 32 & 05476000 & Des Moines River at Jackson & $43^{\circ} 37^{\prime} 10^{\prime \prime}$ & $94^{\circ} 59^{\prime} 10^{\prime \prime}$ & 1,220 \\
\hline 33 & 06483000 & Rock River at Luverne & $43^{\circ} 39^{\prime} 15^{\prime \prime}$ & $96^{\circ} 12^{\prime} 03^{\prime \prime}$ & 425 \\
\hline \multicolumn{6}{|c|}{ Missouri } \\
\hline 34 & 06817700 & Nodaway River near Graham & $40^{\circ} 12^{\prime} 08^{\prime \prime}$ & $95^{\circ} 04^{\prime} 07^{\prime \prime}$ & 1,320 \\
\hline \multicolumn{6}{|c|}{ Nebraska } \\
\hline 35 & 06803000 & Salt Creek at Roca & $40^{\circ} 39^{\prime} 29^{\prime \prime}$ & $96^{\circ} 39^{\prime} 55^{\prime \prime}$ & 167 \\
\hline 36 & 06804000 & Wahoo Creek at Itica & $41^{\circ} 08^{\prime} 40^{\prime \prime}$ & $96^{\circ} 32^{\prime} 10^{\prime \prime}$ & 271 \\
\hline 37 & 06880800 & $\begin{array}{l}\text { West Fork Big Blue River near } \\
\text { Dorchester }\end{array}$ & $40^{\circ} 43^{\prime} 52^{\prime \prime}$ & $97^{\circ} 10^{\prime} 38^{\prime \prime}$ & 1,206 \\
\hline 38 & 06815000 & Big Nemaha River at Fall City & $40^{\circ} 02^{\prime} 08^{\prime \prime}$ & $95^{\circ} 35^{\prime} 45^{\prime \prime}$ & 1,340 \\
\hline 39 & 06882000 & Big Blue River at Barneston & $40^{\circ} 02^{\prime} 40^{\prime \prime}$ & “96035'12" & 4,447 \\
\hline 40 & 06884000 & Little Blue River near Fairbury & $40^{\circ} 06^{\prime} 54^{\prime \prime}$ & “97 $97^{\circ} 10^{\prime} 13^{\prime \prime}$ & 2,350 \\
\hline \multicolumn{6}{|c|}{ Ohio } \\
\hline 41 & 03157000 & Clear Creek near Rockbridge & $39^{\circ} 35^{\prime} 18^{\prime \prime}$ & “82034'43" & 89 \\
\hline 42 & 03219500 & Scioto River near Prospect & $40^{\circ} 25^{\prime} 10^{\prime \prime}$ & “83ำ11'50" & 567 \\
\hline 43 & 03223000 & Olentangy River at Claridon & $40^{\circ} 34^{\prime} 58^{\prime \prime}$ & “82059'20" & 157 \\
\hline 44 & 03230500 & Big Darby Creek at Darbyville & $39^{\circ} 42^{\prime} 02^{\prime \prime}$ & “8306'37" & 534 \\
\hline 45 & 03234500 & Scioto River at Higby & $39^{\circ} 12^{\prime} 44^{\prime \prime}$ & "82051'50" & 5,131 \\
\hline 46 & 03240000 & Little Miami River near Oldtown & $39^{\circ} 44^{\prime} 54^{\prime \prime}$ & “8355'53" & 129 \\
\hline 47 & 03267900 & Mad River at Eagle City & $39^{\circ} 57^{\prime} 51^{\prime \prime}$ & “83ํำ'54" & 310 \\
\hline 48 & 04185000 & Tiffin River at Stryker & $41^{\circ} 30^{\prime} 16^{\prime \prime}$ & “84²5'47" & 410 \\
\hline 49 & 04186500 & Auglaize River near Fort Jennings & $40^{\circ} 56^{\prime} 55^{\prime \prime}$ & “84ำ15'58" & 332 \\
\hline \multicolumn{6}{|c|}{ Wisconsin } \\
\hline 50 & 04087240 & Root River at Racine & $42^{\circ} 45^{\prime} 05^{\prime \prime}$ & “87 $87^{\circ} 25^{\prime \prime}$ & 190 \\
\hline 51 & 05340500 & St. Croix River at St. Croix Falls & $45^{\circ} 24^{\prime} 25^{\prime \prime}$ & “92038'49" & 6,240 \\
\hline 52 & 05407000 & Wisconsin River at Muscoda & $43^{\circ} 11^{\prime} 54^{\prime \prime}$ & “9026'26" & 10,400 \\
\hline 53 & 05430500 & Rock River at Afton & $42^{\circ} 36^{\prime} 33^{\prime \prime}$ & “89004'14" & 3,340 \\
\hline
\end{tabular}


of past data. Three additional sites were sampled where automatic samplers were operated in 1990 to determine the temporal distribution of herbicides in several Midwestern streams (Scribner and others, 1994). These sites were also sampled in 1989. Thus, the 53 sites selected for this study had previously been sampled during pre- and post-application periods in both 1989 and 1990.

\section{Sample Collection}

All 53 sites were sampled twice in 1994. In 1995, 51 sites were sampled once. Two sites were not sampled because runoff did not occur. In 1994, the first sample was collected prior to the application of herbicides in March or early April. A second sample was collected after herbicides had been applied and following the first precipitation that produced overland flow (runoff). Attempts were made to collect the sample near the peak discharge during this runoff. Results and hydrographs from the 1989 sampling and studies using autosamplers in 1990 showed this was when the largest herbicide and nutrient concentrations occurred (Thurman and others, 1992).

Only one sample was collected at each site in 1995. This sample was collected after herbicides had been applied and following the first precipitation that produced overland flow. Attempts were made to collect the sample near the peak discharge during the runoff. At two sites, Old Mans Creek in Iowa (map no. 3, fig. 1) and Salt Creek in Nebraska (map no. 35, fig. 1), samples were collected several times throughout the spring and summer of 1995 to determine the temporal distribution of herbicides.

Water samples were collected with a depth-integrating technique at three or more locations across each stream (Ward and Harr, 1990). The water samples from each site were composited in a single glass container or Teflon bottle. Stream discharge was determined at each site by direct measurement (current meter), from a rating curve, or estimated from data collected at a nearby USGS streamflow-gaging station.

\section{Sample Processing}

Herbicide samples were withdrawn from the compositing container and filtered through a $0.70-\mu \mathrm{m}$ glass-fiber filter using a peristaltic pump. Nutrient samples were withdrawn and filtered through $0.45-\mu \mathrm{m}$ membrane filters. Filters were leached with about $200 \mathrm{~mL}$ of sample prior to filtration of herbicide or nutrient sample.

The filtrate for herbicide analysis was collected in four heat-cleaned $125-\mathrm{mL}$ amber glass bottles. The filtrate for nutrient analysis was collected in a $125-\mathrm{mL}$ amber polyethylene bottle. The remainder of the water in the compositing container was used for onsite measurements of specific conductance, $\mathrm{pH}$, and water temperature. All samples were chilled immediately and shipped to the appropriate laboratory within 3 days of collection. Herbicide samples were sent to the USGS laboratory in Lawrence, Kansas, for gas chromatography/mass spectrometry (GC/MS) and enzyme-linked immunosorbent assay (ELISA) analyses. Herbicide sample bottles received at the USGS laboratory in Lawrence, Kansas, were logged in, assigned identification numbers, and refrigerated at $4{ }^{\circ} \mathrm{C}$ until analyzed. Nutrient samples were shipped to the USGS laboratory in Arvada, Colorado, for analysis.

\section{Laboratory Methods}

Samples were analyzed for 13 herbicides, two atrazine metabolites, and three cyanazine metabolites by GC/MS according to procedures described by Thurman and others (1990), Meyer and others (1993), and Meyer (1994). Alachlor ESA was analyzed by the method of Aga and others (1994). Nutrient compounds were analyzed using the method described by Fishman and Friedman (1989). The methods of analysis and reporting limits for physical properties and chemical compounds are listed in table 2.

\section{Solid-Phase Extraction}

Analytes for GC/MS analysis were extracted and concentrated using solid-phase extraction. An automated procedure (Meyer and others, 1993) using a Waters Millilab workstation and C18 Sep-Pak-Plus cartridges was used. Cartridges were preconditioned on the workstation sequentially with $2 \mathrm{~mL}$ distilled water, $6 \mathrm{~mL}$ ethyl acetate, $2 \mathrm{~mL}$ methanol, and $3 \mathrm{~mL}$ distilled water. Each 123-mL water sample was spiked with $100 \mu \mathrm{L}$ of a surrogate standard, terbuthylazine $(1.23 \mathrm{ng} / \mu \mathrm{L})$, and pumped through the cartridge at a rate of $20 \mathrm{~mL} / \mathrm{min}$ by the robotic system. Analytes were eluted from the cartridge with $3.5 \mathrm{~mL}$ ethyl acetate and spiked robotically with $100 \mathrm{ng}$ of phenanthrene- $d_{10}$. Samples with concentrations above the 
Table 2. Method of determination or analysis and reporting limits for physical properties and chemical compounds in water samples from 53 streams in nine Midwestern States, 1994-95

$\left[\mathrm{ft}^{3} / \mathrm{s}\right.$, cubic feet per second; $\mu \mathrm{S} / \mathrm{cm}$, microsiemens per centimeter at 25 degrees Celsius, ${ }^{\circ} \mathrm{C}$, degrees Celsius, $\mu \mathrm{g} / \mathrm{L}$, micrograms per liter; $\mathrm{mg} / \mathrm{L}$, milligrams per liter; SPE, solid-phase extraction; GC/MS, gas chromatography/mass spectrometry; ELISA, enzyme-linked immunosorbent assay; $N$, nitrogen; $P$, phosphorus]

\begin{tabular}{|c|c|c|}
\hline Property or compound & $\begin{array}{l}\text { Method of determination } \\
\text { or analysis }\end{array}$ & Reporting limit \\
\hline & Property & \\
\hline Streamflow & Current meter or rating curve & $0.01 \mathrm{ft}^{3} / \mathrm{s}$ \\
\hline Specific conductance & Conductance meter & $1 \mu \mathrm{S} / \mathrm{cm}$ \\
\hline pH & pH meter & .10 standard unit \\
\hline \multirow[t]{2}{*}{ Temperature, water } & Thermometer or thermister & $.10^{\circ} \mathrm{C}$ \\
\hline & Herbicides & \\
\hline acetochlor & SPE-GC/MS & $.05 \mu \mathrm{g} / \mathrm{L}$ \\
\hline alachlor & do. & do. \\
\hline ametryn & do. & do. \\
\hline atrazine & do. & do. \\
\hline cyanazine & do. & do. \\
\hline metolachlor & do. & do. \\
\hline metribuzin & do. & do. \\
\hline prometon & do. & do. \\
\hline prometryn & do. & do. \\
\hline propachlor & do. & do. \\
\hline propazine & do. & do. \\
\hline simazine & do. & do. \\
\hline \multirow[t]{2}{*}{ terbutryn } & do. & do. \\
\hline & rbicide metabolites & \\
\hline alachlor ethane sulfonic acid (ESA) & SPE-ELISA & $.10 \mu \mathrm{g} / \mathrm{L}$ \\
\hline cyanazine amide & SPE-GC/MS & $.05 \mu \mathrm{g} / \mathrm{L}$ \\
\hline deethylatrazine & do. & do. \\
\hline deethylcyanazine & do. & do. \\
\hline deethylcyanazine amide & do. & $.50 \mu \mathrm{g} / \mathrm{L}$ \\
\hline \multirow[t]{2}{*}{ deisopropylatrazine } & do. & $.05 \mu \mathrm{g} / \mathrm{L}$ \\
\hline & Nutrients & \\
\hline nitrite as $\mathbf{N}$ & colorimetric & $.01 \mathrm{mg} / \mathrm{L}$ \\
\hline nitrite plus nitrate as $\mathrm{N}$ & do. & $.05 \mathrm{mg} / \mathrm{L}$ \\
\hline ammonia as $\mathbf{N}$ & do. & $.01 \mathrm{mg} / \mathrm{L}$ \\
\hline orthophosphate as $\mathbf{P}$ & do. & do. \\
\hline
\end{tabular}

linear range, $10 \mu \mathrm{g} / \mathrm{L}$, were diluted, reextracted, and reanalyzed. The ethyl acetate layer was transferred by probe to a clean test tube. The robotic probe was washed between samples by immersing in ethyl acetate and bubbling air through the probe to prevent sample cross contamination of herbicide samples and standards. Finally, the extract was evaporated to a volume of $100 \mu \mathrm{L}$ with a Turbovap evaporator at $45^{\circ} \mathrm{C}$ under a nitrogen stream. This was pipetted into a $100-\mu \mathrm{L}$ glass autosampler vial.

\section{Gas Chromatography/Mass Spectrometry}

Analyses were made for the 13 herbicides listed in table 2 as well as two atrazine metabolites, deethylatrazine and deisopropylatrazine. Automated GC/MS analyses of the sample extracts were performed on a Hewlett-Packard Model 5890 GC and a 5970A mass selective detector (MSD) in selected ion mode. Operating conditions were as follows: ionization voltage, 70 electronvolts; ion-source temperature, $280^{\circ} \mathrm{C}$; elec- 
tron multiplier, 400 volts over the autotune voltage; direct capillary interface at $280^{\circ} \mathrm{C}$, initial GC oven temperature, $60^{\circ} \mathrm{C}$, tuned daily with perfluorotributylamine; dwell time, 25 to $50 \mathrm{~ms} /$ ion. Separation of the herbicides was carried out using a Hewlett Packard fused-silica, Ultra-1, $12 \mathrm{~m}$ x $0.2 \mathrm{~mm}$ i.d., GC capillary column of methyl silicone film with a thickness of $0.33 \mu \mathrm{m}$. Helium was used as the carrier gas at a flow rate of $1 \mathrm{~mL} / \mathrm{min}$ and a head pressure of $35 \mathrm{kPa}$. The column temperature was held at $60^{\circ} \mathrm{C}$ for 1 minute and then ramped at $6{ }^{\circ} \mathrm{C}$ per minute to $250{ }^{\circ} \mathrm{C}$. Injector temperature was $280^{\circ} \mathrm{C}$.

Quantification was based on the area ratio of the base peaks relative to the response of the 188 ion of phenanthrene- $d_{10}$, the internal standard. Confirmation of the compound was based on the presence of the molecular ion and two confirming ions with a retention-time match of \pm 0.2 percent relative to phenanthrene- $d_{10}$. The quantitation limit for the compounds was $0.05 \mu \mathrm{g} / \mathrm{L}$. Concentrations were based on a standard curve developed from known standards in distilled water. Samples with concentrations above the linear range, $10 \mu \mathrm{g} / \mathrm{L}$, were diluted, reextracted, and finally reanalyzed. The preceding procedure is described in detail by Thurman and others (1990) and Meyer and others (1993).

For the separation of the cyanazine metabolites, cyanazine amide, deethylcyanazine, and deethylcyanazine amide, a Hewlett Packard Ultra-2, $12 \mathrm{~m}$ x $0.2 \mathrm{~mm}$, GC capillary column of methyl silicone with 5 -percent phenyl film was used. The GC/MS conditions for these analysis were the same as described previously except for the following: direct capillary interface at $210^{\circ} \mathrm{C}$, initial GC oven temperature, $140^{\circ} \mathrm{C}$; ramp rate, $15^{\circ} \mathrm{C}$ per minute to $250^{\circ} \mathrm{C}$. The quantitation limit for cyanazine amide and deethylcyanazine was $0.05 \mu \mathrm{g} / \mathrm{L}$ and for deethylcyanazine amide, $0.50 \mu \mathrm{g} / \mathrm{L}$. A dilution of the sample was used when necessary. This procedure is described in more detail by Meyer (1994).

\section{Solid-Phase Extraction and Enzyme-Linked Immunosorbent Assay for Alachlor Ethane Sulfonic Acid}

Alachlor ESA was analyzed by solid-phase extraction (SPE) and ELISA by the method described in Aga and others (1994). The SPE procedure was automated with a Waters Millilab workstation for extraction of the analyte. The $\mathrm{C}_{18}$ Sep-Pak cartridges were preconditioned sequentially with $2 \mathrm{~mL}$ methanol, $6 \mathrm{~mL}$ ethyl acetate, $2 \mathrm{~mL}$ methanol, and $2 \mathrm{~mL}$ distilled water. Each
100-mL water sample was passed through a cartridge at a flow rate of $20 \mathrm{~mL} / \mathrm{min}$. The cartridge was eluted first with $3.5 \mathrm{~mL}$ ethyl acetate to remove the parent compound alachlor. A second elution with $3.5 \mathrm{~mL}$ methanol to remove alachlor ESA was collected in a separate test tube. The methanol extracts were evaporated to dryness under nitrogen at $45^{\circ} \mathrm{C}$ using a Turbovap evaporator. The samples then were reconstituted with $10 \mathrm{~mL}$ of distilled water and analyzed using an alachlor immunoassay kit. The concentrations of alachlor ESA were calculated by the following equation (Brady, 1995):

$$
\operatorname{logit}(y)=\ln (y / 1-y)
$$

where $y=$ absorbance reading, which transformed data using alachlor ESA standards of 0, 1.0, 5.0, and $20 \mu \mathrm{g} / \mathrm{L}$ divided by the concentration factor from the SPE procedure. All samples were analyzed in duplicate. The reporting limit was $10 \mu \mathrm{g} / \mathrm{L}$.

\section{Automated Colorimetric Procedure}

Dissolved nitrite as nitrogen, nitrite plus nitrate as nitrogen, ammonia as nitrogen, and orthophosphate as phosphorus were determined by automated colorimetric procedures at the USGS laboratory in Arvada, Colorado, using methods described by Fishman and Friedman (1989).

\section{Quality-Assurance Procedures}

Quality-assurance procedures for this study were carried out by USGS personnel in accordance with a written work plan for the study (Goolsby and others, 1994). Sample collection, processing, and analytical procedures used in this study were identical to those used in the 1989-90 reconnaissance.

\section{Decontamination}

Onsite quality-assurance procedures required all sampling equipment to be cleaned by washing glass containers, filter units, and tubing with a nonphosphate detergent; rinsing sequentially with tap water, organic-free, deionized, or distilled water, and then methanol; and rinsing again with organic-free water to remove traces of methanol. Herbicide sample contain- 
ers (125-mL glass bottles) were cleaned by heating overnight to about $350^{\circ} \mathrm{C}$.

\section{Sample Collection and Analysis}

Quality-control samples consisted of blind replicates, blind spikes, field-equipment blanks, and laboratory duplicates. About 5 percent of the samples were blind replicates, and an additional 5 percent of the samples consisted of blind spikes and field-equipment blanks. In addition, about 10 percent of all herbicide samples were analyzed in duplicate at the laboratory in Lawrence, Kansas. Blind replicate samples for herbicide analysis were obtained during each sampling period. Replicates of regular samples were labeled with ficticious site information and submitted to the laboratory in Lawrence, Kansas, along with the regular samples for herbicide analysis. Results for the blind replicate analyses are included in table 6 at the end of this report.

Blind spikes for herbicide analysis were independently prepared by the USGS National Water-Quality Laboratory in Arvada, Colorado, and submitted with the regular samples. These samples consisted of 125 -mL bottles filled with solutions of known herbicide concentrations. They were labeled as stream samples and sent to the laboratory in Lawrence, Kansas. Results for spike samples analyzed during the sampling rounds are shown in table 3 . There were no significant differences between the recoveries of the herbicides from the field spikes from 1989-90 to 1994-95.

Field-equipment blanks for herbicides were obtained on the first sample processed and about every 20th sample thereafter. Organic-free water was filtered into four $125-\mathrm{mL}$ baked amber glass bottles labeled as a field-equipment blank and shipped overnight to the laboratory in Lawrence, Kansas, along with the regular herbicide samples. There were no detections of any herbicide compounds in the 16 field-equipment blanks analyzed.

\section{Gas Chromatography/Mass Spectrometry}

For the GC/MS method, each water sample to be analyzed for herbicides and metabolites was spiked with a surrogate standard and terbuthylazine. An internal standard, phenanthrene- $d_{10}$, was added to the sample after it was extracted by SPE. The ratio of the terbuthylazine to the phenanthrene- $d_{10}$ in the final extract was used to calculate the percent recovery of the sample. Additional quality-assurance protocols consisted of 10 percent blank samples and 10 percent standard solutions for the sampling period. Results of the laboratory duplicate analyses are included in table 6 at the end of this report.

\section{Solid-Phase Extraction and Enzyme-Linked Immunosorbent Assay for Alachlor Ethane Sulfonic Acid}

For the alachlor ESA method, results were quantified with a new calibration curve prepared from standards run with each assay. Every ninth sample was extracted in duplicate, and all extracts were analyzed in duplicate and averaged.

\section{ANALYTICAL RESULTS}

A statistical summary of the concentrations of herbicide compounds measured in water samples from 53 streams for the 1994 post-application season is given in table 4. A summary of the 1995 results for samples from these same streams is given in table 5 . Two compounds, alachlor ESA and atrazine, were detected in all post-planting samples.

In 1994, 35 percent of the stream samples had alachlor concentrations exceeding the MCL for drinking water of $2 \mu \mathrm{g} / \mathrm{L}$ (U.S. Environmental Protection Agency, 1992) and 4 percent exceeded four times the MCL. Samples with herbicide concentrations more than four times the MCL may violate the Safe Drinking Water Act. In 1995, alachlor concentrations were considerably lower, with 8 percent of the stream samples exceeding the alachlor MCL of $2 \mu \mathrm{g} / \mathrm{L}$, and 2 percent exceeding four times the MCL. Both acetochlor and alachlor were detected in 82 percent of the stream samples in 1995, but the median acetochlor concentration $(0.42 \mu \mathrm{g} / \mathrm{L})$ was three times higher than the median alachlor concentration of $0.13 \mu \mathrm{g} / \mathrm{L}$.

Atrazine, with a median concentration of $4.2 \mu \mathrm{g} / \mathrm{L}$ in 1994, exceeded the MCL of $3 \mu \mathrm{g} / \mathrm{L}$ (U.S. Environmental Protection Agency, 1992) in 65 percent of the stream samples and four times the MCL in 20 percent of the samples. The median concentration for atrazine was $5.5 \mu \mathrm{g} / \mathrm{L}$ in 1995 , and concentrations exceeded the MCL of $3 \mu \mathrm{g} / \mathrm{L}$ in 60 percent of the stream samples and four times the MCL in 32 percent of the samples.

In 1994, cyanazine had a median concentration of $1.2 \mu \mathrm{g} / \mathrm{L}$, and 20 percent of the stream samples had concentrations exceeding four times the HA of $1.0 \mu \mathrm{g} / \mathrm{L}$ (U.S. Environmental Protection Agency, 


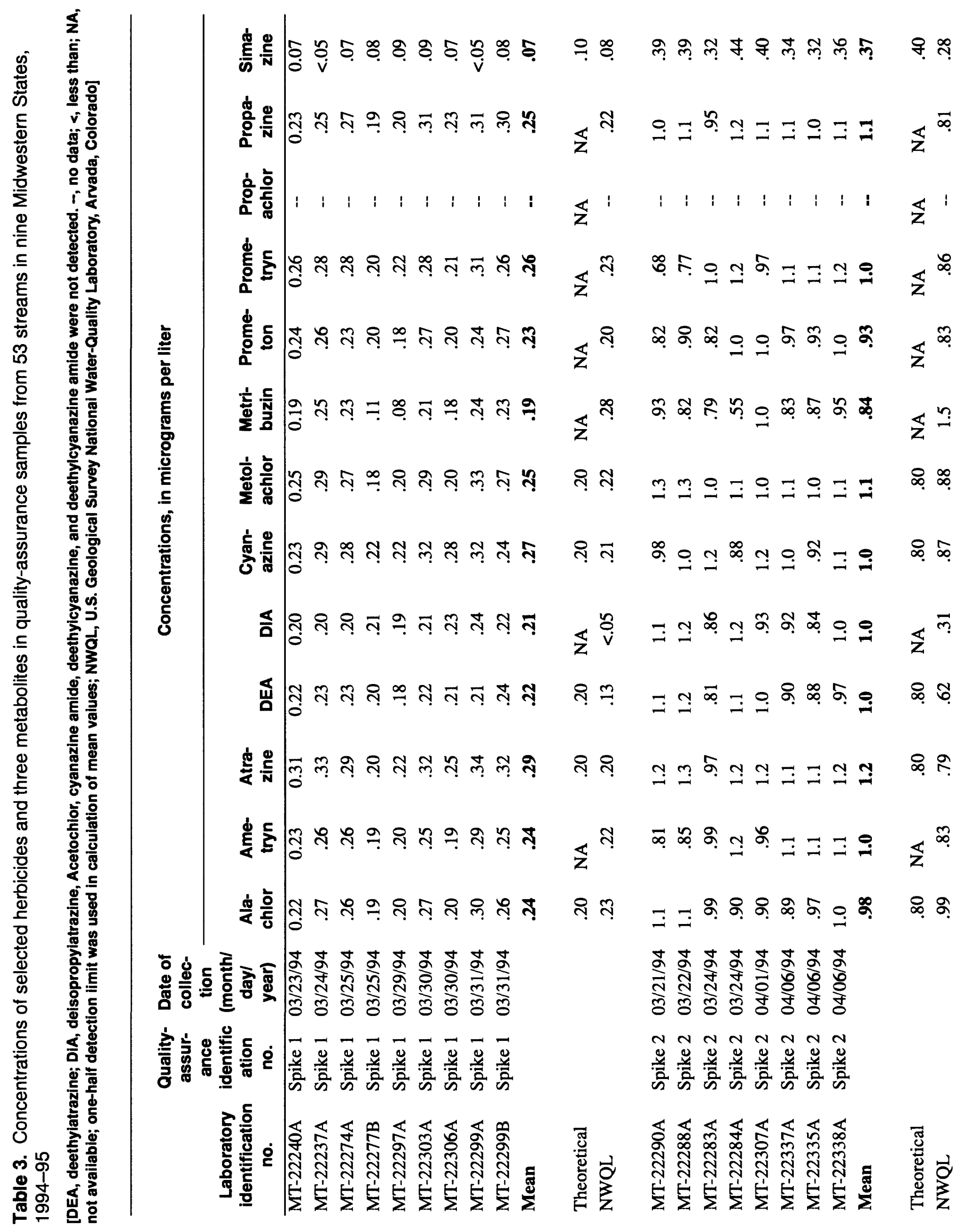




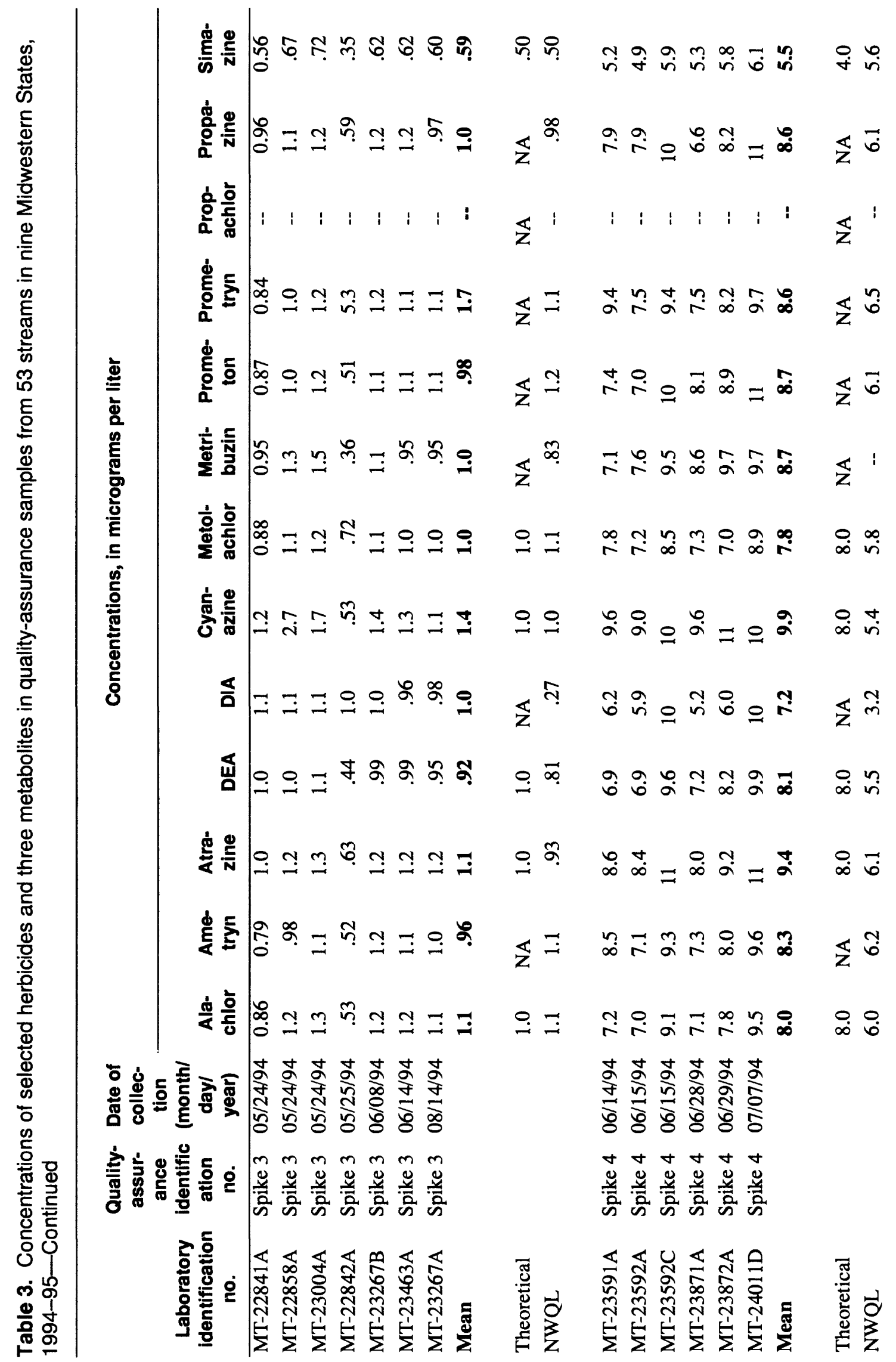




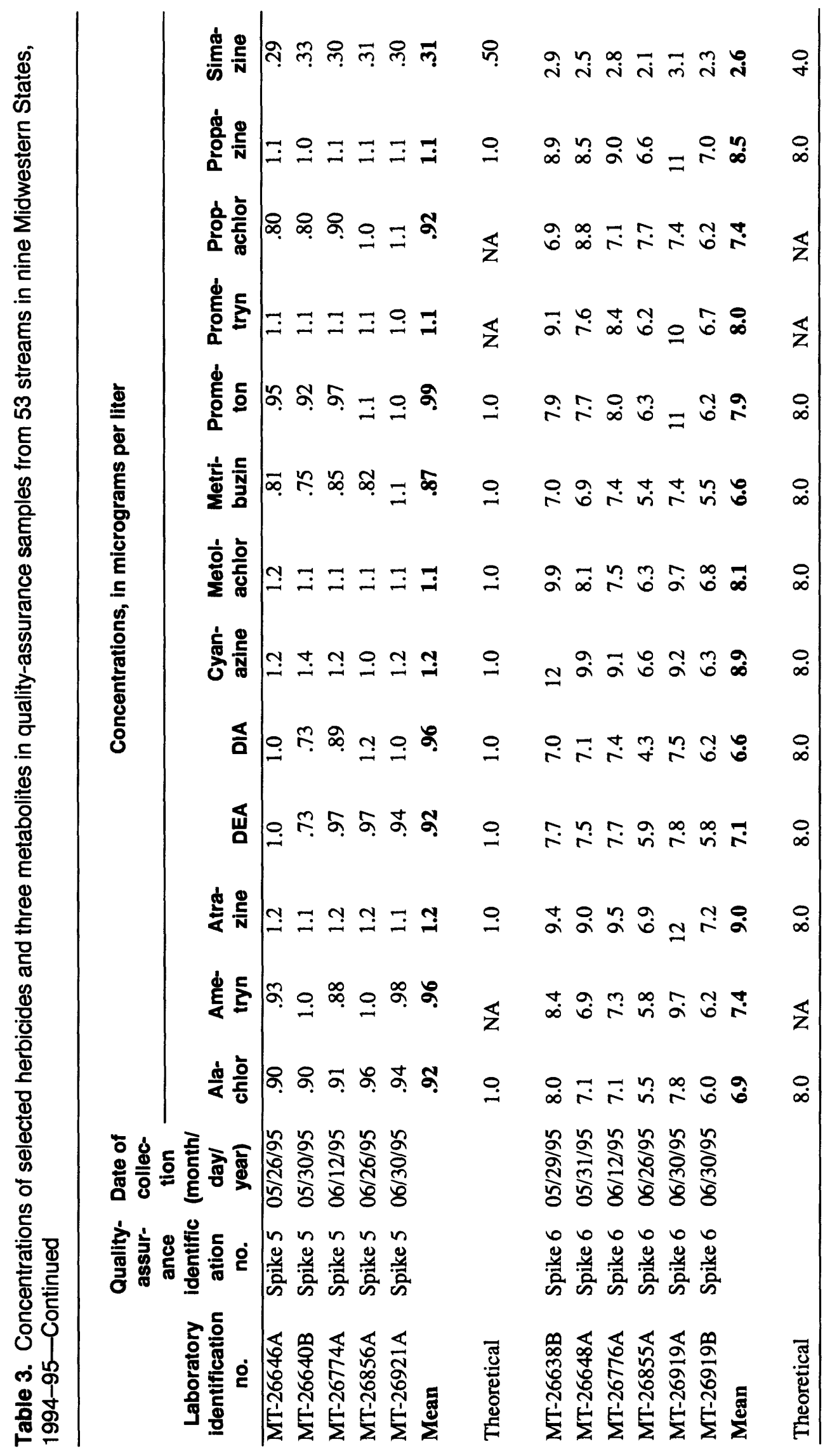


Table 4. Statistical summary of 1994 post-application herbicide and metabolite concentrations in water samples from 53 streams in nine Midwestern States

[MCL, Maximum Contaminant Level; HA, health advisory; $\mu \mathrm{g} / \mathrm{L}$, micrograms per liter; --, not determined; <, less than; propachlor not detected]

\begin{tabular}{|c|c|c|c|c|c|c|c|c|c|}
\hline \multirow[b]{2}{*}{$\begin{array}{l}\text { Herbicide or } \\
\text { metabolite }\end{array}$} & \multirow[b]{2}{*}{$\begin{array}{c}\text { Report- } \\
\text { ing limit } \\
(\mu g / L)\end{array}$} & \multirow[b]{2}{*}{$\begin{array}{c}\text { Number } \\
\text { of } \\
\text { samples }\end{array}$} & \multirow[b]{2}{*}{$\begin{array}{l}\text { Percent } \\
\text { detec- } \\
\text { tions }\end{array}$} & \multicolumn{5}{|c|}{ Concentrations, in micrograms per liter } & \multirow{2}{*}{$\begin{array}{l}\text { Percent- } \\
\text { age }{ }^{1} \\
\text { greater } \\
\text { than four } \\
\text { times } \\
\text { MCL or } \\
\text { HA }\end{array}$} \\
\hline & & & & $\begin{array}{l}\text { 25th per- } \\
\text { centile }\end{array}$ & Median & $\begin{array}{l}\text { 75th per- } \\
\text { centile }\end{array}$ & $\begin{array}{l}\text { Maxi- } \\
\text { mum }\end{array}$ & $\begin{array}{c}\text { MCL or } \\
\text { HA }\end{array}$ & \\
\hline Acetochlor & 0.05 & 53 & 35 & $<0.05$ & $<0.05$ & 0.16 & 1.2 & 2 & 0 \\
\hline Alachlor & .05 & 53 & 78 & .09 & .84 & 2.9 & 10 & 2 & 4 \\
\hline $\begin{array}{l}\text { Alachlor ethane } \\
\text { sulfonic acid }\end{array}$ & .10 & 52 & 100 & 1.1 & 5.2 & 8 & 28 & -- & -- \\
\hline Ametryn & .05 & 53 & 2 & $<.05$ & $<.05$ & $<.05$ & .08 & -- & -- \\
\hline Atrazine & .05 & 53 & 100 & 1.3 & 4.2 & 10 & 28 & 3 & 20 \\
\hline Cyanazine & .05 & 53 & 96 & .36 & 1.2 & 3.2 & 56 & 1 & 20 \\
\hline Cyanazine amide & .05 & 53 & 90 & .16 & .62 & 1.5 & 6.4 & - & - \\
\hline Deethylatrazine & .05 & 53 & 96 & .26 & .71 & 1.4 & 3.5 & -- & -- \\
\hline $\begin{array}{l}\text { Deisopropylatra- } \\
\text { zine }\end{array}$ & .05 & 53 & 92 & .15 & .43 & .73 & 1.8 & -- & -- \\
\hline Metolachlor & .05 & 53 & 94 & .34 & 1.8 & 4 & 11 & 70 & 0 \\
\hline Metribuzin & .05 & 53 & 47 & $<.05$ & $<.05$ & .24 & 1.9 & 200 & 0 \\
\hline Prometon & .05 & 53 & 6 & $<.05$ & $<.05$ & $<.05$ & .22 & -- & -- \\
\hline Prometryn & .05 & 53 & 2 & $<.05$ & $<.05$ & $<.05$ & .06 & -- & -- \\
\hline Propazine & .05 & 53 & 31 & $<.05$ & $<.05$ & .06 & .49 & 10 & 0 \\
\hline Simazine & .05 & 53 & 51 & $<.05$ & .06 & .30 & 4.8 & 4 & 0 \\
\hline Terbutryn & .05 & 53 & 0 & -- & -- & -- & -- & -- & -- \\
\hline
\end{tabular}

${ }^{1}$ Concentrations of individual samples exceeding MCLs do not necessarily represent violation of the Safe Drinking Water Act.

1992). In 1995,28 percent of the cyanazine samples exceeded four times the HA. The remaining herbicide compounds measured in 1995 were similar to those measured in 1994 as shown in tables 4 and 5.

The distribution of the concentrations of all herbicide compounds detected during post-application periods in 1994 and 1995 is shown in figure 3. The compounds are arranged in order of decreasing median concentration.

Box plots showing the distribution of the concentrations of acetochlor, alachlor, atrazine, and cyanazine in water from the 53 sampling sites in 1994 and 1995 are shown in figures 4 and 5 . For comparison, box plots of post-application results from 1989 and 1990 are also shown. The range of concentrations was sim- ilar for all compounds since 1989 , but the medians showed a downward trend except for acetochlor. The decrease in alachlor from 1994 to 1995 is substantial and corresponds with increased use of acetochlor.

Analytical results for 12 herbicides, one alachlor metabolite, two atrazine metabolites, and three cyanazine metabolites in water-quality samples collected from 53 streams during 1994-95 are presented in table 6 at the end of this report. One additional herbicide, terbutryn, was analyzed but not detected.

Analytical results for dissolved nutrients in water samples from the 53 stream sites are given in table 7 at the end of this report. Nitrogen and phosphorus compounds in streams are derived from many humanrelated and natural sources, including chemical fertiliz- 
Table 5. Statistical summary of 1995 post-application herbicide and metabolite concentrations in water samples from 51 streams in nine Midwestern States

[MCL, Maximum Contaminant Level; HA, health advisory; $\mu \mathrm{g} / \mathrm{L}$, micrograms per liter; --, not determined; <, less than]

\begin{tabular}{|c|c|c|c|c|c|c|c|c|c|}
\hline \multirow[b]{2}{*}{ Herbicide or metabolite } & \multirow[b]{2}{*}{$\begin{array}{c}\text { Report- } \\
\text { ing } \\
\text { limit } \\
(\mu g / L)\end{array}$} & \multirow[b]{2}{*}{$\begin{array}{l}\text { Num- } \\
\text { ber of } \\
\text { sam- } \\
\text { ples }\end{array}$} & \multirow[b]{2}{*}{$\begin{array}{l}\text { Per- } \\
\text { cent } \\
\text { detec- } \\
\text { tions }\end{array}$} & \multicolumn{5}{|c|}{ Concentrations, in micrograms per liter } & \multirow{2}{*}{$\begin{array}{c}\text { Per- } \\
\text { cent- } \\
\text { age }{ }^{1} \\
\text { greater } \\
\text { than } \\
\text { four } \\
\text { times } \\
\text { MCL } \\
\text { or HA }\end{array}$} \\
\hline & & & & $\begin{array}{c}\text { 25th } \\
\text { per- } \\
\text { centile }\end{array}$ & Median & $\begin{array}{c}\text { 75th } \\
\text { per- } \\
\text { centile }\end{array}$ & $\begin{array}{l}\text { Maxi- } \\
\text { mum }\end{array}$ & $\begin{array}{c}\text { MCL } \\
\text { or HA }\end{array}$ & \\
\hline Acetochlor & 0.05 & 51 & 82 & 0.08 & 0.42 & 1.2 & 5.6 & 2 & 0 \\
\hline Alachlor & .05 & 51 & 82 & .06 & .13 & .65 & 20 & 2 & 2 \\
\hline Alachlor ethane sulfonic acid & .10 & 51 & 100 & .92 & 1.6 & 4.1 & 23 & -- & -- \\
\hline Ametryn & .05 & 51 & 2 & $<.05$ & $<.05$ & $<.05$ & .08 & - & -- \\
\hline Atrazine & .05 & 51 & 100 & 1.4 & 5.5 & 13 & 50 & 3 & 32 \\
\hline Cyanazine & .05 & 51 & 90 & .38 & 1.3 & 5.2 & 25 & 1 & 28 \\
\hline Cyanazine amide & .05 & 50 & 90 & .12 & .47 & 1.3 & 5.1 & -- & -- \\
\hline Deethylatrazine & .05 & 51 & 96 & .17 & .43 & 1.1 & 6 & -- & -- \\
\hline Deisopropylatrazine & .05 & 51 & 96 & .17 & .42 & .75 & 3.9 & -- & -- \\
\hline Metolachlor & .05 & 51 & 100 & .52 & 1.7 & 6.4 & 18 & 70 & $\mathbf{0}$ \\
\hline Metribuzin & .05 & 51 & 42 & $<.05$ & $<.05$ & .18 & 1.4 & 200 & 0 \\
\hline Prometon & .05 & 51 & 38 & $<.05$ & $<.05$ & .06 & .21 & -- & -- \\
\hline Prometryn & .05 & 51 & 2 & $<.05$ & $<.05$ & $<.05$ & .06 & -- & -- \\
\hline Propachlor & .05 & 51 & 12 & $<.05$ & $<.05$ & $<.05$ & 7.9 & 90 & 0 \\
\hline Propazine & .05 & 51 & 58 & $<.05$ & .05 & .14 & .47 & 10 & 0 \\
\hline Simazine & .05 & 51 & 68 & $<.05$ & .08 & .23 & 7.2 & 4 & 0 \\
\hline Terbutryn & .05 & 51 & 0 & -- & -- & -- & -- & -- & -. \\
\hline
\end{tabular}

${ }^{1}$ Concentrations of individual sample exceeding MCLs do not necessarily represent violation of the Safe Drinking Water Act.

ers, animal wastes, domestic sewages, legumes, mineralization of vegetation, and soil organic matter.

Streamflow and flow percentile are also presented in table 7. The flow percentile was derived from a flow-duration table for each site and represents the percentage of time the streamflow was less than the measured value. For example, a flow percentile of 90 means that 90 percent of the time the streamflow was less than the measured value. Table 7 also includes data on the specific conductance and $\mathrm{pH}$ of all samples.

\section{REFERENCES CITED}

Aga, D.S., Thurman, E.M., and Pomes, M.L., 1994, Determination of alachlor and its ethane-sulfonic acid metabolite in water by solid-phase extraction and enzyme-linked immunosorbent assay: Analytical Chemistry, v. 66, no. 9, p. 1495-1499.

Baker, D.B., and Richards, R.P., 1989, Herbicide concentration patterns in rivers draining intensively cultivated farmlands of northwestern Ohio, in Weigmann, D., ed., Pesticides in the terrestrial and aquatic environments, Proceedings of a National Research Conference, May 11-12, 1989: Blacksburg, Virginia, Virginia Polytechnic Institute \& State University, p. 103-120.

Battaglin, W.A., Goolsby, D.A., and Coupe, R.H., 1993, Annual use and transport of agricultural chemicals in the Mississippi River, 1991-92, in Goolsby, D.A., and others, eds., Selected papers on agricultural chemicals in water resources of the Midcontinental United States: U.S. Geological Survey Open-File Report 93-418, p. 26-38.

Brady, J.F., 1995, Interpretation of immunoassay data, in Nelson, J.O., Karu, A.E., and Wong, R.B., eds., Immu- 


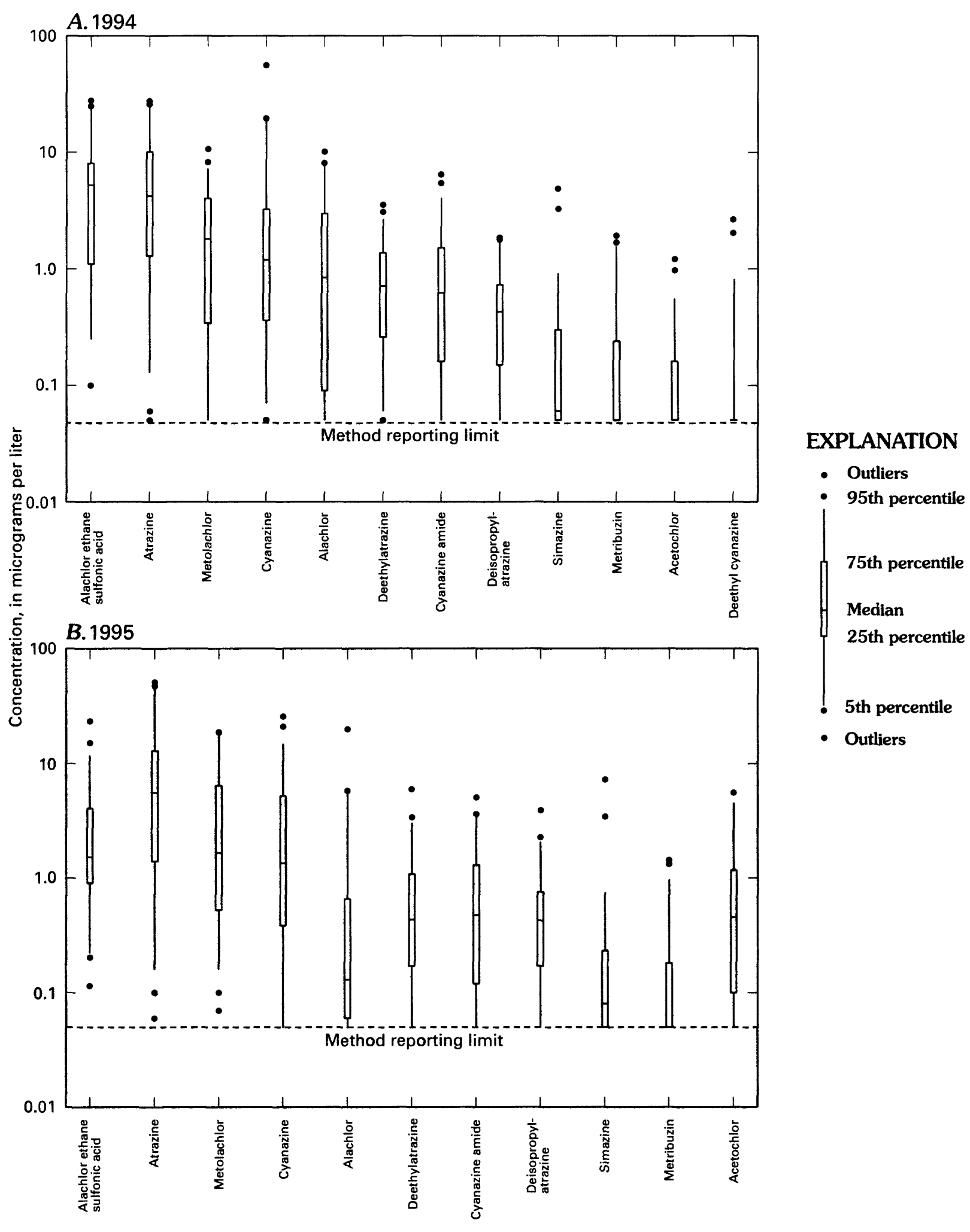

Figure 3. Distribution of concentrations of detected herbicides and metabolites in water from (A) 53 stream sites sampled during 1994 and (B) 51 stream sites sampled during 1995 post-application sampling periods (see tables 4 and 5). 


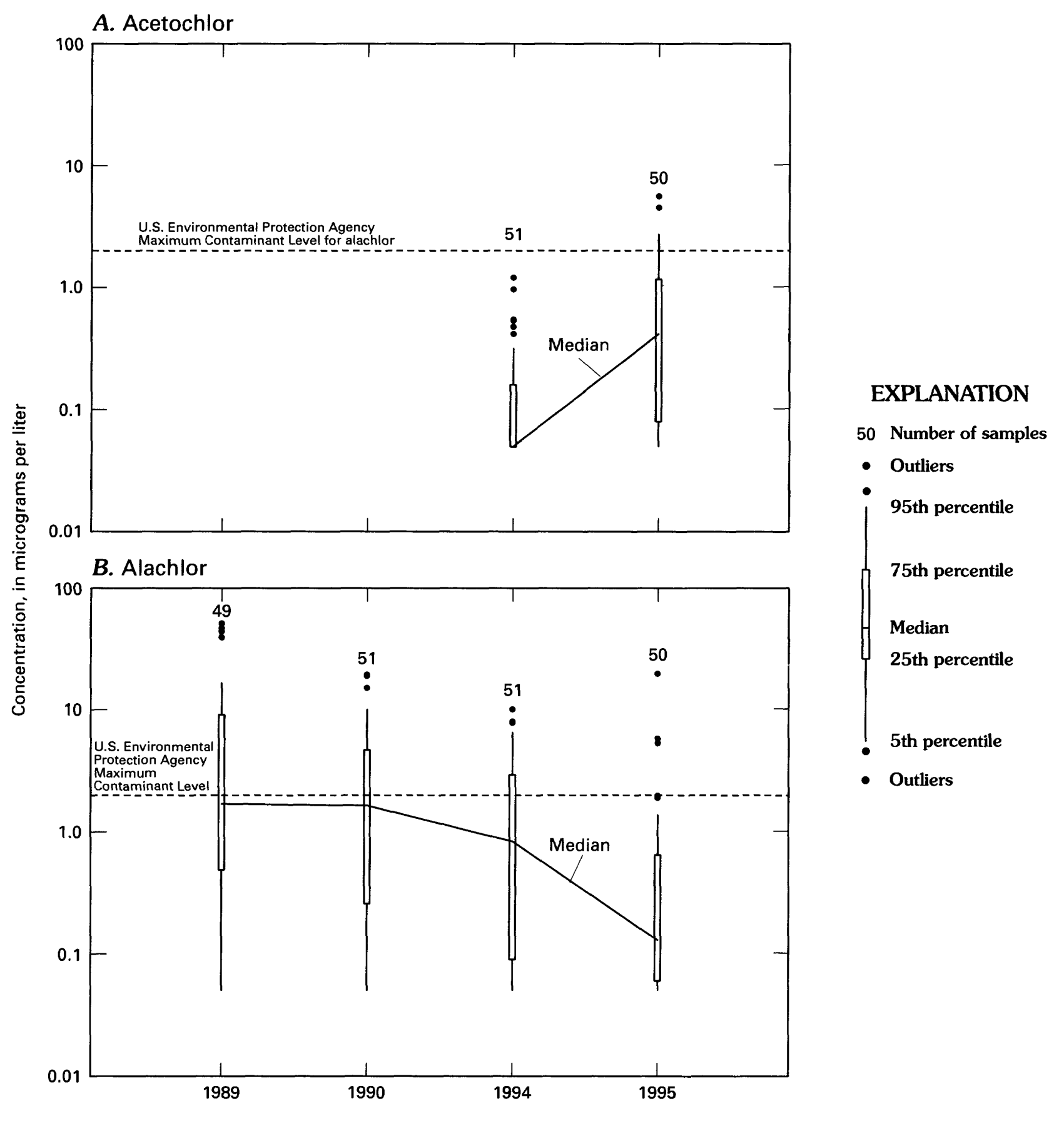

Figure 4. Post-application distributions of $(A)$ acetochlor and $(B)$ alachlor in samples from 53 Midwestern streams, $1989-90$ and 1994-95.

noanalysis of agrochemicals: York, Pennsylvania, Maple Press, chap. 19, p. 266-287.

Fishman, M.J., and Friedman, L.C., 1989, Methods for determination of inorganic substances in water and fluvial sediments: U.S. Geological Survey Techniques of Water-Resources Investigations, book 5, chap. A1, $545 \mathrm{p}$.
Frank, Richard, Braun, H.E., Holdrinet, M. Van Hove, Sirons, G.J., and Ripley, B.D., 1982, Agriculture and water quality in the Canadian Great Lakes Basin V., Pesticide use in 11 agricultural watersheds and presence in streamwater, 1975-1977: Journal of Environmental Quality, v. 11, p. 497-505.

Gianessi, L.P., 1992, U.S. pesticide use trends-1966-1989: Resources for the Future, $22 \mathrm{p}$. 
A. Atrazine

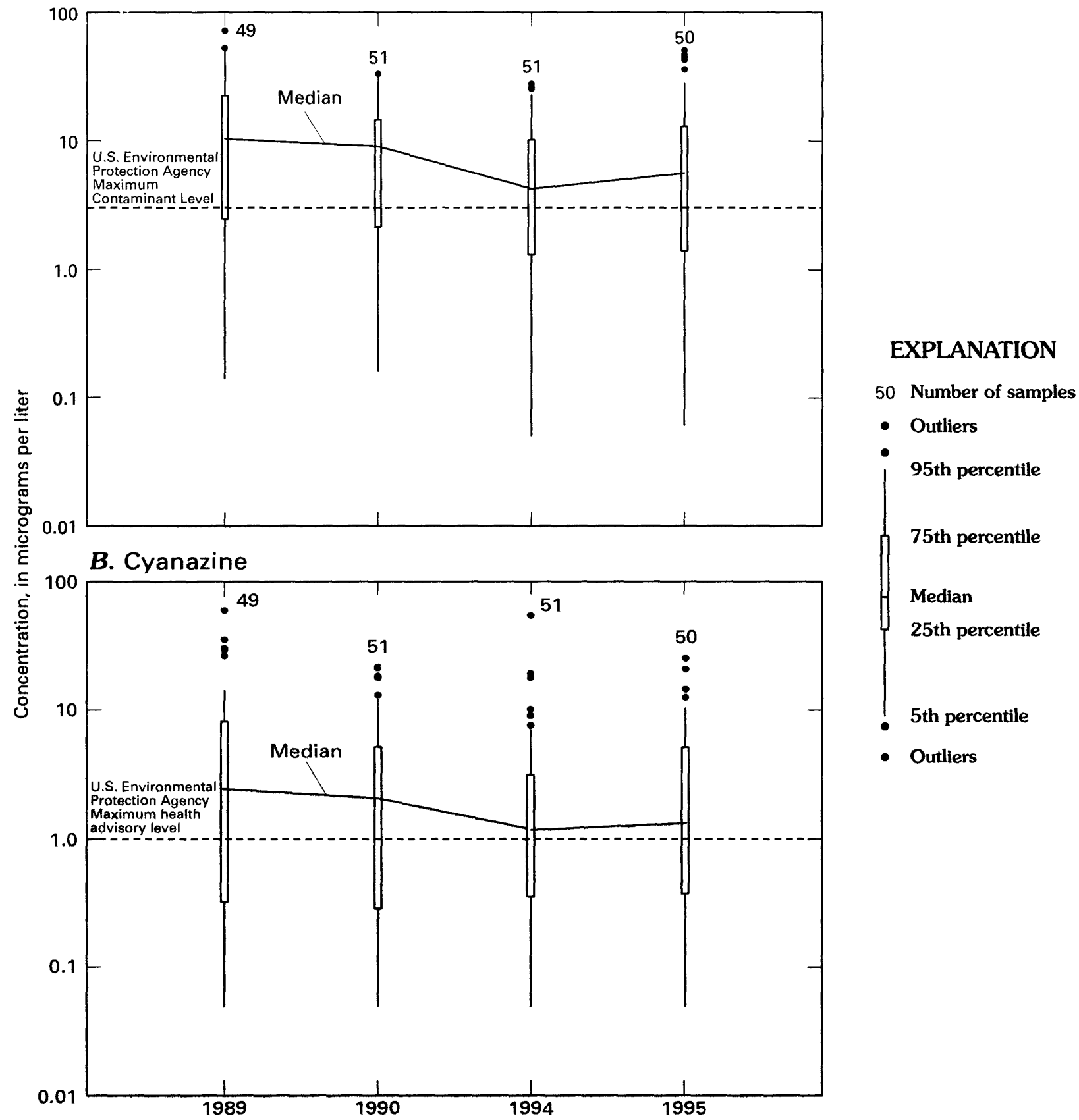

Figure 5. Post-application distributions of $(A)$ atrazine and $(B)$ cyanazine in samples from 53 Midwestern streams, 1989-90 and 1994-95.

Goolsby, D.A., and Battaglin, W.A., 1993, Occurrence, distribution, and transport of agricultural chemicals in surface waters of the Midwestern United States, in Goolsby, D.A., and others, eds., Selected papers on agricultural chemicals in water resources of the Midcontinental United States: U.S. Geological Survey Open-File Report 93-418, p. 1-24.
Goolsby, D.A., Battaglin, W.A., and Thurman, E.M., 1993, Occurrence and transport of agricultural chemicals in the Mississippi River Basin, July through August 1993: U.S. Geological Survey Circular 1120-C, 22 p.

Goolsby, D.A., Boyer, L.L., and Battaglin, W.A., 1994, Plan of study to determine the effect of changes in herbicide use on herbicide concentrations in Midwestern streams, 1989-94: U.S. Geological Survey Open-File Report 94-347, 14 p. 
Goolsby, D.A., Scribner, E.A., Thurman, E.M., Meyer, M.T., and Pomes, M.L., 1995, Data on selected herbicides and two triazine metabolites in precipitation of the Midwestern and Northeastern United States, 1990-91: U.S. Geological Survey Open-File Report 95-469, $341 \mathrm{p}$.

Goolsby, D.A., Thurman, E.M., and Kolpin, D.W., 1991, Geographic and temporal distribution of herbicides in surface waters of the upper Midwestern United States, 1989-90, in Mallard, G.E., and Aronson, D.A., eds., U.S. Geological Survey Toxic Substances Hydrology Program-Proceedings of the technical meeting, Monterey, California, March 11-15, 1991: U.S. Geological Survey Water-Resources Investigations Report 91-4034, p. 183-188.

Kolpin, D.W., Burkart, M.R., and Thurman, E.M., 1993, Hydrogeologic, water-quality, and land-use data for the reconnaissance of herbicides and nitrate in near-surface aquifers of the Midcontinental United States: U.S. Geological Survey Open-File Report 93-114, 61 p.

Leonard, R.A., 1988, Herbicides in surface waters, in Grover, R., ed., Environmental chemistry of herbicides, v. I: Boca Raton, Florida, CRC Press, p. 45-87.

Lin, Biing-Hwan, Padgitt, Merritt, Bull, Len, Delvo, Herman, Shank, David, and Taylor, Harold, 1995, Pesticide and fertilizer use and trends in U.S. agriculture: Washington, D.C., U.S. Department of Agriculture, Agriculture Economic Report Number 717, 47 p.

Meyer, M.T., 1994, Geochemistry of cyanazine and its metabolites-Indicators of contaminant transport in surface water of the Midwestern United States: Lawrence, University of Kansas, Department of Geology, Ph.D. dissertation, 364 p.

Meyer, M.T., Mills, M.S., and Thurman, E.M., 1993, Automated solid-phase extraction of herbicides from water for gas chromatography/mass spectrometry analysis: Journal of Chromatography, v. 629, p. 55-59.

Scribner, E.A., Goolsby, D.A., Thurman, E.M., Meyer, M.T., and Battaglin, W.A., 1996, Concentrations of selected herbicides, herbicide metabolites, and nutrients in outflow from selected Midwestern reservoirs, April 1992 through September 1993: U.S. Geological Survey Open-File Report 96-393, 128 p.

Scribner, E.A., Goolsby, D.A., Thurman, E.M., Meyer, M.T., and Pomes, M.L., 1994, Concentrations of selected herbicides, two triazine metabolites, and nutrients in storm runoff from nine stream basins in the Midwestern United States, 1990-92: U.S. Geological Survey Open-File Report 94-396, 144 p.

Scribner, E.A., Thurman, E.M., Goolsby, D.A., Meyer, M.T., Mills, M.S., and Pomes, M.L., 1993, Reconnaissance data for selected herbicides, two atrazine metabolites, and nitrate in surface water of the Midwestern United States, 1989-90: U.S. Geological Survey Open-File Report 93-457, 77 p.
Snow, D.D., and Spalding, R.F., 1988, Soluble pesticide levels in the Platte River basin of Nebraska, in Agricultural impacts on ground water-A conference, Des Moines, Iowa, March 21-23, 1988, Proceedings: American Association of Ground Water Scientists and Engineers, p. 211-233.

Thurman, E.M., Goolsby, D.A., Meyer, M.T., and Kolpin, D.W., 1991, Herbicides in surface waters of the Midwestern United States-The effect of spring flush: Environmental Science \& Technology, v. 25, p. 1794-1796.

Thurman, E.M., Goolsby, D.A., Meyer, M.T., Mills, M.S., Pomes, M.L., and Kolpin, D.W., 1992, A reconnaissance study of herbicides and their metabolites in surface water of the Midwestern United States using immunoassay and gas chromatography/mass spectrometry: Environmental Science \& Technology, v. 26, no. 12 , p. $2440-2447$.

Thurman, E.M., Meyer, M.T., Pomes, M.L., Perry, C.E., and Schwab, A.P., 1990, Enzyme-linked immunosorbent assay compared with gas chromatography/mass spectrometry for the determination of herbicides in water: Analytical Chemistry, v. 62, p. 2043-2048.

U.S. Department of Agriculture, 1991, Agricultural chemical usage-1990 field crops summary: Washington, D.C., U.S. Department of Agriculture, National Agricultural Statistics Service, 154 p.

-1992, Agricultural chemical usage-1991 field crops summary: Washington, D.C., U.S. Department of Agriculture, National Agricultural Statistics Service, 118 p. 1993, Agricultural chemical usage_-1992 field crops summary: Washington, D.C., U.S. Department of Agriculture, National Agricultural Statistics Service, $114 \mathrm{p}$. 1994, Agricultural chemical usage-1993 field crops summary: Washington, D.C., U.S. Department of Agriculture, National Agricultural Statistics Service, 114 p. 1995, Agricultural chemical usage - 1994 field crops summary: Washington, D.C., U.S. Department of Agriculture, National Agricultural Statistics Service, 106 p.

U.S. Environmental Protection Agency, 1992, Drinking water regulations and health advisories: Washington, D.C., U.S. Environmental Protection Agency, 11 p.

Ward, J.R., and Harr, C.A., 1990, Methods for collection and processing of surface-water and bed-material samples for physical and chemical analyses: U.S. Geological Survey Open-File Report 90-140, 71 p.

Wauchope, R.D., 1978, The pesticide content of surface water draining from agricultural fields-A review: Journal of Environmental Quality, v. 7, p. 459-472. 
Table 6. Analytical results for selected herbicides and six metabolites in water $[--$, no data; <, less than. Sample type: R, regular; T, temporal distribution; TD, temporad distribution duplicate

\begin{tabular}{|c|c|c|c|c|c|c|c|c|c|c|}
\hline \multirow[b]{2}{*}{$\begin{array}{c}\text { Map } \\
\text { no. } \\
\text { (fig. 1) }\end{array}$} & \multirow[b]{2}{*}{ Site name } & \multirow[b]{2}{*}{$\begin{array}{l}\text { Date of } \\
\text { collec- } \\
\text { tion } \\
\text { (month/ } \\
\text { dayl } \\
\text { year) }\end{array}$} & \multirow[b]{2}{*}{$\begin{array}{l}\text { Sam- } \\
\text { ple } \\
\text { type }\end{array}$} & \multirow[b]{2}{*}{$\begin{array}{l}\text { Aceto- } \\
\text { chlor }\end{array}$} & \multicolumn{6}{|c|}{ Concentration, in micrograms per liter } \\
\hline & & & & & $\begin{array}{l}\text { Ala- } \\
\text { chlor }\end{array}$ & $\begin{array}{l}\text { Ala- } \\
\text { chlor } \\
\text { ethane } \\
\text { sul- } \\
\text { fonic } \\
\text { acid }\end{array}$ & $\begin{array}{l}\text { Ame- } \\
\text { tryn }\end{array}$ & $\begin{array}{l}\text { Atra- } \\
\text { zine }\end{array}$ & $\begin{array}{l}\text { De- } \\
\text { ethyl- } \\
\text { atra- } \\
\text { zine }\end{array}$ & $\begin{array}{c}\text { Deiso- } \\
\text { propyl- } \\
\text { atra- } \\
\text { zine }\end{array}$ \\
\hline & & & & & & & & & & Iowa \\
\hline \multirow[t]{4}{*}{1} & Turkey River at Spillville & $03 / 22 / 94$ & $\mathbf{R}$ & $<0.05$ & 0.08 & 5.2 & $<0.05$ & 0.39 & 0.48 & 0.22 \\
\hline & & $05 / 24 / 94$ & $\mathbf{R}$ & $<.05$ & .14 & 3.9 & $<.05$ & .31 & .31 & .06 \\
\hline & & $06 / 08 / 95$ & $\mathbf{R}$ & .62 & 1.9 & 11 & $<.05$ & 17 & 1.1 & .75 \\
\hline & & & & $<.05$ & & & & & & \\
\hline \multirow[t]{4}{*}{2} & Wapsipinicon River at & $03 / 22 / 94$ & $\mathbf{R}$ & $<.05$ & .09 & 5.0 & $<.05$ & .34 & .37 & .11 \\
\hline & Independence & $05 / 24 / 94$ & $\mathbf{R}$ & $<.05$ & .08 & 5.4 & $<.05$ & .37 & .26 & .08 \\
\hline & & $05 / 30 / 95$ & B & .34 & .09 & 4.2 & $<.05$ & .66 & .37 & .21 \\
\hline & & $05 / 30 / 95$ & $\mathbf{R}$ & .36 & .10 & 3.3 & $<.05$ & .67 & .29 & .14 \\
\hline \multirow[t]{13}{*}{3} & Old Mans Creek near Iowa & $03 / 21 / 94$ & $\mathbf{R}$ & $<.05$ & $<.05$ & 1.2 & $<.05$ & .14 & .11 & .11 \\
\hline & City & $05 / 24 / 94$ & $\mathbf{R}$ & $<.05$ & $<.05$ & 1.1 & $<.05$ & .39 & .13 & .25 \\
\hline & & $06 / 02 / 95$ & $\mathbf{R}$ & 1.5 & .54 & 7.1 & $<.05$ & 13 & .14 & 1.3 \\
\hline & & $06 / 14 / 95$ & $\mathbf{T}$ & .10 & .07 & 2.2 & .15 & .77 & .32 & .27 \\
\hline & & $07 / 05 / 95$ & TD & .12 & .05 & 1.0 & $<.05$ & 3.4 & 1.1 & .72 \\
\hline & & $07 / 05 / 95$ & $\mathbf{T}$ & .10 & $<.05$ & 1.4 & $<.05$ & 1.9 & .55 & .44 \\
\hline & & $07 / 06 / 95$ & $\mathbf{T}$ & .17 & .55 & 2.1 & $<.05$ & 3.0 & .74 & .53 \\
\hline & & $07 / 19 / 95$ & $\mathbf{T}$ & $<.05$ & $<.05$ & 4.4 & $<.05$ & .38 & .24 & .19 \\
\hline & & $08 / 09 / 95$ & $\mathbf{T}$ & $<.05$ & $<.05$ & 3.1 & $<.05$ & .24 & .14 & .12 \\
\hline & & $08 / 09 / 95$ & $\mathbf{T}$ & $<.05$ & $<.05$ & 3.1 & $<.05$ & .26 & .15 & .15 \\
\hline & & $08 / 09 / 95$ & TD & $<.05$ & $<.05$ & 2.8 & $<.05$ & .25 & .14 & .14 \\
\hline & & $08 / 09 / 95$ & $\mathbf{T}$ & $<.05$ & $<.05$ & 4.1 & $<.05$ & .27 & .15 & .14 \\
\hline & & $08 / 14 / 95$ & $\mathbf{T}$ & $<.05$ & $<.05$ & 3.0 & $<.05$ & .21 & .12 & .10 \\
\hline \multirow[t]{6}{*}{4} & North Skunk River near & $03 / 24 / 94$ & $\mathbf{R}$ & $<.05$ & $<.05$ & 1.5 & $<.05$ & .14 & .11 & .09 \\
\hline & Sigourney & $05 / 25 / 94$ & $\mathbf{R}$ & $<.05$ & $<.05$ & 1.5 & $<.05$ & .61 & .12 & .11 \\
\hline & & $06 / 06 / 95$ & $\mathbf{R}$ & 2.7 & $<.05$ & 1.3 & $<.05$ & 17 & .91 & 1.1 \\
\hline & & $06 / 06 / 95$ & L & 3.1 & .05 & 1.2 & $<.05$ & 19 & 1.0 & 1.1 \\
\hline & & $03 / 24 / 94$ & B & $<.05$ & $<.05$ & 1.7 & $<.05$ & .17 & .10 & .09 \\
\hline & & $03 / 24 / 94$ & B & $<.05$ & $<.05$ & 2.1 & $<.05$ & .21 & .13 & .16 \\
\hline
\end{tabular}


samples from 53 streams in nine Midwestern States, 1994-95

B, blind duplicate; L, laboratory duplicate; X, extra; XD, extra duplicate. Terbutryn was not detected]

Concentration, in micrograms per liter

\begin{tabular}{|c|c|c|c|c|c|c|c|c|c|c|c|}
\hline $\begin{array}{c}\text { Map } \\
\text { no. } \\
\text { (fig. 1) }\end{array}$ & $\begin{array}{l}\text { Cyana- } \\
\text { zine }\end{array}$ & $\begin{array}{l}\text { Cyana- } \\
\text { zine } \\
\text { amide }\end{array}$ & $\begin{array}{l}\text { De- } \\
\text { ethyl- } \\
\text { cyana- } \\
\text { zine }\end{array}$ & $\begin{array}{l}\text { De- } \\
\text { ethyl- } \\
\text { cyana- } \\
\text { zine }\end{array}$ & $\begin{array}{l}\text { Meto- } \\
\text { lachlor }\end{array}$ & $\begin{array}{l}\text { Metri- } \\
\text { buzin }\end{array}$ & $\begin{array}{c}\text { Prome- } \\
\text { ton }\end{array}$ & $\begin{array}{l}\text { Prome- } \\
\text { tryn }\end{array}$ & $\begin{array}{l}\text { Propa- } \\
\text { chlor }\end{array}$ & $\begin{array}{l}\text { Propa- } \\
\text { zine }\end{array}$ & $\begin{array}{c}\text { Sima- } \\
\text { zine }\end{array}$ \\
\hline \multirow[t]{3}{*}{1} & $<0.05$ & 0.11 & $<0.05$ & $<0.50$ & 0.11 & $<0.05$ & $<0.05$ & $<0.05$ & -- & $<0.05$ & $<0.05$ \\
\hline & .07 & .05 & $<.05$ & $<.50$ & .05 & $<.05$ & $<.05$ & $<.05$ & -- & $<.05$ & $<.05$ \\
\hline & 10 & 3.0 & -- & -- & .38 & $<.05$ & $<.05$ & $<.05$ & $<0.05$ & .14 & .05 \\
\hline \multirow[t]{4}{*}{2} & $<.05$ & .08 & $<.05$ & $<.50$ & .15 & $<.05$ & $<.05$ & $<.05$ & -- & $<.05$ & $<.05$ \\
\hline & .09 & .05 & $<.05$ & $<.50$ & .11 & $<.05$ & $<.05$ & $<.05$ & -. & $<.05$ & $<.05$ \\
\hline & .57 & .10 & -- & -- & .48 & $<.05$ & $<.05$ & $<.05$ & $<.05$ & $<.05$ & $<.05$ \\
\hline & .54 & .09 & - & -- & .50 & $<.05$ & $<.05$ & $<.05$ & $<.05$ & $<.05$ & $<.05$ \\
\hline \multirow[t]{13}{*}{3} & $<.05$ & .11 & $<.05$ & $<.50$ & $<.05$ & $<.05$ & $<.05$ & $<.05$ & -- & $<.05$ & $<.05$ \\
\hline & .25 & .16 & $<.05$ & $<.50$ & .07 & $<.05$ & $<.05$ & $<.05$ & -- & $<.05$ & $<.05$ \\
\hline & 21 & 5.1 & -- & -- & 2.9 & .05 & $<.05$ & $<.05$ & $<.05$ & .14 & .07 \\
\hline & .42 & .19 & -- & -- & .17 & $<.05$ & .11 & .15 & .06 & .06 & $<.05$ \\
\hline & 2.7 & $<.05$ & -- & -- & 1.2 & .05 & $<.05$ & $<.05$ & $<.05$ & $<.05$ & $<.05$ \\
\hline & 1.3 & $<.05$ & -- & -- & .41 & $<.05$ & $<.05$ & $<.05$ & $<.05$ & $<.05$ & $<.05$ \\
\hline & 1.1 & $<.05$ & -- & -- & .45 & $<.05$ & $<.05$ & $<.05$ & $<.05$ & $<.05$ & $<.05$ \\
\hline & .18 & .20 & -- & -- & .05 & $<.05$ & $<.05$ & $<.05$ & $<.05$ & $<.05$ & $<.05$ \\
\hline & .05 & .09 & -- & -- & .05 & $<.05$ & $<.05$ & $<.05$ & $<.05$ & $<.05$ & $<.05$ \\
\hline & .05 & .09 & -- & -- & .05 & $<.05$ & $<.05$ & $<.05$ & $<.05$ & $<.05$ & $<.05$ \\
\hline & $<.05$ & .08 & -- & -- & .05 & $<.05$ & $<.05$ & $<.05$ & $<.05$ & $<.05$ & $<.05$ \\
\hline & $<.05$ & .09 & -- & -- & .06 & $<.05$ & $<.05$ & $<.05$ & $<.05$ & $<.05$ & $<.05$ \\
\hline & $<.05$ & .07 & -- & -- & $<.05$ & $<.05$ & $<.05$ & $<.05$ & $<.05$ & $<.05$ & $<.05$ \\
\hline \multirow[t]{6}{*}{4} & $<.05$ & .09 & $<.05$ & $<.50$ & $<.05$ & $<.05$ & $<.05$ & $<.05$ & -- & $<.05$ & $<.05$ \\
\hline & .29 & .10 & $<.05$ & $<.50$ & .12 & $<.05$ & $<.05$ & $<.05$ & -- & $<.05$ & $<.05$ \\
\hline & 26 & 2.7 & -- & -- & 3.0 & .07 & $<.05$ & $<.05$ & $<.05$ & .16 & .08 \\
\hline & 31 & 3.2 & -- & -- & 3.5 & .08 & $<.05$ & $<.05$ & $<.05$ & .18 & .09 \\
\hline & $<.05$ & $<.05$ & $<.05$ & $<.50$ & .06 & $<.05$ & $<.05$ & $<.05$ & -- & $<.05$ & $<.05$ \\
\hline & .06 & $<.05$ & $<.05$ & $<.50$ & .09 & $<.05$ & $<.05$ & $<.05$ & -- & $<.05$ & $<.05$ \\
\hline
\end{tabular}


Table 6. Analytical results for selected herbicides and six metabolites in water

\begin{tabular}{|c|c|c|c|c|c|c|c|c|c|c|}
\hline \multirow[b]{2}{*}{$\begin{array}{c}\text { Map } \\
\text { no. } \\
\text { (fig. 1) }\end{array}$} & \multirow[b]{2}{*}{ Site name } & \multirow[b]{2}{*}{$\begin{array}{c}\text { Date of } \\
\text { collec- } \\
\text { tion } \\
\text { (month/ } \\
\text { dayl } \\
\text { year) }\end{array}$} & \multirow[b]{2}{*}{$\begin{array}{c}\text { Sam- } \\
\text { ple } \\
\text { type }\end{array}$} & \multirow[b]{2}{*}{$\begin{array}{l}\text { Aceto- } \\
\text { chlor }\end{array}$} & \multicolumn{6}{|c|}{ Concentration, in micrograms per liter } \\
\hline & & & & & $\begin{array}{l}\text { Ala- } \\
\text { chlor }\end{array}$ & $\begin{array}{c}\text { Ala- } \\
\text { chlor } \\
\text { ethane } \\
\text { sul- } \\
\text { fonic } \\
\text { acid }\end{array}$ & $\begin{array}{l}\text { Ame- } \\
\text { trynn }\end{array}$ & $\begin{array}{l}\text { Atra- } \\
\text { zine }\end{array}$ & $\begin{array}{l}\text { De- } \\
\text { ethyl- } \\
\text { atra- } \\
\text { zine }\end{array}$ & $\begin{array}{c}\text { Deiso- } \\
\text { propyl- } \\
\text { atra- } \\
\text { zine }\end{array}$ \\
\hline & & & & & & & & & Iowa- & Continued \\
\hline \multirow[t]{3}{*}{5} & Skunk River at Augusta & $03 / 24 / 94$ & $\mathbf{R}$ & $<0.05$ & $<0.05$ & 0.89 & $<0.05$ & 0.15 & 0.12 & 0.12 \\
\hline & & $06 / 03 / 94$ & $\mathbf{R}$ & $<.05$ & .09 & 2.3 & $<.05$ & 1.5 & .28 & .18 \\
\hline & & $06 / 08 / 95$ & $\mathbf{R}$ & 1.7 & .06 & 1.1 & $<.05$ & 10 & .64 & .85 \\
\hline \multirow[t]{4}{*}{6} & Des Moines River at Fort & $03 / 23 / 94$ & $\mathbf{R}$ & $<.05$ & .05 & 1.4 & $<.05$ & .17 & .07 & .05 \\
\hline & Dodge & $06 / 06 / 94$ & $\mathbf{R}$ & $<.05$ & .12 & 2.4 & $<.05$ & .92 & .13 & .08 \\
\hline & & $05 / 29 / 95$ & $\mathbf{R}$ & 1.4 & .32 & 1.4 & $<.05$ & .39 & .08 & .07 \\
\hline & & $05 / 29 / 95$ & $\mathbf{L}$ & 1.3 & .30 & -- & $<.05$ & .37 & .08 & .07 \\
\hline \multirow[t]{3}{*}{7} & Raccoon River at Van Meter & $03 / 23 / 94$ & $\mathbf{R}$ & $<.05$ & $<.05$ & .98 & $<.05$ & .12 & .07 & .05 \\
\hline & & $05 / 26 / 94$ & $\mathbf{R}$ & $<.05$ & $<.05$ & .81 & $<.05$ & .33 & .09 & .10 \\
\hline & & $05 / 29 / 95$ & $\mathbf{R}$ & 4.5 & .10 & .72 & $<.05$ & 5.9 & .24 & .31 \\
\hline \multirow[t]{3}{*}{8} & Little Sioux River at & $03 / 24 / 94$ & $\mathbf{R}$ & $<.05$ & $<.05$ & 1.0 & $<.05$ & .22 & .10 & .08 \\
\hline & Correctionville & $06 / 06 / 94$ & $\mathbf{R}$ & $<.05$ & $<.05$ & .99 & $<.05$ & .34 & .10 & .10 \\
\hline & & $05 / 28 / 95$ & $\mathbf{R}$ & .88 & .10 & .79 & $<.05$ & 1.4 & .11 & .15 \\
\hline \multirow[t]{3}{*}{9} & Maple River at Mapleton & $03 / 24 / 94$ & $\mathbf{R}$ & $<.05$ & $<.05$ & .33 & $<.05$ & .13 & .10 & .10 \\
\hline & & $06 / 05 / 94$ & $\mathbf{R}$ & .16 & $<.05$ & .25 & $<.05$ & 1.4 & .14 & .09 \\
\hline & & $05 / 28 / 95$ & $\mathbf{R}$ & 2.7 & .06 & .23 & $<.05$ & 5.2 & .25 & .49 \\
\hline \multirow[t]{5}{*}{10} & Boyer River at Logan & $03 / 24 / 94$ & $\mathbf{R}$ & $<.05$ & $<.05$ & .36 & $<.05$ & .09 & $<.05$ & $<.05$ \\
\hline & & $06 / 02 / 94$ & $\mathbf{X}$ & $<.05$ & .08 & .41 & $<.05$ & 1.8 & .10 & .09 \\
\hline & & $06 / 05 / 94$ & $\mathbf{R}$ & .20 & .34 & .73 & $<.05$ & 4.7 & .54 & .50 \\
\hline & & $05 / 28 / 95$ & $\mathbf{R}$ & .89 & .15 & .34 & $<.05$ & 2.0 & .11 & .19 \\
\hline & & & & & & & & & & minois \\
\hline \multirow[t]{4}{*}{11} & Bonpas Creek at Browns & $03 / 23 / 94$ & $\mathbf{R}$ & $<.05$ & $<.05$ & .82 & $<.05$ & .14 & .05 & $<.05$ \\
\hline & & $06 / 24 / 94$ & $\mathbf{R}$ & $<.05$ & 3.7 & 10 & $<.05$ & 15 & 3.1 & 1.8 \\
\hline & & $06 / 28 / 95$ & $\mathbf{R}$ & 1.2 & 1.9 & 15 & $<.05$ & 50 & 6.0 & 3.9 \\
\hline & & $06 / 29 / 95$ & $\mathbf{X}$ & .77 & 1.5 & 8.7 & .28 & 29 & 5.2 & 3.4 \\
\hline \multirow[t]{5}{*}{12} & Little Wabash River at Carmi & $03 / 23 / 94$ & $\mathbf{R}$ & $<.05$ & $<.05$ & .97 & $<.05$ & .15 & .05 & $<.05$ \\
\hline & & $03 / 23 / 94$ & $\mathbf{L}$ & $<.05$ & $<.05$ & .96 & $<.05$ & .20 & $<.05$ & $<.05$ \\
\hline & & $06 / 28 / 94$ & $\mathbf{R}$ & .11 & 2.9 & 23 & $<.05$ & 11 & 2.6 & 1.8 \\
\hline & & $06 / 29 / 95$ & $\mathbf{R}$ & .80 & 1.1 & 8.8 & $<.05$ & 27 & 3.0 & 2.3 \\
\hline & & $06 / 29 / 95$ & B & .82 & 1.1 & 9.1 & $<.05$ & 28 & 3.0 & 2.3 \\
\hline
\end{tabular}




\section{Concentration, in micrograms per liter}

\begin{tabular}{|c|c|c|c|c|c|c|c|c|c|c|c|}
\hline $\begin{array}{c}\text { Map } \\
\text { no. } \\
\text { (fig. 1) }\end{array}$ & $\begin{array}{l}\text { Cyana- } \\
\text { zine }\end{array}$ & $\begin{array}{l}\text { Cyana- } \\
\text { zine } \\
\text { amide }\end{array}$ & $\begin{array}{l}\text { De- } \\
\text { ethyl- } \\
\text { cyana- } \\
\text { zine }\end{array}$ & $\begin{array}{l}\text { De- } \\
\text { ethyl- } \\
\text { cyana- } \\
\text { zine }\end{array}$ & $\begin{array}{l}\text { Meto- } \\
\text { lachlor }\end{array}$ & $\begin{array}{l}\text { Metri- } \\
\text { buzin }\end{array}$ & $\begin{array}{c}\text { Prome- } \\
\text { ton }\end{array}$ & $\begin{array}{c}\text { Prome- } \\
\text { tryn }\end{array}$ & $\begin{array}{l}\text { Propa- } \\
\text { chlor }\end{array}$ & $\begin{array}{l}\text { Propa- } \\
\text { zine }\end{array}$ & $\begin{array}{c}\text { Sima- } \\
\text { zine }\end{array}$ \\
\hline \multirow[t]{3}{*}{5} & $<0.05$ & 0.09 & $<0.05$ & $<0.50$ & 0.05 & $<0.05$ & $<0.05$ & $<0.05$ & -- & $<0.05$ & $<0.05$ \\
\hline & 1.1 & .67 & $<.05$ & $<.50$ & .40 & $<.05$ & $<.05$ & $<.05$ & -- & $<.05$ & $<.05$ \\
\hline & 15 & 2.3 & -- & -- & 2.4 & .08 & .09 & $<.05$ & $<0.05$ & .10 & .07 \\
\hline \multirow[t]{4}{*}{6} & $<.05$ & .17 & $<.05$ & $<.50$ & .19 & $<.05$ & $<.05$ & $<.05$ & -- & $<.05$ & $<.05$ \\
\hline & .84 & .27 & $<.05$ & $<.50$ & .26 & $<.05$ & $<.05$ & $<.05$ & -- & $<.05$ & .05 \\
\hline & .31 & .09 & -- & -- & 2.6 & $<.05$ & $<.05$ & $<.05$ & .17 & $<.05$ & $<.05$ \\
\hline & .33 & .07 & -- & -- & 2.4 & $<.05$ & $<.05$ & $<.05$ & .17 & $<.05$ & $<.05$ \\
\hline \multirow[t]{3}{*}{7} & $<.05$ & .08 & $<.05$ & $<.50$ & .08 & $<.05$ & $<.05$ & $<.05$ & -- & $<.05$ & $<.05$ \\
\hline & .25 & .06 & $<.05$ & $<.50$ & .37 & $<.05$ & $<.05$ & $<.05$ & -- & $<.05$ & $<.05$ \\
\hline & 7.0 & .58 & -- & -- & 6.7 & $<.05$ & $<.05$ & $<.05$ & $<.05$ & .05 & $<.05$ \\
\hline \multirow[t]{3}{*}{8} & $<.05$ & .13 & $<.05$ & $<.50$ & .09 & $<.05$ & $<.05$ & $<.05$ & -- & $<.05$ & $<.05$ \\
\hline & .09 & .09 & $<.05$ & $<.50$ & .10 & $<.05$ & $<.05$ & $<.05$ & -- & $<.05$ & $<.05$ \\
\hline & 1.6 & .17 & -- & -- & 3.3 & $<.05$ & $<.05$ & $<.05$ & $<.05$ & $<.05$ & $<.05$ \\
\hline \multirow[t]{3}{*}{9} & $<.05$ & .06 & $<.05$ & $<.50$ & .08 & $<.05$ & $<.05$ & $<.05$ & -- & $<.05$ & $<.05$ \\
\hline & .80 & .16 & .05 & $<.50$ & .54 & $<.05$ & $<.05$ & $<.05$ & -- & $<.05$ & $<.05$ \\
\hline & 13 & 1.1 & -- & 1.0 & .79 & $<.05$ & $<.05$ & $<.05$ & $<.05$ & .06 & .05 \\
\hline \multirow[t]{4}{*}{10} & $<.05$ & .07 & $<.05$ & $<.50$ & $<.05$ & $<.05$ & $<.05$ & $<.05$ & -- & $<.05$ & $<.05$ \\
\hline & 3.6 & .17 & $<.05$ & $<.50$ & 1.4 & $<.05$ & .34 & $<.05$ & -- & $<.05$ & .05 \\
\hline & 7.8 & 2.0 & .81 & $<.50$ & 1.7 & .15 & $<.05$ & $<.05$ & -- & $<.05$ & .06 \\
\hline & 6.1 & .65 & -- & - & 1.3 & $<.05$ & $<.05$ & $<.05$ & $<.05$ & $<.05$ & $<.05$ \\
\hline \multirow[t]{4}{*}{11} & $<.05$ & .05 & $<.05$ & $<.50$ & .05 & $<.05$ & $<.05$ & $<.05$ & -- & $<.05$ & $<.05$ \\
\hline & .92 & .29 & $<.05$ & $<.50$ & 11 & .61 & $<.05$ & $<.05$ & -- & .23 & 4.8 \\
\hline & 2.7 & 1.0 & -- & 1.0 & 18 & .39 & .12 & $<.05$ & $<.05$ & .38 & 7.2 \\
\hline & 1.1 & .50 & -- & 1.0 & 15 & .56 & $<.05$ & .25 & .28 & .46 & 4.2 \\
\hline \multirow[t]{5}{*}{12} & $<.05$ & $<.05$ & $<.05$ & $<.50$ & $<.05$ & $<.05$ & $<.05$ & $<.05$ & -- & $<.05$ & $<.05$ \\
\hline & $<.05$ & $<.05$ & $<.05$ & $<.50$ & .05 & $<.05$ & $<.05$ & $<.05$ & -- & $<.05$ & $<.05$ \\
\hline & 3.1 & 1.3 & $<.05$ & $<.50$ & 2.8 & $<.05$ & .06 & $<.05$ & -- & .18 & 3.3 \\
\hline & 11 & 2.9 & -- & - & 6.4 & .54 & $<.05$ & $<.05$ & $<.05$ & .20 & 3.4 \\
\hline & 10 & 2.9 & -- & -- & 6.6 & .54 & $<.05$ & $<.05$ & $<.05$ & .20 & 3.5 \\
\hline
\end{tabular}


Table 6. Analytical results for selected herbicides and six metabolites in water

\begin{tabular}{|c|c|c|c|c|c|c|c|c|c|c|}
\hline \multirow[b]{2}{*}{$\begin{array}{c}\text { Map } \\
\text { no. } \\
\text { (flg. 1) }\end{array}$} & \multirow[b]{2}{*}{ Site name } & \multirow[b]{2}{*}{$\begin{array}{c}\text { Date of } \\
\text { collec- } \\
\text { tion } \\
\text { (month/ } \\
\text { dayl } \\
\text { year) }\end{array}$} & \multirow[b]{2}{*}{$\begin{array}{c}\text { Sam- } \\
\text { ple } \\
\text { type }\end{array}$} & \multirow[b]{2}{*}{$\begin{array}{l}\text { Aceto- } \\
\text { chlor }\end{array}$} & \multicolumn{6}{|c|}{ Concentration, in micrograms per liter } \\
\hline & & & & & $\begin{array}{l}\text { Ala- } \\
\text { chlor }\end{array}$ & $\begin{array}{l}\text { Ala- } \\
\text { chlor } \\
\text { ethane } \\
\text { sul- } \\
\text { fonlc } \\
\text { acid }\end{array}$ & $\begin{array}{c}\text { Ame- } \\
\text { tryn }\end{array}$ & $\begin{array}{l}\text { Atra- } \\
\text { zine }\end{array}$ & $\begin{array}{l}\text { De- } \\
\text { ethyl- } \\
\text { atra- } \\
\text { zine }\end{array}$ & $\begin{array}{c}\text { Deiso- } \\
\text { propyl- } \\
\text { atra- } \\
\text { zine }\end{array}$ \\
\hline & & & & & & & & & Illinois- & Continued \\
\hline \multirow[t]{2}{*}{13} & South Branch Kishwaukee & $03 / 29 / 94$ & $\mathbf{R}$ & $<0.05$ & $<0.05$ & 3.2 & $<0.05$ & 0.33 & 0.25 & 0.09 \\
\hline & River at Fairdale & $06 / 25 / 94$ & $\mathbf{R}$ & .42 & 1.9 & 11 & $<.05$ & 6.2 & 1.1 & .43 \\
\hline \multirow[t]{3}{*}{14} & Iroquois River near & $03 / 30 / 94$ & $\mathbf{R}$ & $<.05$ & .05 & 2.7 & $<.05$ & .22 & .07 & .14 \\
\hline & Chebanese & $06 / 16 / 94$ & $\mathbf{R}$ & $<.05$ & 1.1 & 5.3 & $<.05$ & 4.2 & .69 & .55 \\
\hline & & $07 / 03 / 95$ & $\mathbf{R}$ & .42 & .13 & 5.2 & $<.05$ & 5.2 & 1.1 & .86 \\
\hline \multirow[t]{3}{*}{15} & Dupage River near & $03 / 30 / 94$ & $\mathbf{R}$ & $<.05$ & $<.05$ & .34 & $<.05$ & $<.05$ & $<.05$ & $<.05$ \\
\hline & Shorwood & $06 / 14 / 94$ & $\mathbf{R}$ & $<.05$ & .52 & 1.5 & $<.05$ & 2.7 & .46 & .21 \\
\hline & & $07 / 05 / 95$ & $\mathbf{R}$ & $<.05$ & $<.05$ & .27 & $<.05$ & .28 & .07 & .19 \\
\hline \multirow[t]{5}{*}{16} & Spoon River at London Mills & $03 / 29 / 94$ & $\mathbf{R}$ & $<.05$ & $<.05$ & .62 & $<.05$ & .17 & .11 & .08 \\
\hline & & $03 / 29 / 94$ & B & $<.05$ & $<.05$ & .57 & $<.05$ & .18 & .11 & .06 \\
\hline & & $05 / 07 / 94$ & B & .18 & .16 & 1.0 & $<.05$ & 3.5 & .31 & .46 \\
\hline & & $05 / 07 / 94$ & $\mathbf{R}$ & .15 & .15 & .90 & $<.05$ & 3.6 & .31 & .43 \\
\hline & & $07 / 06 / 95$ & $\mathbf{R}$ & .48 & .06 & 2.3 & $<.05$ & 6.0 & .85 & .66 \\
\hline \multirow[t]{3}{*}{17} & Sangamon River at Riverton & $03 / 25 / 94$ & $\mathbf{R}$ & $<.05$ & $<.05$ & 1.5 & $<.05$ & .22 & .11 & .12 \\
\hline & & $05 / 10 / 94$ & $\mathbf{R}$ & .54 & .84 & 3.8 & $<.05$ & 4.4 & .35 & .36 \\
\hline & & $06 / 23 / 95$ & $\mathbf{R}$ & .29 & .27 & 2.0 & $<.05$ & 6.0 & .88 & .71 \\
\hline 18 & Macoupin Creek near Kane & $03 / 24 / 94$ & $\mathbf{R}$ & $<.05$ & $<.05$ & .81 & $<.05$ & .28 & .11 & .10 \\
\hline \multirow[t]{3}{*}{19} & Kaskaskia River near & $03 / 24 / 94$ & $\mathbf{R}$ & $<.05$ & $<.05$ & .91 & $<.05$ & .26 & .16 & .13 \\
\hline & Cowden & $06 / 13 / 94$ & $\mathbf{R}$ & .22 & 2.1 & 7.0 & $<.05$ & 10 & 1.9 & 1.1 \\
\hline & & $06 / 21 / 95$ & $\mathbf{R}$ & .30 & $<.05$ & .86 & $<.05$ & 3.0 & .35 & .25 \\
\hline \multirow[t]{5}{*}{20} & Shoal Creek near Breese & $03 / 24 / 94$ & $\mathbf{R}$ & $<.05$ & .24 & .92 & $<.05$ & 2.3 & 1.1 & .56 \\
\hline & & $06 / 26 / 95$ & $\mathbf{X}$ & .63 & 1.2 & 5.3 & $<.05$ & 13 & 1.7 & 1.2 \\
\hline & & $06 / 30 / 95$ & L & .41 & .65 & 5.4 & $<.05$ & 14 & 2.1 & 1.1 \\
\hline & & $06 / 30 / 95$ & $\mathbf{R}$ & .42 & .65 & 5.2 & $<.05$ & 15 & 2.2 & 1.2 \\
\hline & & & & & & & & & & Indiana \\
\hline \multirow[t]{5}{*}{21} & Whitewater River near & $03 / 29 / 94$ & $\mathbf{R}$ & $<.05$ & .06 & .48 & $<.05$ & .17 & .07 & $<.05$ \\
\hline & Alpine & $06 / 24 / 94$ & $\mathbf{X}$ & $<.05$ & .71 & 1.2 & $<.05$ & .74 & .14 & .08 \\
\hline & & $06 / 27 / 94$ & $\mathbf{R}$ & $<.05$ & .70 & 5.7 & $<.05$ & 3.6 & .84 & .40 \\
\hline & & $06 / 27 / 94$ & $\mathrm{~L}$ & $<.05$ & .72 & 5.4 & $<.05$ & 3.4 & .88 & .37 \\
\hline & & $06 / 03 / 95$ & $\mathbf{R}$ & .79 & .64 & 2.3 & $<.05$ & 13 & .94 & .44 \\
\hline
\end{tabular}




\section{Concentration, in micrograms per liter}

\begin{tabular}{|c|c|c|c|c|c|c|c|c|c|c|c|}
\hline $\begin{array}{c}\text { Map } \\
\text { no. } \\
\text { (fig. 1) }\end{array}$ & $\begin{array}{l}\text { Cyana- } \\
\text { zine }\end{array}$ & $\begin{array}{l}\text { Cyana- } \\
\text { zine } \\
\text { amide }\end{array}$ & $\begin{array}{l}\text { De- } \\
\text { ethyl- } \\
\text { cyana- } \\
\text { zine }\end{array}$ & $\begin{array}{l}\text { De- } \\
\text { ethyl- } \\
\text { cyana- } \\
\text { zine }\end{array}$ & $\begin{array}{l}\text { Meto- } \\
\text { lachlor }\end{array}$ & $\begin{array}{l}\text { Metri- } \\
\text { buzin }\end{array}$ & $\begin{array}{c}\text { Prome- } \\
\text { ton }\end{array}$ & $\begin{array}{c}\text { Prome- } \\
\text { tryn }\end{array}$ & $\begin{array}{l}\text { Propa- } \\
\text { chlor }\end{array}$ & $\begin{array}{l}\text { Propa- } \\
\text { zine }\end{array}$ & $\begin{array}{c}\text { Sima- } \\
\text { zine }\end{array}$ \\
\hline \multirow[t]{2}{*}{13} & $<0.05$ & 0.11 & $<0.05$ & $<0.50$ & 0.05 & $<0.05$ & $<0.05$ & $<0.05$ & -- & $<0.05$ & $<0.05$ \\
\hline & 3.2 & 1.9 & $<.05$ & $<.50$ & 3.5 & $<.05$ & $<.05$ & $<.05$ & -- & $<.05$ & $<.05$ \\
\hline \multirow[t]{3}{*}{14} & .13 & .11 & $<.05$ & $<.50$ & .08 & $<.05$ & $<.05$ & $<.05$ & -- & $<.05$ & $<.05$ \\
\hline & 3.2 & 1.8 & $<.05$ & $<.50$ & 1.1 & $<.05$ & $<.05$ & $<.05$ & -- & $<.05$ & $<.05$ \\
\hline & 5.2 & 3.6 & -- & -- & 1.3 & $<.05$ & .05 & $<.05$ & $<0.05$ & .06 & .05 \\
\hline \multirow[t]{3}{*}{15} & $<.05$ & .06 & $<.05$ & $<.50$ & $<.05$ & $<.05$ & $<.05$ & $<.05$ & -- & $<.05$ & $<.05$ \\
\hline & 4.0 & 1.5 & .43 & $<.50$ & 1.1 & .08 & $<.05$ & $<.05$ & -- & $<.05$ & .43 \\
\hline & .38 & .12 & -- & -- & .07 & $<.05$ & .05 & $<.05$ & $<.05$ & $<.05$ & .13 \\
\hline \multirow[t]{5}{*}{16} & $<.05$ & .07 & $<.05$ & $<.50$ & .24 & $<.05$ & $<.05$ & $<.05$ & -- & $<.05$ & $<.05$ \\
\hline & $<.05$ & .06 & $<.05$ & $<.50$ & .23 & $<.05$ & $<.05$ & $<.05$ & -- & $<.05$ & $<.05$ \\
\hline & 5.6 & 1.5 & .14 & $<.50$ & 1.3 & $<.05$ & $<.05$ & $<.05$ & -- & $<.05$ & .11 \\
\hline & 5.7 & 1.5 & .13 & $<.50$ & 1.3 & $<.05$ & $<.05$ & $<.05$ & -- & $<.05$ & .11 \\
\hline & 4.2 & 1.8 & -- & -- & .74 & $<.05$ & .05 & $<.05$ & $<.05$ & .06 & .08 \\
\hline \multirow[t]{3}{*}{17} & $<.05$ & $<.05$ & $<.05$ & $<.50$ & .22 & $<.05$ & $<.05$ & $<.05$ & -- & $<.05$ & $<.05$ \\
\hline & 3.1 & .78 & .10 & $<.50$ & 3.3 & $<.05$ & $<.05$ & $<.05$ & -- & $<.05$ & .08 \\
\hline & 2.1 & 1.6 & -- & -- & 1.6 & .07 & .06 & $<.05$ & $<.05$ & .06 & .05 \\
\hline 18 & .23 & .07 & $<.05$ & $<.50$ & .05 & $<.05$ & $<.05$ & $<.05$ & -- & $<.05$ & $<.05$ \\
\hline \multirow[t]{3}{*}{19} & $<.05$ & $<.05$ & $<.05$ & $<.50$ & .09 & $<.05$ & $<.05$ & $<.05$ & - & $<.05$ & $<.05$ \\
\hline & 1.7 & .83 & $<.05$ & $<.50$ & 5.6 & .14 & $<.05$ & $<.05$ & -- & .22 & .45 \\
\hline & .30 & .09 & -- & -- & .74 & $<.05$ & .06 & $<.05$ & $<.05$ & $<.05$ & .29 \\
\hline \multirow[t]{4}{*}{20} & $<.05$ & .06 & $<.05$ & $<.50$ & .83 & $<.05$ & .07 & $<.05$ & -- & $<.05$ & .32 \\
\hline & 5.3 & 3.6 & -- & -- & 3.7 & .40 & $<.05$ & $<.05$ & $<.05$ & .15 & .75 \\
\hline & 3.9 & 1.9 & -. & -- & 6.0 & .51 & .07 & $<.05$ & $<.05$ & .15 & .18 \\
\hline & 3.8 & 1.8 & -- & -- & 7.0 & .51 & .08 & $<.05$ & $<.05$ & .15 & .23 \\
\hline \multirow[t]{5}{*}{21} & $<.05$ & .05 & $<.05$ & $<.50$ & $<.05$ & $<.05$ & $<.05$ & $<.05$ & -- & $<.05$ & $<.05$ \\
\hline & .13 & -- & -- & -- & .15 & $<.05$ & .33 & $<.05$ & -- & $<.05$ & .10 \\
\hline & .92 & .57 & $<.05$ & $<.50$ & 1.2 & .09 & $<.05$ & $<.05$ & -- & $<.05$ & .30 \\
\hline & .90 & .62 & $<.05$ & $<.50$ & 1.2 & .09 & $<.05$ & $<.05$ & -- & $<.05$ & .32 \\
\hline & 3.6 & .82 & -- & -- & 3.2 & $<.05$ & .05 & $<.05$ & $<.05$ & .09 & .25 \\
\hline
\end{tabular}


Table 6. Analytical results for selected herbicides and six metabolites in water

\begin{tabular}{|c|c|c|c|c|c|c|c|c|c|c|}
\hline \multirow[b]{2}{*}{$\begin{array}{c}\text { Map } \\
\text { no. } \\
\text { (fig. 1) }\end{array}$} & \multirow[b]{2}{*}{ Site name } & \multirow[b]{2}{*}{$\begin{array}{c}\text { Date of } \\
\text { collec- } \\
\text { tion } \\
\text { (month/ } \\
\text { day/ } \\
\text { year) }\end{array}$} & \multirow[b]{2}{*}{$\begin{array}{l}\text { Sam- } \\
\text { ple } \\
\text { type }\end{array}$} & \multirow[b]{2}{*}{$\begin{array}{l}\text { Aceto- } \\
\text { chlor }\end{array}$} & \multicolumn{6}{|c|}{ Concentration, in micrograms per Ilter } \\
\hline & & & & & $\begin{array}{l}\text { Ala- } \\
\text { chlor }\end{array}$ & $\begin{array}{c}\text { Ala- } \\
\text { chlor } \\
\text { ethane } \\
\text { sul- } \\
\text { fonic } \\
\text { acid }\end{array}$ & $\begin{array}{l}\text { Ame- } \\
\text { trynn }\end{array}$ & $\begin{array}{l}\text { Atra- } \\
\text { zine }\end{array}$ & $\begin{array}{l}\text { De- } \\
\text { ethyl- } \\
\text { atra- } \\
\text { zine }\end{array}$ & $\begin{array}{c}\text { Deiso- } \\
\text { propyl- } \\
\text { atra- } \\
\text { zine }\end{array}$ \\
\hline & & & & & & & & & adiana- & Continued \\
\hline \multirow[t]{3}{*}{22} & Blue River at Fredricksburg & $03 / 21 / 94$ & $\mathbf{R}$ & $<0.05$ & $<0.05$ & 0.10 & $<0.05$ & 0.09 & 0.15 & $<0.05$ \\
\hline & & $05 / 16 / 94$ & $\mathbf{R}$ & $<.05$ & .10 & .66 & $<.05$ & 6.8 & 1.6 & .50 \\
\hline & & $06 / 21 / 95$ & $\mathbf{R}$ & $<.05$ & .05 & .37 & $<.05$ & 2.0 & .38 & .20 \\
\hline \multirow[t]{7}{*}{23} & Eel River near Logansport & $03 / 23 / 94$ & $\mathbf{R}$ & $<.05$ & $<.05$ & 1.4 & $<.05$ & .10 & $<.05$ & $<.05$ \\
\hline & & $06 / 08 / 94$ & $\mathbf{X}$ & $<.05$ & .11 & 1.3 & $<.05$ & .33 & .10 & $<.05$ \\
\hline & & $06 / 14 / 94$ & $\mathbf{R}$ & .32 & 2.9 & 8.4 & $<.05$ & 6.1 & .90 & .31 \\
\hline & & $06 / 14 / 94$ & $\mathbf{L}$ & .28 & 4.4 & 7.3 & $<.05$ & 6.4 & 1.4 & .86 \\
\hline & & $06 / 08 / 95$ & $\mathbf{R}$ & .11 & .46 & 1.5 & $<.05$ & 2.5 & .24 & .17 \\
\hline & & $06 / 08 / 95$ & B & .10 & .42 & 1.5 & $<.05$ & 2.3 & .24 & .14 \\
\hline & & $06 / 08 / 95$ & B & .08 & .41 & 1.6 & $<.05$ & 2.3 & .24 & .13 \\
\hline \multirow[t]{3}{*}{24} & Wildcat Creek near Jerome & $03 / 23 / 94$ & $\mathbf{R}$ & $<.05$ & $<.05$ & 1.7 & $<.05$ & $<.05$ & $<.05$ & $<.05$ \\
\hline & & $05 / 25 / 94$ & $\mathbf{R}$ & .19 & .66 & 3.3 & $<.05$ & 3.8 & .57 & .71 \\
\hline & & $06 / 03 / 95$ & $\mathbf{R}$ & .06 & .06 & 1.8 & $<.05$ & .94 & .18 & .74 \\
\hline \multirow[t]{5}{*}{25} & Wildcat Creek near Lafayette & $03 / 23 / 94$ & $\mathbf{R}$ & $<.05$ & $<.05$ & .62 & $<.05$ & .10 & .05 & $<.05$ \\
\hline & & $03 / 23 / 94$ & B & $<.05$ & $<.05$ & .92 & $<.05$ & .13 & .07 & $<.05$ \\
\hline & & $05 / 25 / 94$ & $\mathbf{X}$ & $<.05$ & .24 & 1.5 & $<.05$ & 3.4 & .41 & .39 \\
\hline & & $06 / 14 / 94$ & $\mathbf{R}$ & $<.05$ & .98 & 3.9 & $<.05$ & 4.8 & 1.3 & .80 \\
\hline & & $06 / 23 / 95$ & $\mathbf{R}$ & $<.05$ & $<.05$ & 1.1 & $<.05$ & 1.5 & .25 & .18 \\
\hline \multirow[t]{5}{*}{26} & White River near Nora & $03 / 22 / 94$ & $\mathbf{R}$ & $<.05$ & $<.05$ & .88 & $<.05$ & .13 & .06 & $<.05$ \\
\hline & & $03 / 22 / 94$ & $\mathrm{~L}$ & $<.05$ & $<.05$ & .79 & $<.05$ & .12 & .06 & $<.05$ \\
\hline & & $05 / 26 / 94$ & $\mathbf{R}$ & $<.05$ & 2.3 & 7.3 & $<.05$ & 3.6 & .64 & .47 \\
\hline & & $05 / 26 / 94$ & $\mathrm{~L}$ & $<.05$ & 2.5 & 6.1 & $<.05$ & 4.3 & .73 & .46 \\
\hline & & $06 / 25 / 95$ & $\mathbf{R}$ & .07 & .05 & 1.4 & $<.05$ & 2.2 & .38 & .49 \\
\hline \multirow[t]{4}{*}{27} & Sugar Creek near Edinburgh & $03 / 21 / 94$ & $\mathbf{R}$ & $<.05$ & $<.05$ & .80 & $<.05$ & .09 & .05 & $<.05$ \\
\hline & & $05 / 16 / 94$ & $\mathbf{R}$ & $<.05$ & 2.0 & 6.0 & $<.05$ & 10 & 1.1 & .67 \\
\hline & & $05 / 16 / 94$ & B & $<.05$ & 2.2 & 6.8 & $<.05$ & 11 & 1.1 & .70 \\
\hline & & $06 / 04 / 95$ & $\mathbf{R}$ & .97 & .23 & 2.8 & $<.05$ & 7.2 & .68 & .30 \\
\hline \multirow[t]{3}{*}{28} & East Fork White River near & $03 / 22 / 94$ & $\mathbf{R}$ & $<.05$ & $<.05$ & .73 & $<.05$ & .08 & .06 & $<.05$ \\
\hline & Bedford & $05 / 16 / 94$ & $\mathbf{R}$ & .09 & .91 & 3.4 & $<.05$ & 5.7 & .78 & .37 \\
\hline & & $06 / 24 / 95$ & $\mathbf{R}$ & .57 & .94 & 4.4 & $<.05$ & 12 & .74 & .42 \\
\hline
\end{tabular}




\section{Concentration, in micrograms per liter}

\begin{tabular}{|c|c|c|c|c|c|c|c|c|c|c|c|}
\hline $\begin{array}{c}\text { Map } \\
\text { no. } \\
\text { (fig. 1) }\end{array}$ & $\begin{array}{l}\text { Cyana- } \\
\text { zine }\end{array}$ & $\begin{array}{l}\text { Cyana- } \\
\text { zine } \\
\text { amide }\end{array}$ & $\begin{array}{l}\text { De- } \\
\text { ethyl- } \\
\text { cyana- } \\
\text { zine }\end{array}$ & $\begin{array}{l}\text { De- } \\
\text { ethyl- } \\
\text { cyana- } \\
\text { zine }\end{array}$ & $\begin{array}{l}\text { Meto- } \\
\text { lachlor }\end{array}$ & $\begin{array}{l}\text { Metri- } \\
\text { buzin }\end{array}$ & $\begin{array}{l}\text { Prome- } \\
\text { ton }\end{array}$ & $\begin{array}{c}\text { Prome- } \\
\text { tryn }\end{array}$ & $\begin{array}{l}\text { Propa- } \\
\text { chlor }\end{array}$ & $\begin{array}{l}\text { Propa- } \\
\text { zine }\end{array}$ & $\begin{array}{l}\text { Sima- } \\
\text { zine }\end{array}$ \\
\hline \multirow[t]{3}{*}{22} & $<0.05$ & $<0.05$ & $<0.05$ & $<0.50$ & $<0.05$ & $<0.05$ & $<0.05$ & $<0.05$ & -- & $<0.05$ & $<0.05$ \\
\hline & 2.0 & .25 & $<.05$ & $<.50$ & 5.0 & $<.05$ & $<.05$ & $<.05$ & -- & $<.05$ & .59 \\
\hline & $<.05$ & $<.05$ & -- & -- & .50 & $<.05$ & $<.05$ & $<.05$ & 0.06 & $<.05$ & .48 \\
\hline \multirow[t]{7}{*}{23} & $<.05$ & .06 & $<.05$ & $<.50$ & $<.05$ & $<.05$ & $<.05$ & $<.05$ & -- & $<.05$ & $<.05$ \\
\hline & .49 & .07 & $<.05$ & $<.50$ & .15 & $<.05$ & $<.05$ & $<.05$ & -- & $<.05$ & .06 \\
\hline & .94 & -- & -- & -- & 1.5 & .09 & $<.05$ & $<.05$ & -- & .05 & .91 \\
\hline & 2.4 & 1.7 & .43 & $<.50$ & 1.9 & .07 & $<.05$ & $<.05$ & -- & $<.05$ & 1.2 \\
\hline & .68 & .20 & -- & -- & .68 & $<.05$ & $<.05$ & $<.05$ & $<.05$ & $<.05$ & .18 \\
\hline & .58 & .18 & -- & -- & .61 & .60 & $<.05$ & $<.05$ & $<.05$ & $<.05$ & .19 \\
\hline & .53 & .14 & -- & -- & .64 & $<.05$ & $<.05$ & $<.05$ & $<.05$ & $<.05$ & .18 \\
\hline \multirow[t]{3}{*}{24} & $<.05$ & .10 & $<.05$ & $<.50$ & .05 & $<.05$ & $<.05$ & $<.05$ & -- & $<.05$ & $<.05$ \\
\hline & 6.2 & 2.7 & .63 & $<.50$ & 3.5 & .28 & $<.05$ & $<.05$ & -- & $<.05$ & $<.05$ \\
\hline & $<.05$ & .67 & -- & -- & .44 & $<.05$ & $<.05$ & $<.05$ & $<0.05$ & $<.05$ & $<.05$ \\
\hline \multirow[t]{5}{*}{25} & $<.05$ & .06 & $<.05$ & $<.50$ & $<.05$ & $<.05$ & $<.05$ & $<.05$ & -- & $<.05$ & $<.05$ \\
\hline & $<.05$ & .07 & $<.05$ & $<.50$ & .06 & $<.05$ & $<.05$ & $<.05$ & -- & $<.05$ & $<.05$ \\
\hline & 3.4 & .55 & .17 & $<.50$ & 1.4 & $<.05$ & $<.05$ & $<.05$ & -- & $<.05$ & .08 \\
\hline & 1.7 & .57 & $<.05$ & $<.50$ & 4.0 & $<.05$ & $<.05$ & $<.05$ & -- & $<.05$ & $<.05$ \\
\hline & .70 & .37 & -- & -- & .46 & $<.05$ & .05 & $<.05$ & $<.05$ & $<.05$ & .05 \\
\hline \multirow[t]{5}{*}{26} & $<.05$ & .08 & $<.05$ & $<.50$ & $<.05$ & $<.05$ & $<.05$ & $<.05$ & -- & $<.05$ & $<.05$ \\
\hline & $<.05$ & .08 & $<.05$ & $<.50$ & $<.05$ & $<.05$ & $<.05$ & $<.05$ & -- & $<.05$ & $<.05$ \\
\hline & 1.0 & .49 & $<.05$ & $<.50$ & 2.0 & .24 & .22 & $<.05$ & -- & $<.05$ & .13 \\
\hline & 2.7 & .63 & $<.05$ & $<.50$ & 1.9 & .29 & .22 & $<.05$ & -- & $<.05$ & .15 \\
\hline & 1.0 & .49 & -- & -- & .90 & $<.05$ & .21 & $<.05$ & $<.05$ & $<.05$ & .08 \\
\hline
\end{tabular}

$\begin{array}{rlllllrllllrr}27 & <.05 & <.05 & <.05 & <.50 & <.05 & <.05 & <.05 & <.05 & - & <.05 & <.05 \\ & 2.1 & 1.0 & <.05 & <.50 & 3.1 & .05 & <.05 & <.05 & - & .05 & .85 \\ & 2.3 & 1.1 & .10 & <.50 & 3.4 & <.05 & <.05 & <.05 & - & .10 & .90 \\ & .98 & .57 & -- & -- & 1.4 & <.05 & <.05 & <.05 & <.05 & .06 & .37 \\ & & & & & & & & & & & \\ 28 & <.05 & .05 & <.05 & <.50 & <.05 & <.05 & <.05 & <.05 & -- & <.05 & <.05 \\ & 1.2 & .36 & <.05 & <.50 & 1.8 & <.05 & <.05 & <.05 & -- & .06 & .77 \\ & <.05 & .24 & -- & -- & .84 & <.05 & <.05 & <.05 & <.05 & .12 & .21\end{array}$


Table 6. Analytical results for selected herbicides and six metabolites in water

\begin{tabular}{|c|c|c|c|c|c|c|c|c|c|c|}
\hline \multirow[b]{2}{*}{$\begin{array}{c}\text { Map } \\
\text { no. } \\
\text { (fig. 1) }\end{array}$} & \multirow[b]{2}{*}{ Site name } & \multirow[b]{2}{*}{$\begin{array}{c}\text { Date of } \\
\text { collec- } \\
\text { tion } \\
\text { (month/ } \\
\text { dayl } \\
\text { year) }\end{array}$} & \multirow[b]{2}{*}{$\begin{array}{l}\text { Sam- } \\
\text { ple } \\
\text { type }\end{array}$} & \multirow[b]{2}{*}{$\begin{array}{l}\text { Aceto- } \\
\text { chlor }\end{array}$} & \multicolumn{6}{|c|}{ Concentration, in micrograms per liter } \\
\hline & & & & & $\begin{array}{l}\text { Ala- } \\
\text { chlor }\end{array}$ & $\begin{array}{c}\text { Ala- } \\
\text { chlor } \\
\text { ethane } \\
\text { sui- } \\
\text { fonic } \\
\text { acid }\end{array}$ & $\begin{array}{l}\text { Ame- } \\
\text { tryn }\end{array}$ & $\begin{array}{l}\text { Atra- } \\
\text { zine }\end{array}$ & $\begin{array}{l}\text { De- } \\
\text { ethyl- } \\
\text { atra- } \\
\text { zine }\end{array}$ & $\begin{array}{c}\text { Deiso- } \\
\text { propyl- } \\
\text { atra- } \\
\text { zine }\end{array}$ \\
\hline & & & & & & & & & & $\overline{\text { Kansas }}$ \\
\hline \multirow[t]{4}{*}{29} & Black Vermillion River near & $03 / 22 / 94$ & $\mathbf{R}$ & $<0.05$ & $<0.05$ & 0.72 & $<0.05$ & 0.16 & 0.05 & $<0.05$ \\
\hline & Frankfort & $05 / 14 / 94$ & $\mathbf{R}$ & $<.05$ & 4.9 & 5.6 & $<.05$ & 12 & .71 & .41 \\
\hline & & $05 / 14 / 94$ & $\mathbf{L}$ & $<.05$ & 5.6 & 7.3 & $<.05$ & 12 & .74 & .38 \\
\hline & & $06 / 24 / 95$ & $\mathbf{R}$ & $<.05$ & .72 & 1.2 & $<.05$ & 36 & 1.1 & .51 \\
\hline \multirow[t]{4}{*}{30} & Delaware River near & $03 / 21 / 94$ & $\mathbf{R}$ & $<.05$ & $<.05$ & .49 & $<.05$ & .17 & $<.05$ & $<.05$ \\
\hline & Muscotah & $05 / 15 / 94$ & $\mathbf{R}$ & .31 & 3.0 & 5.2 & $<.05$ & 16 & .85 & .44 \\
\hline & & $06 / 25 / 95$ & $\mathbf{R}$ & .19 & 5.3 & 12 & $<.05$ & 21 & 1.2 & .49 \\
\hline & & & & & & & & & \multicolumn{2}{|r|}{ Minnesota } \\
\hline \multirow[t]{3}{*}{31} & Cottonwood River near New & $04 / 05 / 94$ & $\mathbf{R}$ & $<.05$ & $<.05$ & 1.1 & $<.05$ & .05 & $<.05$ & $<.05$ \\
\hline & Ulm & $05 / 25 / 94$ & $\mathbf{R}$ & .48 & 4.5 & 6.8 & $<.05$ & 3.7 & .38 & 1.1 \\
\hline & & $05 / 28 / 95$ & $\mathbf{R}$ & .07 & .06 & 1.1 & $<.05$ & .06 & $<.05$ & .14 \\
\hline \multirow[t]{3}{*}{32} & Des Moines River at Jackson & $04 / 05 / 94$ & $\mathbf{R}$ & $<.05$ & $<.05$ & 1.5 & $<.05$ & .18 & .06 & $<.05$ \\
\hline & & $06 / 06 / 94$ & $\mathbf{R}$ & .10 & .33 & 2.1 & $<.05$ & 2.2 & .31 & .16 \\
\hline & & $05 / 28 / 95$ & $\mathbf{R}$ & .28 & .05 & 1.6 & $<.05$ & .16 & .08 & .11 \\
\hline \multirow[t]{5}{*}{33} & Rock River at Luverne & 04/04/94 & $\mathbf{R}$ & $<.05$ & $<.05$ & .69 & $<.05$ & .06 & $<.05$ & $<.05$ \\
\hline & & $04 / 04 / 94$ & $\mathbf{L}$ & $<.05$ & $<.05$ & .74 & $<.05$ & .07 & $<.05$ & $<.05$ \\
\hline & & $06 / 06 / 94$ & $\mathbf{R}$ & 1.0 & 1.9 & 5.4 & $<.05$ & 8.9 & .81 & .33 \\
\hline & & $05 / 28 / 95$ & $\mathbf{R}$ & 6.0 & .10 & 1.0 & $<.05$ & 1.2 & .17 & .10 \\
\hline & & & & & & & & & & Missouri \\
\hline \multirow[t]{3}{*}{34} & Nodaway River near Graham & $03 / 29 / 94$ & $\mathbf{R}$ & $<.05$ & $<.05$ & .39 & $<.05$ & .06 & $<.05$ & $<.05$ \\
\hline & & $06 / 02 / 94$ & $\mathbf{R}$ & $<.05$ & 3.4 & 6.5 & $<.05$ & 16 & 1.9 & 1.2 \\
\hline & & & & & & & & & \multicolumn{2}{|r|}{ Nebraska } \\
\hline \multirow[t]{10}{*}{35} & Salt Creek at Roca & $03 / 29 / 94$ & $\mathbf{R}$ & $<.05$ & $<.05$ & .69 & $<.05$ & .26 & .10 & $<.05$ \\
\hline & & $03 / 29 / 94$ & B & $<.05$ & $<.05$ & .72 & $<.05$ & .32 & .12 & .06 \\
\hline & & $05 / 15 / 94$ & $\mathbf{R}$ & 1.0 & 6.5 & 18 & $<.05$ & 26 & 1.7 & .87 \\
\hline & & $05 / 15 / 94$ & $\mathrm{~L}$ & 2.0 & 7.2 & 14 & $<.05$ & 26 & 2.1 & 1.0 \\
\hline & & $07 / 04 / 95$ & $\mathbf{R}$ & .08 & 1.4 & 1.6 & $<.05$ & 28 & 2.2 & 1.5 \\
\hline & & $07 / 04 / 95$ & B & .09 & 1.4 & 1.7 & $<.05$ & 30 & 2.5 & 1.8 \\
\hline & & $07 / 04 / 95$ & 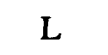 & .10 & 1.6 & -- & $<.05$ & 31 & 2.8 & 1.6 \\
\hline & & $07 / 25 / 95$ & $\mathrm{~T}$ & $<.05$ & $<.05$ & 1.1 & $<.05$ & .91 & .16 & .10 \\
\hline & & 08/08/95 & $\mathrm{T}$ & $<.05$ & .54 & 4.5 & $<.05$ & 3.3 & .54 & .32 \\
\hline & & 09/02/95 & $\mathrm{T}$ & $<.05$ & $<.05$ & .69 & $<.05$ & .20 & .06 & $<.05$ \\
\hline
\end{tabular}




\section{Concentration, in micrograms per liter}

\begin{tabular}{|c|c|c|c|c|c|c|c|c|c|c|c|}
\hline $\begin{array}{c}\text { Map } \\
\text { no. } \\
\text { (fig. 1) }\end{array}$ & $\begin{array}{l}\text { Cyana- } \\
\text { zine }\end{array}$ & $\begin{array}{l}\text { Cyana- } \\
\text { zine } \\
\text { amide }\end{array}$ & $\begin{array}{l}\text { De- } \\
\text { ethyl- } \\
\text { cyana- } \\
\text { zine }\end{array}$ & $\begin{array}{l}\text { De- } \\
\text { ethyl- } \\
\text { cyana- } \\
\text { zine }\end{array}$ & $\begin{array}{l}\text { Meto- } \\
\text { lachlor }\end{array}$ & $\begin{array}{l}\text { Metri- } \\
\text { buzin }\end{array}$ & $\begin{array}{l}\text { Prome- } \\
\text { ton }\end{array}$ & $\begin{array}{c}\text { Prome- } \\
\text { tryn }\end{array}$ & $\begin{array}{l}\text { Propa- } \\
\text { chlor }\end{array}$ & $\begin{array}{l}\text { Propa- } \\
\text { zine }\end{array}$ & $\begin{array}{c}\text { Sima- } \\
\text { zine }\end{array}$ \\
\hline \multirow[t]{4}{*}{29} & $<0.05$ & $<0.05$ & $<0.05$ & $<0.50$ & $<0.05$ & $<0.05$ & $<0.05$ & $<0.05$ & -- & $<0.05$ & $<0.05$ \\
\hline & $<.05$ & $<.05$ & $<.05$ & $<.50$ & 4.8 & 1.2 & $<.05$ & $<.05$ & -- & $<.05$ & $<.05$ \\
\hline & $<.05$ & $<.05$ & $<.05$ & $<.50$ & 5.4 & 1.2 & $<.05$ & $<.05$ & -- & .14 & $<.05$ \\
\hline & $<.05$ & $<.05$ & -- & 1.0 & 7.3 & .30 & $<.05$ & $<.05$ & 6.3 & .29 & .05 \\
\hline \multirow[t]{3}{*}{30} & $<.05$ & $<.05$ & $<.05$ & $<.50$ & $<.05$ & $<.05$ & $<.05$ & $<.05$ & -- & $<.05$ & $<.05$ \\
\hline & 3.3 & .31 & $<.05$ & $<.50$ & 7.2 & $<.05$ & $<.05$ & $<.05$ & -- & .10 & $<.05$ \\
\hline & .20 & .13 & -- & -- & 9.3 & .96 & $<.05$ & $<.05$ & 7.9 & .15 & $<.05$ \\
\hline \multirow[t]{3}{*}{31} & $<.05$ & .11 & $<.05$ & $<.50$ & .05 & $<.05$ & $<.05$ & $<.05$ & -- & $<.05$ & $<.05$ \\
\hline & 56 & 4.0 & 2.0 & .28 & 1.2 & $<.05$ & $<.05$ & $<.05$ & -- & $<.05$ & .10 \\
\hline & .17 & .12 & -- & -- & .28 & $<.05$ & $<.05$ & $<.05$ & $<.05$ & $<.05$ & $<.05$ \\
\hline \multirow[t]{3}{*}{32} & $<.05$ & .09 & $<.05$ & $<.50$ & .08 & $<.05$ & $<.05$ & $<.05$ & -- & $<.05$ & $<.05$ \\
\hline & .93 & .22 & $<.05$ & $<.50$ & .12 & $<.05$ & $<.05$ & $<.05$ & -- & $<.05$ & $<.05$ \\
\hline & .38 & .15 & -- & -- & .22 & $<.05$ & $<.05$ & $<.05$ & $<.05$ & $<.05$ & $<.05$ \\
\hline \multirow[t]{4}{*}{33} & $<.05$ & $<.05$ & $<.05$ & $<.50$ & .05 & $<.05$ & $<.05$ & $<.05$ & -- & $<.05$ & $<.05$ \\
\hline & $<.05$ & $<.05$ & $<.05$ & $<.50$ & .05 & $<.05$ & $<.05$ & $<.05$ & -- & $<.05$ & $<.05$ \\
\hline & 3.2 & .78 & $<.05$ & $<.50$ & 5.3 & .20 & $<.05$ & $<.05$ & -- & .20 & .07 \\
\hline & 2.1 & .17 & -- & 1.0 & 11 & $<.05$ & $<.05$ & $<.05$ & $<.05$ & $<.05$ & $<.05$ \\
\hline \multirow[t]{2}{*}{34} & $<.05$ & $<.05$ & $<.05$ & $<.50$ & $<.05$ & $<.05$ & $<.05$ & $<.05$ & -- & $<.05$ & $<.05$ \\
\hline & 18 & 6.4 & $<.05$ & $<.50$ & 3.1 & .37 & $<.05$ & $<.05$ & -- & .23 & .27 \\
\hline \multirow[t]{10}{*}{35} & $<.05$ & .05 & $<.05$ & $<.50$ & $<.05$ & $<.05$ & $<.05$ & $<.05$ & -- & $<.05$ & $<.05$ \\
\hline & $<.05$ & $<.05$ & $<.05$ & $<: 50$ & $<.05$ & $<.05$ & $<.05$ & $<.05$ & -- & $<.05$ & $<.05$ \\
\hline & 11 & 2.3 & $<.05$ & $<.50$ & 6.3 & 1.7 & $<.05$ & $<.05$ & -- & .27 & .08 \\
\hline & 14 & 1.7 & $<.05$ & $<.50$ & 7.3 & 2.1 & $<.05$ & $<.05$ & -- & .36 & $<.05$ \\
\hline & 1.3 & .45 & -- & 1.0 & 19 & 1.4 & $<.05$ & $<.05$ & 5.3 & .33 & $<.05$ \\
\hline & 1.3 & .45 & -- & 2.0 & 20 & 1.5 & $<.05$ & $<.05$ & 6.8 & .36 & .06 \\
\hline & 1.4 & .49 & -- & 2.0 & 22 & 1.6 & $<.05$ & $<.05$ & 5.0 & .35 & $<.05$ \\
\hline & .25 & .11 & -- & -- & .22 & $<.05$ & $<.05$ & $<.05$ & $<.05$ & $<.05$ & $<.05$ \\
\hline & .36 & .25 & -- & -- & .52 & $<.05$ & $<.05$ & $<.05$ & $<.05$ & $<.05$ & $<.05$ \\
\hline & $<.05$ & $<.05$ & -- & -- & .07 & $<.05$ & .05 & $<.05$ & $<.05$ & $<.05$ & $<.05$ \\
\hline
\end{tabular}


Table 6. Analytical results for selected herbicides and six metabolites in water

\begin{tabular}{|c|c|c|c|c|c|c|c|c|c|c|}
\hline \multirow[b]{2}{*}{$\begin{array}{c}\text { Map } \\
\text { no. } \\
\text { (fig. 1) }\end{array}$} & \multirow[b]{2}{*}{ Site name } & \multirow[b]{2}{*}{$\begin{array}{l}\text { Date of } \\
\text { collec- } \\
\text { tion } \\
\text { (month/ } \\
\text { dayl } \\
\text { year) }\end{array}$} & \multirow[b]{2}{*}{$\begin{array}{l}\text { Sam- } \\
\text { ple } \\
\text { type }\end{array}$} & \multirow[b]{2}{*}{$\begin{array}{l}\text { Aceto- } \\
\text { chlor }\end{array}$} & \multicolumn{6}{|c|}{ Concentration, in micrograms per liter } \\
\hline & & & & & $\begin{array}{l}\text { Ala- } \\
\text { chlor }\end{array}$ & $\begin{array}{c}\text { Ala- } \\
\text { chlor } \\
\text { ethane } \\
\text { sul- } \\
\text { fonic } \\
\text { acid }\end{array}$ & $\begin{array}{l}\text { Ame- } \\
\text { tryn }\end{array}$ & $\begin{array}{l}\text { Atra- } \\
\text { zine }\end{array}$ & $\begin{array}{l}\text { De- } \\
\text { ethyl- } \\
\text { atra- } \\
\text { zine }\end{array}$ & $\begin{array}{c}\text { Deiso- } \\
\text { propyl- } \\
\text { atra- } \\
\text { zine }\end{array}$ \\
\hline & & & & & & & & \multicolumn{3}{|c|}{ Nebraska-Continued } \\
\hline 35 & Salt Creek at Roca-Continued & 09/02/95 & $\mathbf{T}$ & $<0.05$ & $<0.05$ & 0.43 & $<0.05$ & 0.15 & 0.06 & 0.06 \\
\hline \multirow[t]{3}{*}{36} & Wahoo Creek at Itica & $03 / 29 / 94$ & $\mathbf{R}$ & $<.05$ & $<.05$ & .28 & $<.05$ & .07 & $<.05$ & $<.05$ \\
\hline & & 06/02/94 & $\mathbf{R}$ & $<.05$ & 10 & 8.2 & $<.05$ & 28 & 2.0 & 1.9 \\
\hline & & $07 / 04 / 95$ & $\mathbf{R}$ & $<.05$ & .07 & .21 & $<.05$ & .64 & .08 & .07 \\
\hline \multirow[t]{3}{*}{37} & West Fork Big Blue River & $03 / 29 / 94$ & $\mathbf{R}$ & $<.05$ & $<.05$ & .51 & $<.05$ & .16 & .08 & $<.05$ \\
\hline & near Dorchester & $06 / 27 / 94$ & $\mathbf{R}$ & $<.05$ & 3.1 & 15 & $<.05$ & 15 & 2.4 & 1.5 \\
\hline & & $06 / 09 / 95$ & $\mathbf{R}$ & 5.6 & 2.0 & 4.1 & $<.05$ & 45 & 3.4 & 2.0 \\
\hline \multirow[t]{5}{*}{38} & Big Nemaha at Fall City & 03/30/94 & $\mathbf{R}$ & $<.05$ & $<.05$ & .32 & $<.05$ & .14 & $<.05$ & $<.05$ \\
\hline & & $05 / 15 / 94$ & $\mathbf{R}$ & .97 & 8.1 & 9.7 & $<.05$ & 23 & 1.2 & .57 \\
\hline & & $05 / 15 / 94$ & B & .87 & 7.2 & 5.2 & $<.05$ & 24 & 1.0 & .51 \\
\hline & & $06 / 26 / 95$ & $\mathbf{R}$ & $<.05$ & 5.8 & 6.6 & $<.05$ & 43 & 1.8 & .62 \\
\hline & & $06 / 26 / 95$ & $\mathbf{L}$ & $<.05$ & 5.3 & 7.0 & $<.05$ & 40 & 1.7 & .71 \\
\hline \multirow[t]{3}{*}{39} & Big Blue River at Barneston & $03 / 30 / 94$ & $\mathbf{R}$ & $<.05$ & $<.05$ & .71 & $<.05$ & .16 & .07 & $<.05$ \\
\hline & & $05 / 15 / 94$ & $\mathbf{R}$ & .09 & 7.9 & 15 & $<.05$ & 25 & 1.3 & .73 \\
\hline & & $06 / 26 / 95$ & $\mathbf{R}$ & 1.3 & 20 & 23 & $<.05$ & 47 & 2.1 & .77 \\
\hline \multirow[t]{4}{*}{40} & Little Blue River near & $03 / 30 / 94$ & $\mathbf{R}$ & $<.05$ & $<.05$ & .28 & $<.05$ & .22 & .08 & $<.05$ \\
\hline & Fairbury & $06 / 02 / 94$ & $\mathbf{R}$ & $<.05$ & 7.9 & 4.3 & $<.05$ & 20 & 1.4 & .58 \\
\hline & & $06 / 02 / 94$ & $\mathbf{L}$ & $<.05$ & 6.6 & 6.6 & $<.05$ & 16 & 1.1 & .41 \\
\hline & & $06 / 26 / 95$ & $\mathbf{R}$ & 2.4 & 5.3 & 9.6 & $<.05$ & 27 & 1.8 & 1.01 \\
\hline \multirow[t]{5}{*}{41} & Clear Creek near Rockbridge & $03 / 28 / 94$ & $\mathbf{R}$ & $<.05$ & $<.05$ & .44 & $<.05$ & .10 & .06 & .05 \\
\hline & & $06 / 21 / 94$ & $\mathbf{R}$ & $<.05$ & $<.05$ & .25 & $<.05$ & 1.3 & .17 & .15 \\
\hline & & $05 / 25 / 95$ & $\mathbf{R}$ & .96 & .06 & .28 & $<.05$ & 6.9 & .26 & .21 \\
\hline & & $06 / 01 / 95$ & $\mathrm{XD}$ & .07 & $<.05$ & .33 & $<.05$ & .90 & .13 & .10 \\
\hline & & $06 / 01 / 95$ & $\mathbf{X}$ & .07 & $<.05$ & .28 & $<.05$ & .88 & .12 & .10 \\
\hline \multirow[t]{4}{*}{42} & Scioto River near Prospect & $03 / 25 / 94$ & $\mathbf{R}$ & $<.05$ & .05 & 2.5 & $<.05$ & .16 & .06 & $<.05$ \\
\hline & & $03 / 25 / 94$ & L & $<.05$ & $<.05$ & 2.4 & $<.05$ & .14 & .05 & $<.05$ \\
\hline & & $06 / 15 / 94$ & $\mathbf{R}$ & $<.05$ & 3.8 & 5.6 & $<.05$ & 21 & 3.5 & 1.3 \\
\hline & & $05 / 30 / 95$ & $\mathbf{R}$ & 1.1 & .25 & 2.0 & $<.05$ & 12 & .90 & .60 \\
\hline
\end{tabular}




\begin{tabular}{|c|c|c|c|c|c|c|c|c|c|c|c|}
\hline $\begin{array}{c}\text { Map } \\
\text { no. } \\
\text { (fig. 1) }\end{array}$ & $\begin{array}{l}\text { Cyana- } \\
\text { zine }\end{array}$ & $\begin{array}{l}\text { Cyana- } \\
\text { zine } \\
\text { amide }\end{array}$ & $\begin{array}{l}\text { De- } \\
\text { ethyl- } \\
\text { cyana- } \\
\text { zine }\end{array}$ & $\begin{array}{l}\text { De- } \\
\text { ethyl- } \\
\text { cyana- } \\
\text { zine }\end{array}$ & $\begin{array}{l}\text { Meto- } \\
\text { lachlor }\end{array}$ & $\begin{array}{l}\text { Metri- } \\
\text { buzin }\end{array}$ & $\begin{array}{c}\text { Prome- } \\
\text { ton }\end{array}$ & $\begin{array}{l}\text { Prome- } \\
\text { tryn }\end{array}$ & $\begin{array}{l}\text { Propa- } \\
\text { chlor }\end{array}$ & $\begin{array}{l}\text { Propa- } \\
\text { zine }\end{array}$ & $\begin{array}{c}\text { Sima- } \\
\text { zine }\end{array}$ \\
\hline 35 & $<0.05$ & $<0.05$ & -- & -- & 0.05 & $<0.05$ & $<0.05$ & $<0.05$ & $<0.05$ & $<0.05$ & $<0.05$ \\
\hline \multirow[t]{3}{*}{36} & $<.05$ & .06 & $<0.05$ & $<0.50$ & $<.05$ & $<.05$ & $<.05$ & $<.05$ & -- & $<.05$ & $<.05$ \\
\hline & 20 & 5.4 & 2.6 & .71 & 7.0 & 1.9 & $<.05$ & $<.05$ & -- & $<.05$ & $<.05$ \\
\hline & .60 & $<.05$ & -- & -- & .24 & $<.05$ & $<.05$ & $<.05$ & .05 & $<.05$ & $<.05$ \\
\hline \multirow[t]{3}{*}{37} & $<.05$ & $<.05$ & $<.05$ & $<.50$ & .05 & $<.05$ & $<.05$ & $<.05$ & -- & $<.05$ & $<.05$ \\
\hline & 1.5 & .77 & $<.05$ & $<.50$ & 3.1 & .11 & $<.05$ & $<.05$ & -- & .22 & .09 \\
\hline & 1.2 & .28 & -- & -- & 7.9 & .13 & .15 & $<.05$ & .13 & .34 & .19 \\
\hline \multirow[t]{5}{*}{38} & $<.05$ & $<.05$ & $<.05$ & $<.50$ & .05 & $<.05$ & $<.05$ & $<.05$ & -- & $<.05$ & $<.05$ \\
\hline & 7.1 & .38 & $<.05$ & $<.50$ & 8.2 & 1.5 & $<.05$ & $<.05$ & -- & .11 & $<.05$ \\
\hline & 6.4 & .30 & $<.05$ & $<.50$ & 11 & 1.4 & $<.05$ & $<.05$ & -- & .11 & $<.05$ \\
\hline & 2.1 & .29 & -- & 1.0 & 16 & 1.3 & $<.05$ & $<.05$ & 1.8 & .30 & $<.05$ \\
\hline & 2.1 & .29 & -- & 1.0 & 17 & 1.2 & $<.05$ & $<.05$ & 2.0 & .25 & $<.05$ \\
\hline \multirow[t]{3}{*}{39} & $<.05$ & $<.05$ & $<.05$ & $<.50$ & $<.05$ & $<.05$ & $<.05$ & $<.05$ & -- & $<.05$ & $<.05$ \\
\hline & 6.1 & .85 & $<.05$ & $<.50$ & 4.6 & 1.3 & $<.05$ & $<.05$ & -- & .11 & .14 \\
\hline & .66 & .15 & -- & 1.0 & 19 & .43 & .15 & $<.05$ & 4.1 & .47 & .09 \\
\hline \multirow[t]{4}{*}{40} & $<.05$ & $<.05$ & $<.05$ & $<.50$ & $<.05$ & $<.05$ & $<.05$ & $<.05$ & -- & $<.05$ & $<.05$ \\
\hline & .27 & $<.05$ & $<.05$ & $<.50$ & 6.0 & $<.05$ & $<.05$ & $<.05$ & -- & .30 & $<.05$ \\
\hline & .17 & $<.05$ & $<.05$ & $<.50$ & 5.1 & $<.05$ & $<.05$ & $<.05$ & -- & .22 & .11 \\
\hline & .21 & .08 & -- & -- & 5.6 & .25 & $<.05$ & $<.05$ & .21 & .21 & .09 \\
\hline \multirow[t]{5}{*}{41} & $<.05$ & $<.05$ & $<.05$ & $<.50$ & .20 & $<.05$ & $<.05$ & $<.05$ & -- & $<.05$ & .07 \\
\hline & .36 & .16 & $<.05$ & $<.50$ & .33 & $<.05$ & $<.05$ & $<.05$ & -- & $<.05$ & .16 \\
\hline & .58 & .29 & -- & -- & 1.7 & .08 & .07 & $<.05$ & $<.05$ & .05 & .73 \\
\hline & .27 & .24 & -- & -- & .31 & $<.05$ & $<.05$ & $<.05$ & $<.05$ & $<.05$ & .23 \\
\hline & .26 & .25 & -- & -- & .29 & $<.05$ & $<.05$ & $<.05$ & $<.05$ & $<.05$ & .23 \\
\hline \multirow[t]{4}{*}{42} & $<.05$ & .06 & $<.05$ & $<.50$ & .18 & $<.05$ & $<.05$ & $<.05$ & -- & $<.05$ & $<.05$ \\
\hline & $<.05$ & .06 & $<.05$ & $<.50$ & .16 & $<.05$ & $<.05$ & $<.05$ & -- & $<.05$ & $<.05$ \\
\hline & 9.2 & 1.7 & $<.05$ & $<.50$ & 4.0 & 1.0 & $<.05$ & $<.05$ & - & .49 & $<.05$ \\
\hline & 8.9 & 2.0 & -- & -- & 6.6 & .18 & .11 & $<.05$ & $<.05$ & .10 & .45 \\
\hline
\end{tabular}


Table 6. Analytical results for selected herbicides and six metabolites in water

\begin{tabular}{|c|c|c|c|c|c|c|c|c|c|c|}
\hline \multirow[b]{2}{*}{$\begin{array}{c}\text { Map } \\
\text { no. } \\
\text { (fig. 1) }\end{array}$} & \multirow[b]{2}{*}{ Site name } & \multirow[b]{2}{*}{$\begin{array}{c}\text { Date of } \\
\text { collec- } \\
\text { tion } \\
\text { (month/ } \\
\text { dayl } \\
\text { year) }\end{array}$} & \multirow[b]{2}{*}{$\begin{array}{l}\text { Sam- } \\
\text { ple } \\
\text { type }\end{array}$} & \multirow[b]{2}{*}{$\begin{array}{l}\text { Aceto- } \\
\text { chlor }\end{array}$} & \multicolumn{6}{|c|}{ Concentration, in micrograms per liter } \\
\hline & & & & & $\begin{array}{l}\text { Ala- } \\
\text { chlor }\end{array}$ & $\begin{array}{l}\text { Ala- } \\
\text { chlor } \\
\text { ethane } \\
\text { sul- } \\
\text { fonic } \\
\text { acid }\end{array}$ & $\begin{array}{c}\text { Ame- } \\
\text { tryn }\end{array}$ & $\begin{array}{l}\text { Atra- } \\
\text { zine }\end{array}$ & $\begin{array}{l}\text { De- } \\
\text { ethyl- } \\
\text { atra- } \\
\text { zine }\end{array}$ & $\begin{array}{c}\text { Deiso- } \\
\text { propyl- } \\
\text { atra- } \\
\text { zine }\end{array}$ \\
\hline & & & & & & & & & Ohio- & Continued \\
\hline \multirow[t]{4}{*}{43} & Olentangy River at Claridon & $03 / 25 / 94$ & $\mathbf{R}$ & $<0.05$ & 0.05 & 3.1 & $<0.05$ & 0.22 & 0.10 & $<0.05$ \\
\hline & & $06 / 24 / 94$ & $\mathbf{R}$ & .27 & 2.0 & 25 & $<.05$ & 5.8 & 1.5 & .85 \\
\hline & & $05 / 30 / 95$ & $\mathbf{R}$ & 1.7 & .27 & 2.3 & $<.05$ & 13 & 1.4 & 1.0 \\
\hline & & $05 / 30 / 95$ & $\mathrm{~L}$ & 1.8 & .27 & -- & $<.05$ & 13 & 1.4 & .85 \\
\hline \multirow[t]{5}{*}{44} & Big Darby Creek at & $03 / 28 / 94$ & $\mathbf{R}$ & $<.05$ & $<.05$ & .67 & $<.05$ & .13 & .07 & .08 \\
\hline & Darbyville & $03 / 28 / 94$ & $\mathrm{~L}$ & $<.05$ & $<.05$ & .63 & $<.05$ & .12 & .08 & .07 \\
\hline & & $06 / 24 / 94$ & $\mathbf{R}$ & $<.05$ & $<.05$ & .79 & $<.05$ & .79 & .18 & .15 \\
\hline & & $05 / 25 / 95$ & $\mathbf{R}$ & .18 & $<.05$ & .81 & $<.05$ & 4.1 & .44 & .30 \\
\hline & & $06 / 01 / 95$ & $\mathbf{X}$ & .10 & $<.05$ & .63 & $<.05$ & 2.2 & .28 & .22 \\
\hline \multirow[t]{3}{*}{45} & Scioto River at Higby & $04 / 06 / 94$ & $\mathbf{R}$ & $<.05$ & $<.05$ & .71 & $<.05$ & .27 & .06 & $<.05$ \\
\hline & & $07 / 01 / 94$ & $\mathbf{R}$ & $<.05$ & .35 & 6.2 & $<.05$ & 3.7 & .94 & .53 \\
\hline & & $05 / 26 / 95$ & $\mathbf{R}$ & 1.2 & .37 & 1.2 & $<.05$ & 8.5 & .68 & .54 \\
\hline \multirow[t]{4}{*}{46} & Little Miami River near & $03 / 29 / 94$ & $\mathbf{R}$ & $<.05$ & .07 & 1.3 & $<.05$ & .17 & .11 & .10 \\
\hline & Oldtown & $06 / 29 / 94$ & $\mathbf{R}$ & $<.05$ & .13 & 3.6 & $<.05$ & 2.3 & .47 & .36 \\
\hline & & $05 / 30 / 95$ & B & .32 & .12 & 2.4 & $<.05$ & 3.3 & .48 & .35 \\
\hline & & $05 / 30 / 95$ & $\mathbf{R}$ & .33 & .13 & 2.9 & $<.05$ & 3.5 & .49 & .33 \\
\hline \multirow[t]{3}{*}{47} & Mad River at Eagle City & $03 / 29 / 94$ & $\mathbf{R}$ & $<.05$ & $<.05$ & .77 & $<.05$ & $<.05$ & $<.05$ & $<.05$ \\
\hline & & $06 / 29 / 94$ & $\mathbf{R}$ & $<.05$ & .90 & 8.0 & $<.05$ & 4.5 & 1.4 & .61 \\
\hline & & $05 / 30 / 95$ & $\mathbf{R}$ & .09 & $<.05$ & .92 & $<.05$ & 1.8 & .18 & .14 \\
\hline \multirow[t]{3}{*}{48} & Tiffin River at Stryker & $03 / 30 / 94$ & $\mathbf{R}$ & $<.05$ & .05 & 2.7 & $<.05$ & .23 & .12 & .10 \\
\hline & & $06 / 28 / 94$ & $\mathbf{R}$ & $<.05$ & .38 & 10 & $<.05$ & 3.3 & 1.3 & .72 \\
\hline & & $05 / 31 / 95$ & $\mathbf{R}$ & .84 & .70 & 3.1 & .08 & 6.0 & .47 & .42 \\
\hline \multirow[t]{5}{*}{49} & Auglaize River near Fort & $03 / 30 / 94$ & $\mathbf{R}$ & $<.05$ & $<.05$ & 1.3 & $<.05$ & .11 & $<.05$ & .07 \\
\hline & Jennings & $03 / 30 / 94$ & B & $<.05$ & $<.05$ & 1.4 & $<.05$ & .12 & .05 & .06 \\
\hline & & $06 / 28 / 94$ & B & $<.05$ & 1.4 & 19 & $<.05$ & 4.9 & 1.5 & .78 \\
\hline & & $06 / 28 / 94$ & $\mathbf{R}$ & $<.05$ & 1.3 & 28 & $<.05$ & 4.8 & 1.5 & .74 \\
\hline & & $05 / 31 / 95$ & $\mathbf{R}$ & .26 & .60 & 4.4 & $<.05$ & 4.0 & .42 & .33 \\
\hline
\end{tabular}


samples from 53 streams in nine Midwestern States, 1994-95-Continued

Concentration, in micrograms per liter

\begin{tabular}{|c|c|c|c|c|c|c|c|c|c|c|c|}
\hline $\begin{array}{c}\text { Map } \\
\text { no. } \\
\text { (fig. 1) }\end{array}$ & $\begin{array}{l}\text { Cyana- } \\
\text { zine }\end{array}$ & $\begin{array}{l}\text { Cyana- } \\
\text { zine } \\
\text { amide }\end{array}$ & $\begin{array}{l}\text { De- } \\
\text { ethyl- } \\
\text { cyana- } \\
\text { zine }\end{array}$ & $\begin{array}{l}\text { De- } \\
\text { ethyl- } \\
\text { cyana- } \\
\text { zine }\end{array}$ & $\begin{array}{l}\text { Meto- } \\
\text { lachlor }\end{array}$ & $\begin{array}{l}\text { Metri- } \\
\text { buzin }\end{array}$ & $\begin{array}{c}\text { Prome- } \\
\text { ton }\end{array}$ & $\begin{array}{l}\text { Prome- } \\
\text { tryn }\end{array}$ & $\begin{array}{l}\text { Propa- } \\
\text { chlor }\end{array}$ & $\begin{array}{l}\text { Propa- } \\
\text { zine }\end{array}$ & $\begin{array}{c}\text { Sima- } \\
\text { zine }\end{array}$ \\
\hline \multirow[t]{4}{*}{43} & $<0.05$ & 0.06 & $<0.05$ & $<0.50$ & 0.18 & $<0.05$ & $<0.05$ & $<0.05$ & -- & $<0.05$ & $<0.05$ \\
\hline & 1.6 & 1.5 & $<.05$ & $<.50$ & 3.9 & .30 & $<.05$ & $<.05$ & -- & .06 & .45 \\
\hline & 11 & 3.4 & -- & -- & 5.0 & .25 & .06 & $<.05$ & $<0.05$ & .09 & .72 \\
\hline & 11 & 3.8 & -- & -- & 5.7 & .26 & .06 & $<.05$ & $<.05$ & .10 & .69 \\
\hline \multirow[t]{5}{*}{44} & $<.05$ & .06 & $<.05$ & $<.50$ & .06 & $<.05$ & $<.05$ & $<.05$ & -- & $<.05$ & $<.05$ \\
\hline & $<.05$ & .06 & $<.05$ & $<.50$ & .05 & $<.05$ & $<.05$ & $<.05$ & -- & $<.05$ & $<.05$ \\
\hline & 1.0 & .56 & $<.05$ & $<.50$ & .34 & $<.05$ & $<.05$ & $<.05$ & -- & $<.05$ & .05 \\
\hline & 2.3 & .91 & -- & -- & 1.1 & $<.05$ & $<.05$ & $<.05$ & $<.05$ & $<.05$ & .23 \\
\hline & 1.5 & .82 & -- & -- & .67 & $<.05$ & $<.05$ & $<.05$ & $<.05$ & $<.05$ & .14 \\
\hline \multirow[t]{3}{*}{45} & $<.05$ & $<.05$ & $<.05$ & $<.50$ & .22 & $<.05$ & $<.05$ & $<.05$ & -- & $<.05$ & $<.05$ \\
\hline & .97 & 1.0 & $<.05$ & $<.50$ & 2.7 & .13 & .07 & $<.05$ & -- & $<.05$ & .34 \\
\hline & 6.2 & 1.3 & -- & -- & 3.4 & .17 & .09 & $<.05$ & $<.05$ & .07 & .74 \\
\hline \multirow[t]{4}{*}{46} & $<.05$ & .07 & $<.05$ & $<.50$ & .31 & .09 & $<.05$ & $<.05$ & -- & $<.05$ & .16 \\
\hline & 2.7 & 1.6 & $<.05$ & $<.50$ & 1.2 & .16 & $<.05$ & $<.05$ & -- & $<.05$ & .40 \\
\hline & 3.0 & .95 & -- & -- & 1.0 & .06 & $<.05$ & $<.05$ & $<.05$ & $<.05$ & .12 \\
\hline & 3.2 & 1.2 & -- & -- & 1.0 & .06 & $<.05$ & $<.05$ & $<.05$ & .05 & .13 \\
\hline \multirow[t]{3}{*}{47} & $<.05$ & $<.05$ & $<.05$ & $<.50$ & .05 & $<.05$ & $<.05$ & $<.05$ & -- & $<.05$ & $<.05$ \\
\hline & .75 & .76 & $<.05$ & $<.50$ & 3.0 & .32 & $<.05$ & $<.05$ & -- & $<.05$ & .28 \\
\hline & 1.4 & .59 & -- & -- & .64 & $<.05$ & $<.05$ & $<.05$ & $<.05$ & $<.05$ & .12 \\
\hline \multirow[t]{3}{*}{48} & $<.05$ & .10 & $<.05$ & .27 & .07 & $<.05$ & $<.05$ & $<.05$ & -- & $<.05$ & $<.05$ \\
\hline & 2.4 & 3.2 & $<.05$ & $<.50$ & 1.4 & .22 & $<.05$ & $<.05$ & -- & $<.05$ & .19 \\
\hline & 6.6 & 1.8 & -- & -- & 1.7 & .30 & .12 & .06 & $<.05$ & .06 & .18 \\
\hline \multirow[t]{5}{*}{49} & $<.05$ & .05 & $<.05$ & $<.50$ & .13 & $<.05$ & $<.05$ & $<.05$ & -- & $<.05$ & .06 \\
\hline & $<.05$ & .05 & $<.05$ & $<.50$ & .14 & $<.05$ & $<.05$ & $<.05$ & -- & $<.05$ & .06 \\
\hline & .68 & -- & -- & -- & 3.7 & .81 & $<.05$ & $<.05$ & -- & $<.05$ & .41 \\
\hline & .83 & .75 & $<.05$ & $<.50$ & 4.1 & .85 & $<.05$ & $<.05$ & -- & $<.05$ & .46 \\
\hline & 3.1 & 1.3 & -- & -- & 2.5 & .26 & .14 & $<.05$ & $<.05$ & .05 & .43 \\
\hline
\end{tabular}


Table 6. Analytical results for selected herbicides and six metabolites in water

\begin{tabular}{|c|c|c|c|c|c|c|c|c|c|c|}
\hline \multirow[b]{2}{*}{$\begin{array}{c}\text { Map } \\
\text { no. } \\
\text { (fig. 1) }\end{array}$} & \multirow[b]{2}{*}{ Site name } & \multirow[b]{2}{*}{$\begin{array}{c}\text { Date of } \\
\text { collec- } \\
\text { tion } \\
\text { (month/ } \\
\text { dayl } \\
\text { year) }\end{array}$} & \multirow[b]{2}{*}{$\begin{array}{c}\text { Sam- } \\
\text { ple } \\
\text { type }\end{array}$} & \multirow[b]{2}{*}{$\begin{array}{l}\text { Aceto- } \\
\text { chlor }\end{array}$} & \multicolumn{6}{|c|}{ Concentration, in micrograms per liter } \\
\hline & & & & & $\begin{array}{l}\text { Ala- } \\
\text { chlor }\end{array}$ & $\begin{array}{l}\text { Ala- } \\
\text { chlor } \\
\text { ethane } \\
\text { sul- } \\
\text { fonic } \\
\text { acid }\end{array}$ & $\begin{array}{c}\text { Ame- } \\
\text { tryn }\end{array}$ & $\begin{array}{l}\text { Atra- } \\
\text { zine }\end{array}$ & $\begin{array}{l}\text { De- } \\
\text { ethyl- } \\
\text { atra- } \\
\text { zine }\end{array}$ & $\begin{array}{c}\text { Deiso- } \\
\text { propyl- } \\
\text { atra- } \\
\text { zine }\end{array}$ \\
\hline & & & & & & & & & & Wisconsin \\
\hline \multirow[t]{3}{*}{50} & Root River at Racine & $04 / 15 / 94$ & $\mathbf{R}$ & $<0.05$ & $<0.05$ & 0.73 & $<0.05$ & $<0.05$ & $<0.05$ & $<0.05$ \\
\hline & & $06 / 24 / 94$ & $\mathbf{R}$ & $<.05$ & $<.05$ & .84 & $<.05$ & .26 & .07 & $<.05$ \\
\hline & & $05 / 25 / 95$ & $\mathbf{R}$ & $<.05$ & $<.05$ & 1.3 & $<.05$ & .10 & .05 & .08 \\
\hline \multirow[t]{3}{*}{51} & St. Croix River at St. Croix & $04 / 13 / 94$ & $\mathbf{R}$ & $<.05$ & $<.05$ & .11 & $<.05$ & $<.05$ & $<.05$ & $<.05$ \\
\hline & Falls & $06 / 20 / 94$ & $\mathbf{R}$ & $<.05$ & $<.05$ & .10 & $<.05$ & .13 & $<.05$ & $<.05$ \\
\hline & & $06 / 12 / 95$ & $\mathbf{R}$ & $<.05$ & $<.05$ & .12 & $<.05$ & .24 & $<.05$ & $<.05$ \\
\hline \multirow[t]{3}{*}{52} & Wisconsin River at Muscoda & $03 / 21 / 94$ & $\mathbf{R}$ & $<.05$ & $<.05$ & .43 & $<.05$ & .10 & $<.05$ & $<.05$ \\
\hline & & $06 / 28 / 94$ & $\mathbf{R}$ & $<.05$ & $<.05$ & .48 & $<.05$ & .06 & $<.05$ & $<.05$ \\
\hline & & $05 / 30 / 95$ & $\mathbf{R}$ & .23 & .06 & .41 & $<.05$ & .24 & .05 & $<.05$ \\
\hline \multirow[t]{4}{*}{53} & Rock River at Afton & $04 / 06 / 94$ & $\mathbf{R}$ & $<.05$ & $<.05$ & 1.6 & $<.05$ & .07 & .07 & $<.05$ \\
\hline & & $04 / 06 / 94$ & $\mathbf{L}$ & $<.05$ & $<.05$ & 1.5 & $<.05$ & .09 & .10 & .08 \\
\hline & & $06 / 30 / 94$ & $\mathbf{R}$ & $<.05$ & $<.05$ & .97 & $<.05$ & .05 & .06 & $<.05$ \\
\hline & & $06 / 08 / 95$ & $\mathbf{R}$ & .05 & $<.05$ & 1.2 & $<.05$ & .31 & .13 & .05 \\
\hline
\end{tabular}


samples from 53 streams in nine Midwestern States, 1994-95-Continued

Concentration, in micrograms per liter

\begin{tabular}{|c|c|c|c|c|c|c|c|c|c|c|c|}
\hline $\begin{array}{c}\text { Map } \\
\text { no. } \\
\text { (fig. 1) }\end{array}$ & $\begin{array}{l}\text { Cyana- } \\
\text { zine }\end{array}$ & $\begin{array}{l}\text { Cyana- } \\
\text { zine } \\
\text { amide }\end{array}$ & $\begin{array}{l}\text { De- } \\
\text { ethyl- } \\
\text { cyana- } \\
\text { zine }\end{array}$ & $\begin{array}{l}\text { De- } \\
\text { ethyl- } \\
\text { cyana- } \\
\text { zine }\end{array}$ & $\begin{array}{l}\text { Meto- } \\
\text { lachlor }\end{array}$ & $\begin{array}{l}\text { Metri- } \\
\text { buzin }\end{array}$ & $\begin{array}{c}\text { Prome- } \\
\text { ton }\end{array}$ & $\begin{array}{c}\text { Prome- } \\
\text { tryn }\end{array}$ & $\begin{array}{l}\text { Propa- } \\
\text { chlor }\end{array}$ & $\begin{array}{l}\text { Propa- } \\
\text { zine }\end{array}$ & $\begin{array}{c}\text { Sima- } \\
\text { zine }\end{array}$ \\
\hline \multirow[t]{3}{*}{50} & $<0.05$ & 0.06 & $<0.05$ & $<0.50$ & $<0.05$ & $<0.05$ & $<0.05$ & $<0.05$ & -- & $<0.05$ & $<0.05$ \\
\hline & .27 & .12 & $<.05$ & $<.50$ & $<.05$ & $<.05$ & $<.05$ & $<.05$ & -. & $<.05$ & $<.05$ \\
\hline & .18 & .07 & -- & -- & .10 & $<.05$ & $<.05$ & $<.05$ & $<0.05$ & $<.05$ & .11 \\
\hline \multirow[t]{3}{*}{51} & $<.05$ & $<.05$ & $<.05$ & $<.50$ & $<.05$ & $<.05$ & $<.05$ & $<.05$ & -- & $<.05$ & $<.05$ \\
\hline & $<.05$ & $<.05$ & $<.05$ & $<.50$ & $<.05$ & $<.05$ & $<.05$ & $<.05$ & -- & $<.05$ & $<.05$ \\
\hline & $<.05$ & $<.05$ & -- & -- & .16 & $<.05$ & $<.05$ & $<.05$ & $<.05$ & $<.05$ & $<.05$ \\
\hline \multirow[t]{3}{*}{52} & $<.05$ & .05 & $<.05$ & $<.50$ & $<.05$ & $<.05$ & $<.05$ & $<.05$ & - & $<.05$ & $<.05$ \\
\hline & .12 & .18 & $<.05$ & $<.50$ & .10 & $<.05$ & $<.05$ & $<.05$ & -- & $<.05$ & $<.05$ \\
\hline & .49 & $<.05$ & -- & -- & .52 & $<.05$ & $<.05$ & $<.05$ & $<.05$ & $<.05$ & $<.05$ \\
\hline \multirow[t]{4}{*}{53} & $<.05$ & .08 & $<.05$ & $<.50$ & $<.05$ & $<.05$ & $<.05$ & $<.05$ & -- & $<.05$ & $<.05$ \\
\hline & .06 & .08 & $<.05$ & $<.50$ & $<.05$ & $<.05$ & $<.05$ & $<.05$ & -. & $<.05$ & $<.05$ \\
\hline & .14 & .12 & $<.05$ & $<.50$ & $<.05$ & $<.05$ & $<.05$ & $<.05$ & -- & $<.05$ & $<.05$ \\
\hline & .27 & .09 & -- & -- & .18 & $<.05$ & $<.05$ & $<.05$ & $<.05$ & $<.05$ & $<.05$ \\
\hline
\end{tabular}




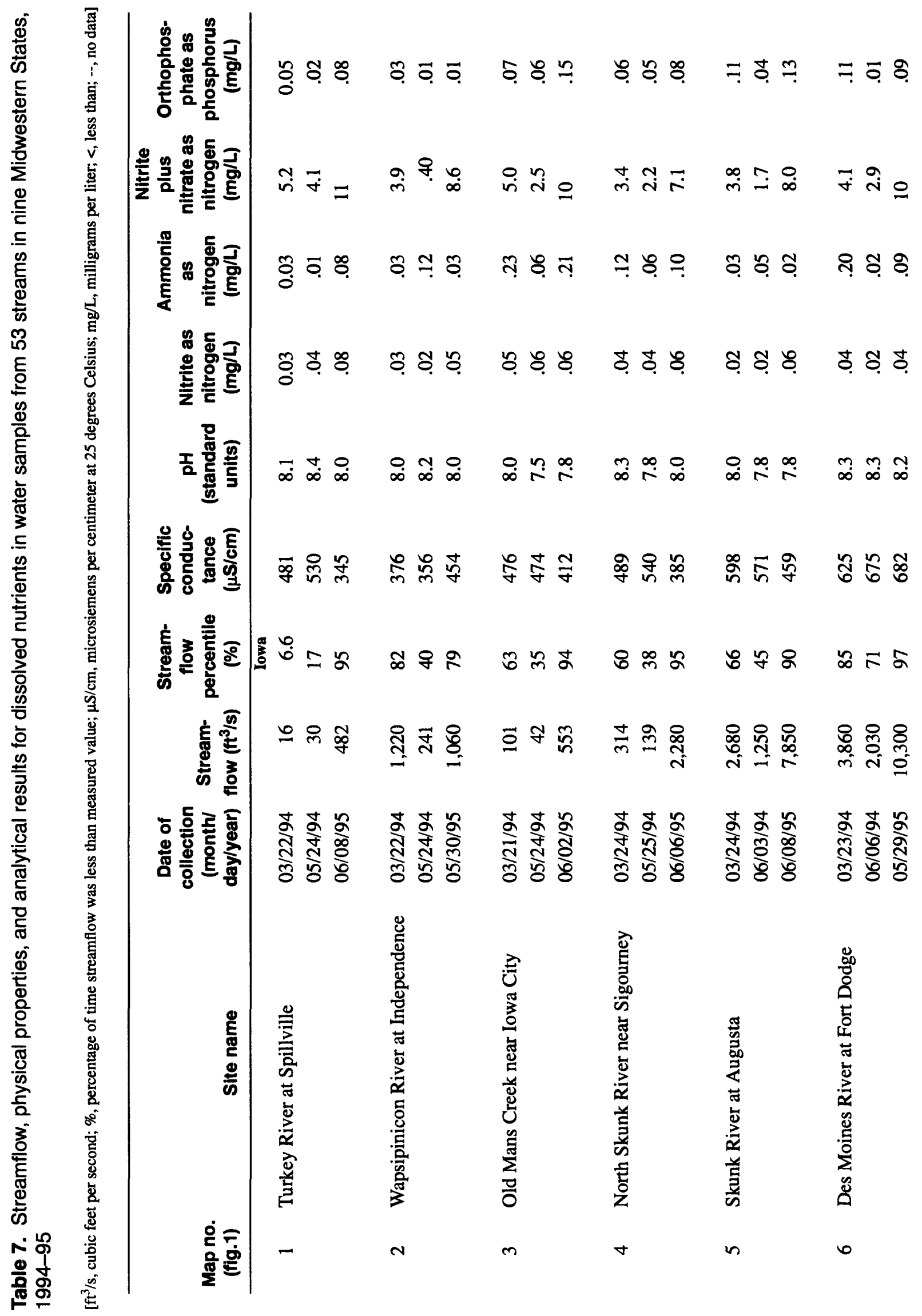




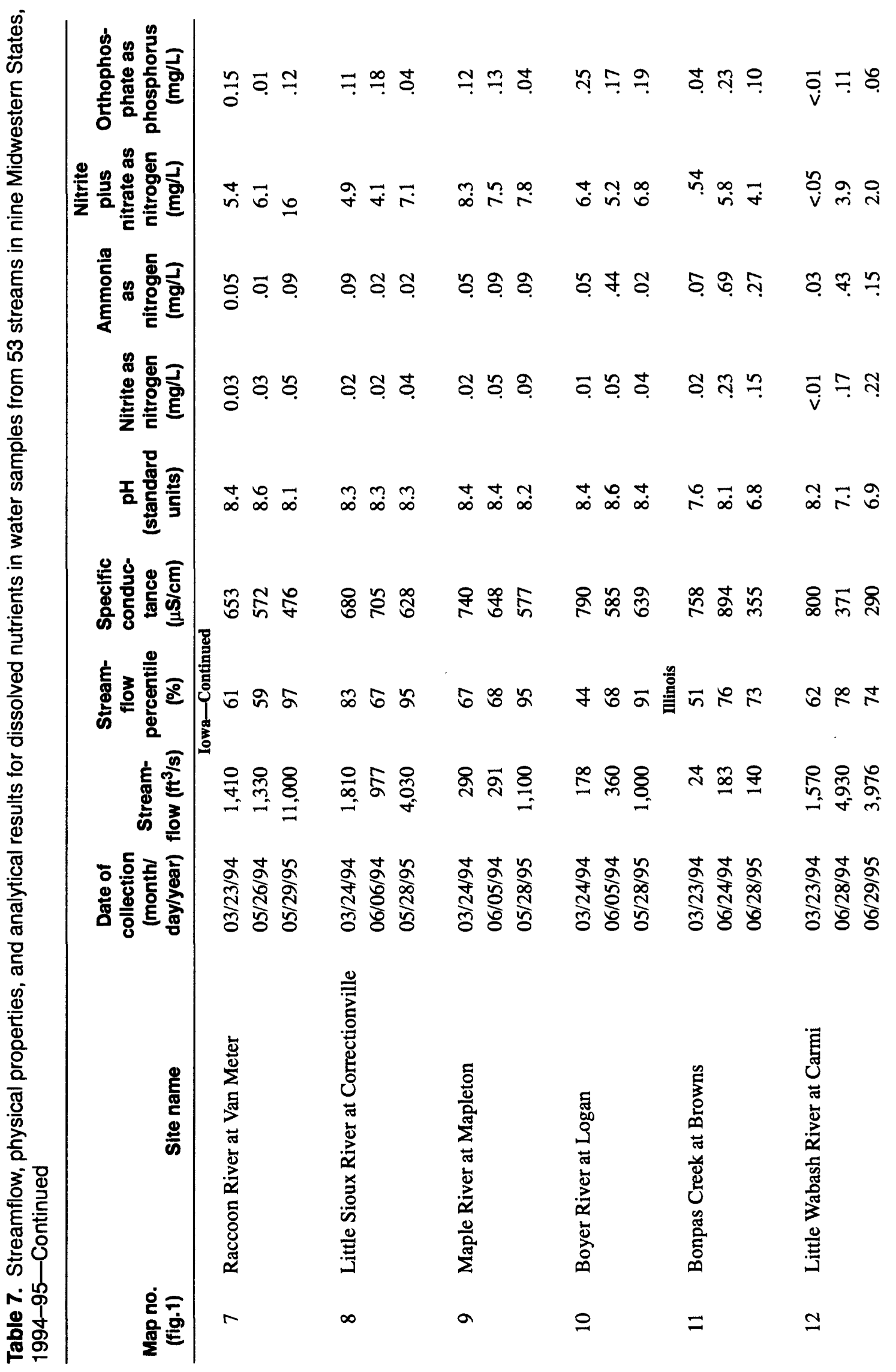




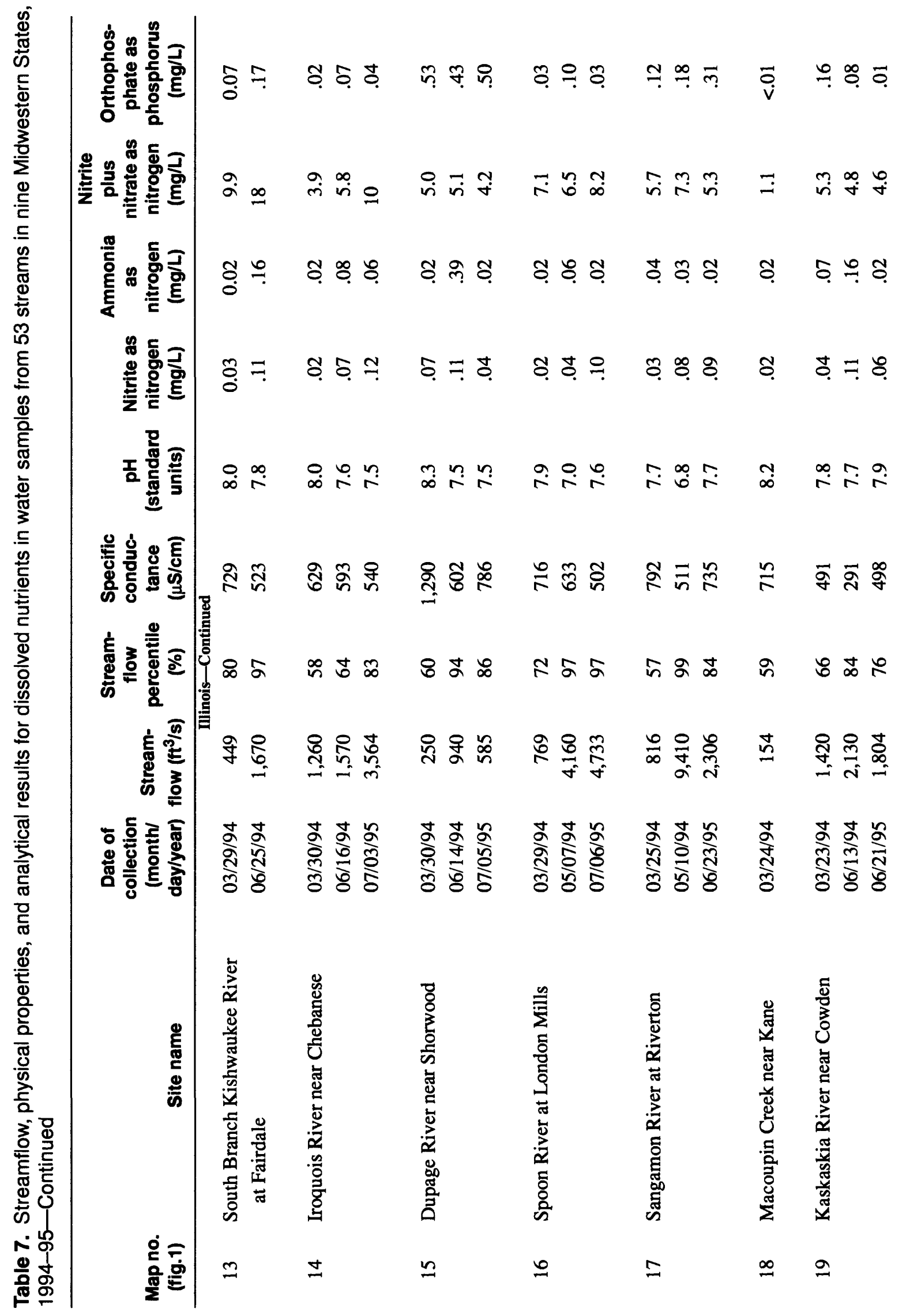




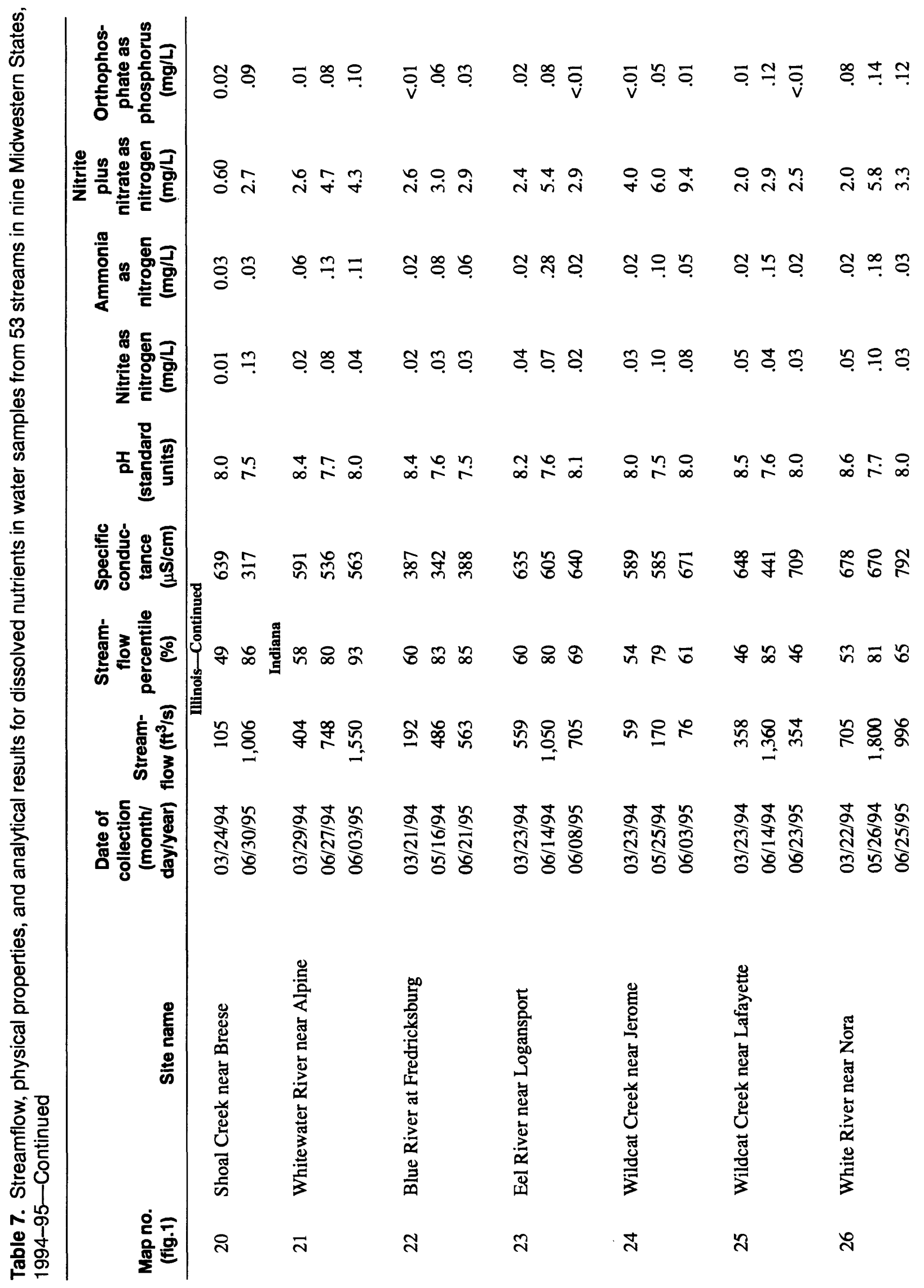




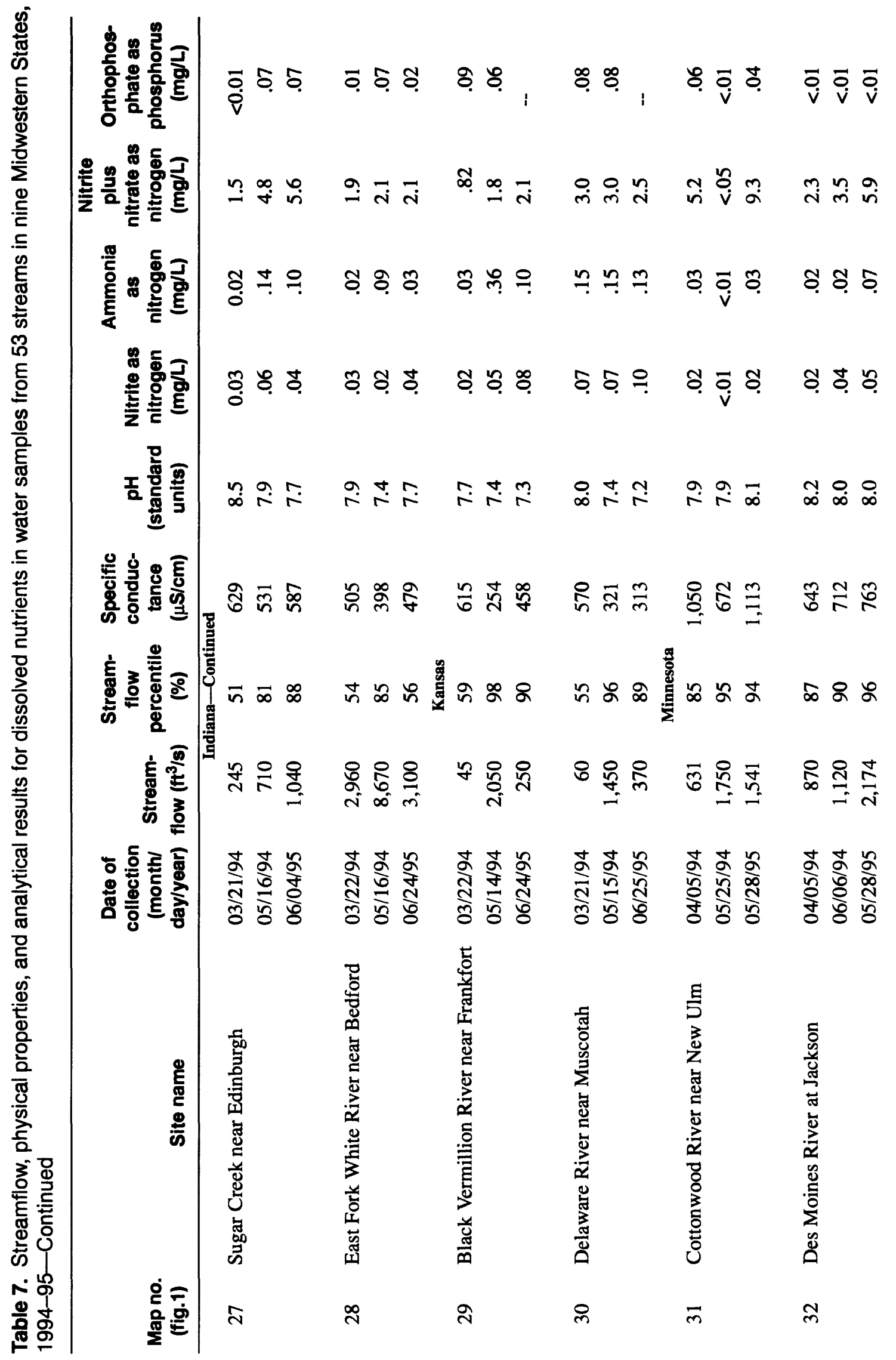




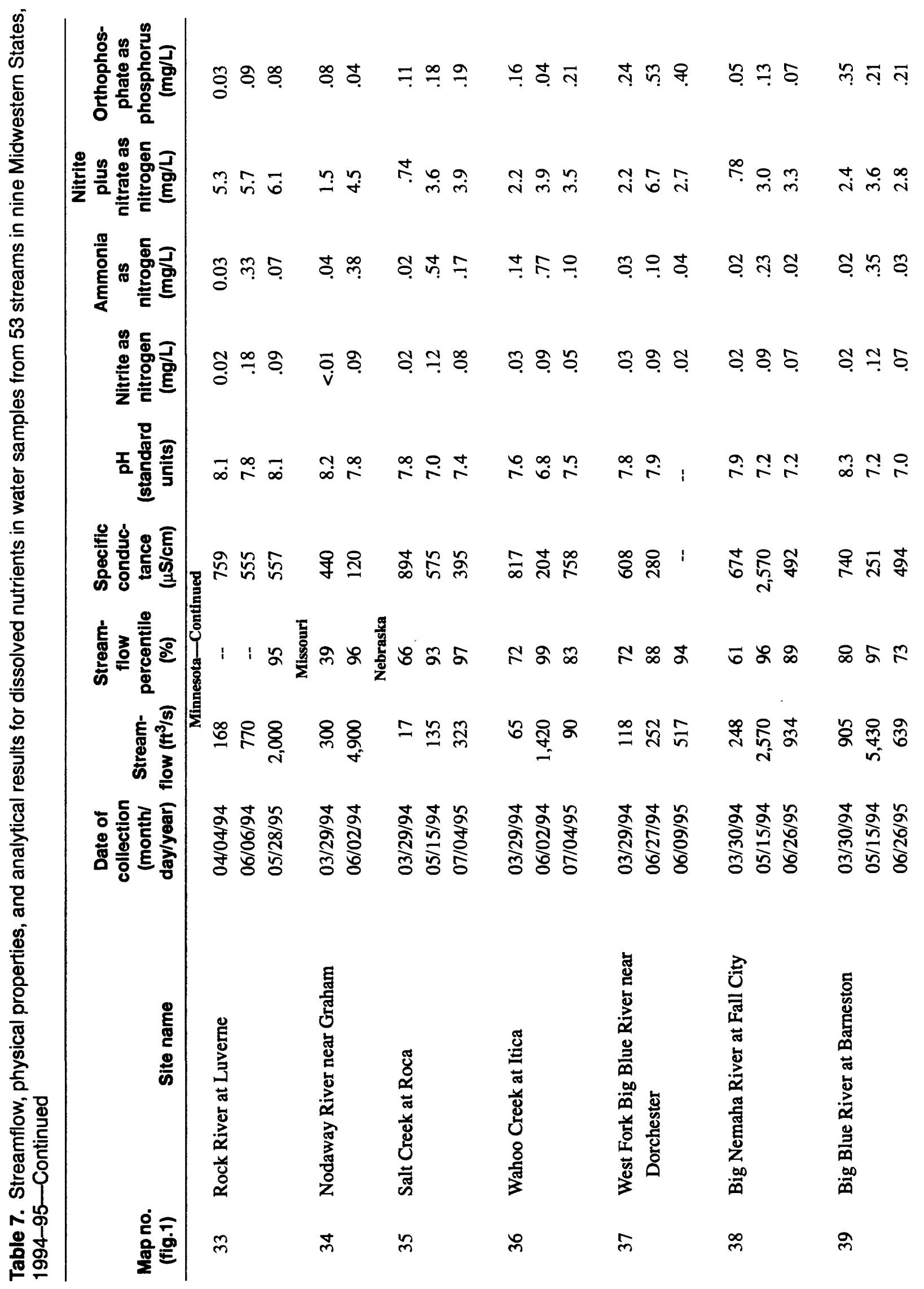




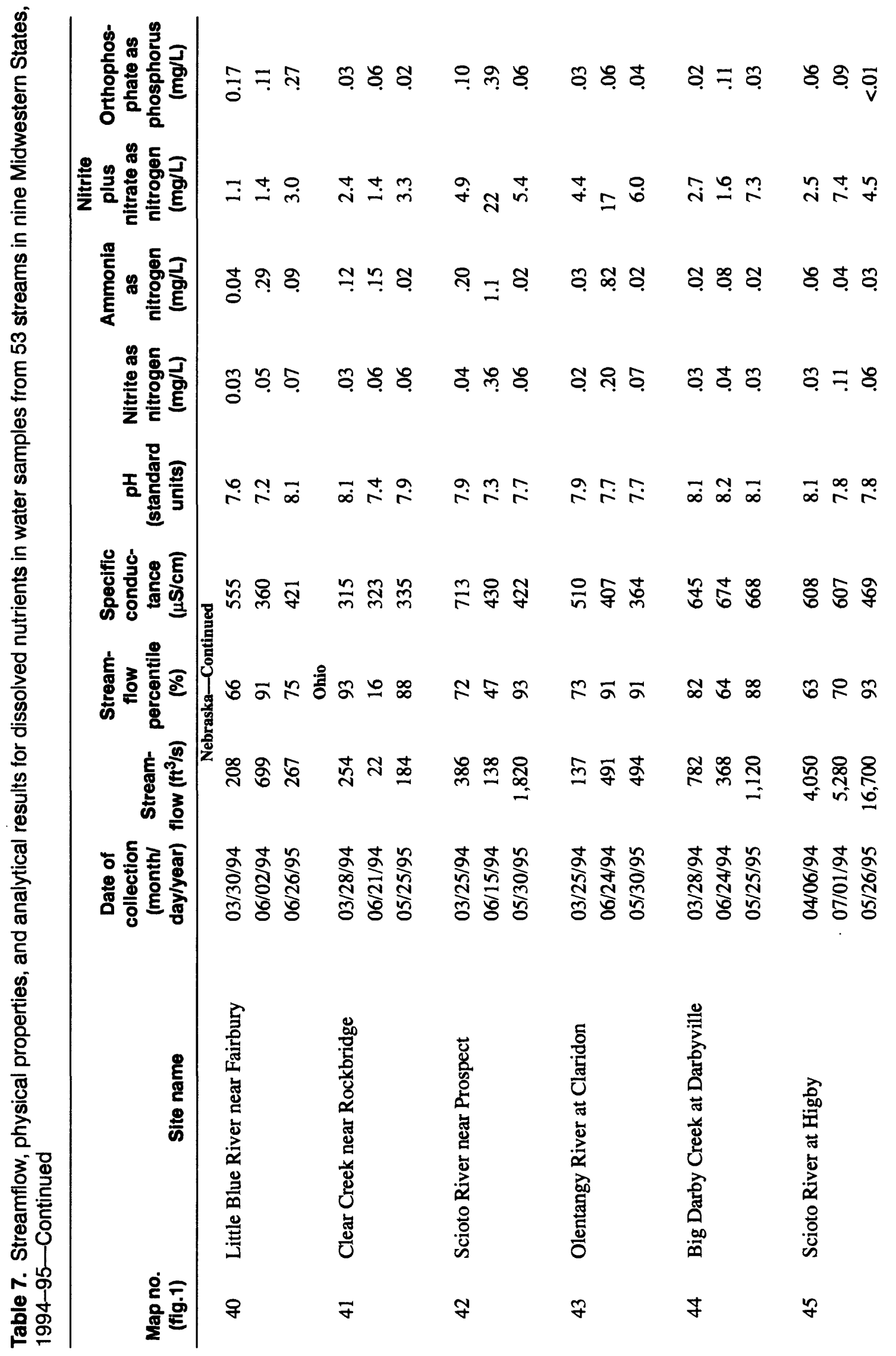




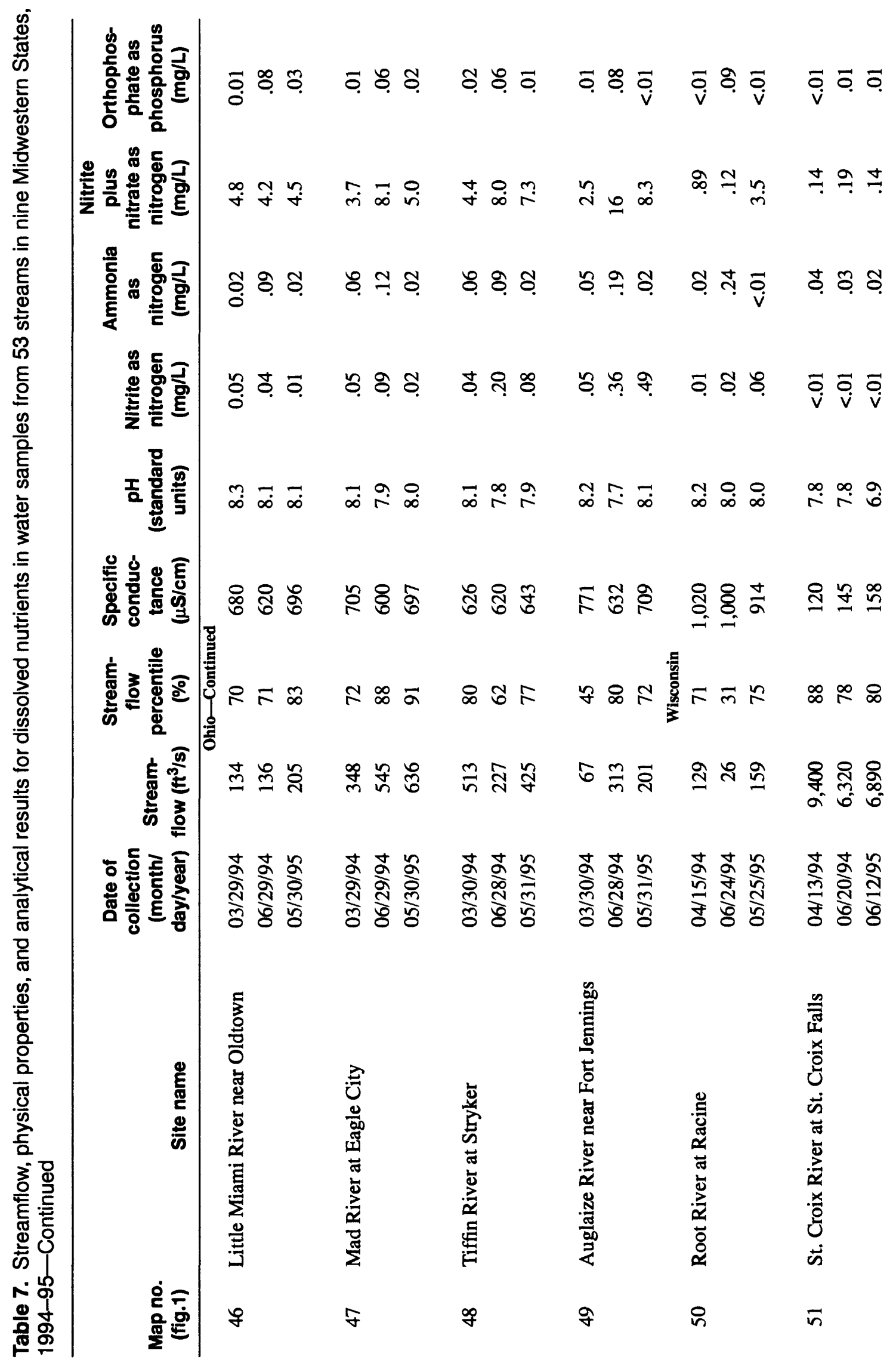




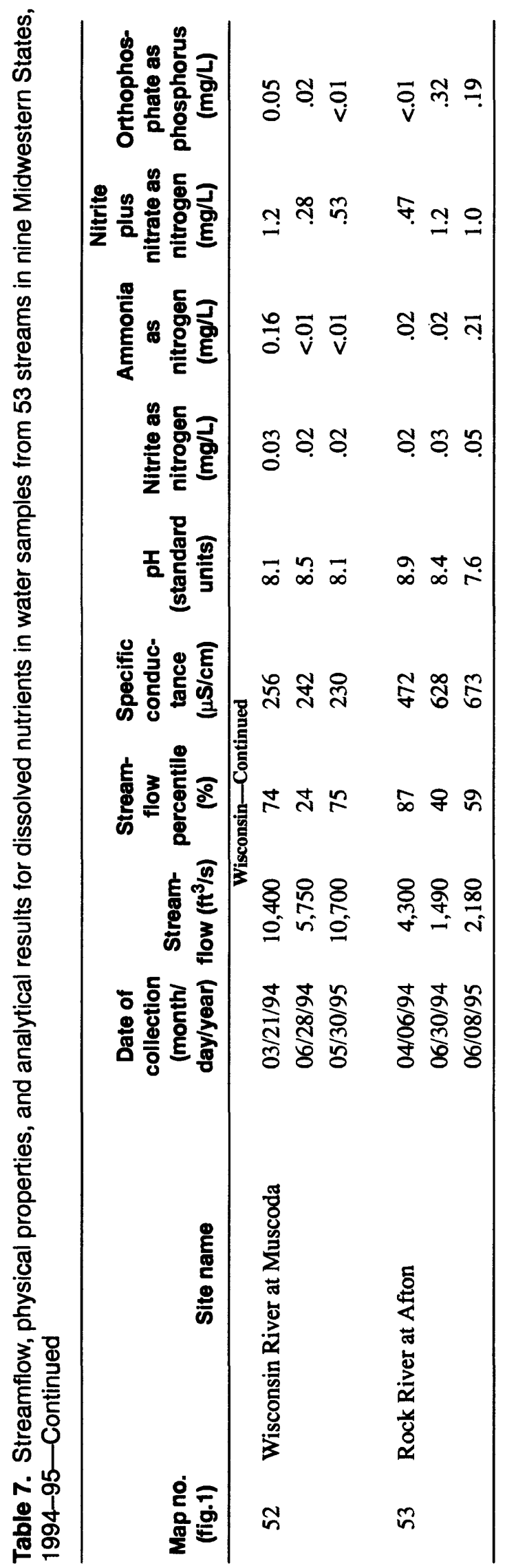

